Rhode Island College

Digital Commons @ RIC

\title{
The Relationship between Assistive Technology State Standards for Teachers, Assistive Technology Implementation, and Student Performance in the Context of Evidence-based Practice
}

\author{
Elizabeth M. Dalton \\ Rhode Island College
}

Follow this and additional works at: https://digitalcommons.ric.edu/etd

Part of the Educational Assessment, Evaluation, and Research Commons, Other Computer Sciences Commons, Special Education Administration Commons, and the Special Education and Teaching Commons

\section{Recommended Citation}

Dalton, Elizabeth M., "The Relationship between Assistive Technology State Standards for Teachers, Assistive Technology Implementation, and Student Performance in the Context of Evidence-based Practice" (2009). Master's Theses, Dissertations, Graduate Research and Major Papers Overview. 13. https://digitalcommons.ric.edu/etd/13

This Dissertation is brought to you for free and open access by the Master's Theses, Dissertations, Graduate Research and Major Papers at Digital Commons @ RIC. It has been accepted for inclusion in Master's Theses, Dissertations, Graduate Research and Major Papers Overview by an authorized administrator of Digital Commons @ RIC. For more information, please contact digitalcommons@ric.edu. 
THE RELATIONSHIP BETWEEN ASSISTIVE TECHNOLOGY STATE STANDARDS FOR TEACHERS, ASSISTIVE TECHNOLOGY IMPLEMENTATION, AND STUDENT PERFORMANCE IN THE CONTEXT OF EVIDENCE-BASED PRACTICE

BY ELIZABETH MINCHIN DALTON

A DISSERTATION SUBMITTED IN PARTIAL FULFILLMENT OF THE REQUIREMENTS FOR THE DEGREE OF DOCTOR OF PHILOSOPHY IN EDUCATION 


\begin{abstract}
Purpose: Consideration of assistive technology (AT) for special education students has been federally mandated since 1997. Since the 2002 No Child Left Behind Act (NCLB), rigorous evidence-based educational practices are also mandated. While national technology standards for teachers in general education exist to guide educational technology (ET), it is not clear if AT standards exist for U.S. teachers, or on what evidence standards are based. The purposes of this study, therefore, were to 1) describe three state-level regulatory elements related to AT: i) presence of formally adopted AT standards, ii) level of scientific evidence supporting those standards and iii) extent to which states offer support for teachers' implementation of AT, and 2) examine the relationship between these regulatory elements and academic performance of students in Special Education. Method: Data were collected in two ways. First, 110 literature documents were reviewed for type of standard and the nature and rigor of evidence. Secondly, data on the three regulatory elements were collected via telephone and email from the 50 State Departments of Education plus Washington DC. Multiple regression analyses compared the regulatory elements as predictor variables with national reading and math performance of special education students. Analysis/Results: Literature analysis results reveal $81 \%$ ET and $80.5 \%$ AT literature based on survey or expert opinion evidence, with standards the primary focus of $10 \%$ of AT literature. Descriptive analyses revealed nine states with stateapproved AT standards for teachers and five states with evidence supporting their standards; the rigor for this evidence was low. Forty-seven states provide information to teachers on AT, 17 states recommend professional development in AT with three
\end{abstract}


having AT endorsement or certification. Multiple regression analyses found no significant relationship between the three regulatory elements and student performance in either reading or math. Discussion: Literature and study results indicate a general lack of AT standards either documented or officially in use in education, with supporting evidence not highly rigorous or not evident. Considering NCLB, lack of evidence-based standards makes AT vulnerable to reduced priority and funding. Research documenting impact of existing AT standards and rigorous evidence of related student performance is recommended. 


\section{ACKNOWLEDGEMENTS}

In every Ph.D. students' life, there are individuals who played important roles in helping and supporting the student through the many challenges of the program and the dissertation process. I would like to recognize the following persons who have supported me along that path:

Dr. A. Anthony Antosh, Director of the Paul V. Sherlock Center on Disabilities, without whose ongoing support I could not have completed this Ph.D. in Education; Dr. Louis Heifetz, my first major advisor, who believed in me and encouraged me through a very difficult time in my life, and stuck with me to finally realize completion of my comprehensive examinations;

Dr. David Edyburn and Dr. Edmund Blackhurst, national leaders in the field of assistive technology, who took the time to read and offer feedback and encouragement on my work;

Dr. Karen Castagno, Dr. Ezra Stieglitz, and Dr. Peter Adamy, who, as my program advisors, have spent many hours and offered such helpful feedback and support during this dissertation process;

And, finally,

Dr. Susan Roush, my major advisor for this dissertation, and an amazing colleague and friend. Without Dr. Roush's constant support, clear guidance, and incredibly timely and valuable feedback throughout my dissertation journey, I truly believe that I would not have been able to successfully complete this mission. Thank you, Susan.

Thank you, all. 


\section{DEDICATION}

To my two amazing sons, John and Martin, who are the loves of my life. We have been through so much together! My boys, you have supported me, always, during this long academic journey..... I dedicate this work to you both.

and

To my dear friend and colleague, Judi Hammerlind Carlson. It is such a long time since that fateful train ride back from Washington, when assistive technology became, and continues to be, the focus of our lives..... Thank you for the many wonderful years of comradery, and for your everlasting friendship. You are part of this dissertation, my friend. 


\section{TABLE OF CONTENTS}

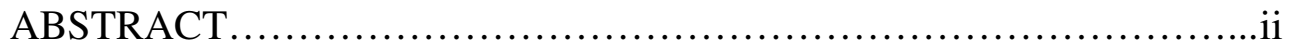

ACKNOWLEDGEMENTS ......................................... iv

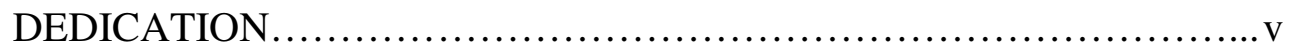

TABLE OF CONTENTS .......................................... vi

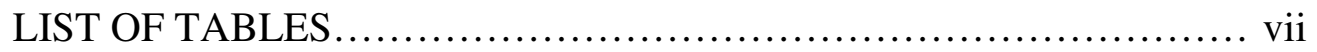

CHAPTER

$1 \quad$ Introduction........................................... 1

Significance of Study................................. 13

Literature Review and Analysis..............................

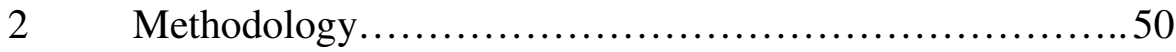

Institutional Review Board Waiver....................... 62

$3 \quad$ Results..........................................6. 63

Descriptive Analyses................................ 63

Regression Analyses................................ 73

$4 \quad$ Discussion.......................................... 78

Limitations of Study................................ 92

5 Conclusions and Recommendations.................... 95

\section{APPENDIX}

A Study Survey Form, Letter of Introduction................ 99

B Data Classification Forms............................. 105

C AT State Department of Education Contacts.............. 108

D Glossary of Terms................................ 110

BIBLIOGRAPHY .............................................. 112 


\section{LIST OF TABLES}

Table 1: Four Categories of Educational Standards.................. 20

Table 2: Hierarchies/Continuums/Types of Evidence for EBP......... 26

Table 3: Educational Technology: Evidence Classification by Type of Standard and Level of Rigor in EBP of Identified Literature..... 34

Table 4: Assistive Technology: Evidence Classification by Type of Standard and Level of Rigor in EBP of Identified Literature.... 36

Table 5: Literature by topic $(1-3$ descriptors per item)............. 42

Table 6: Educational Technology: Percentage of Evidence Found by Type of Standard and Level of Rigor in EBP within Identified Literature.

Table 7: Assistive Technology: Percentage of Evidence Found by Type of Standard and Level of Rigor in EBP within Identified Literature. 46

Table 8: Types of AT Standards Existing in US (N=6)............. 65

Table 9: Types of AT Competencies Existing in US (N=6)........... 67

Table 10: AT Implementation in the Education System - Instructions

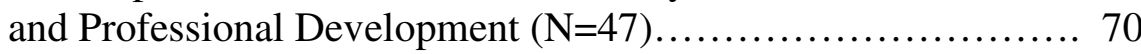

Table 11: Other State AT Implementation Activities $(\mathrm{N}=49) \ldots \ldots \ldots \ldots . . .71$

Table 12: Descriptive Results for Predictor and Criterion Variables of U.S. States $(\mathrm{N}=51)$

Table 13: Pearson Single Tailed Correlations between Predictor Summary Variables (AT Standards/Competencies, AT Implementation, and Level of Evidence) and Criterion Variables (2006 $4^{\text {th }}$ Grade Reading and Math, at or above basic proficiency).

Table 14: Model Summaries for Correlations between Predictor Variables (AT Standards/Competencies, AT Implementation, and Level of Evidence) and Criterion Variables (2006 $4^{\text {th }}$ Grade Reading and Math, at or above basic proficiency)................... 75

Table 15: Analysis of Variance (ANOVA) of Predictor Variables (a.) for Criterion Variables (b. \& c.). 


\section{CHAPTER 1}

Introduction

\section{Terminology}

The field of assistive technology, as well as other areas included in the research presented in this dissertation, uses certain terms that may not be commonly known. For the purposes of this study, these terms and their definitions appear in the Glossary of Terms in Appendix D.

\section{History and Background on AT}

Assistive technology (AT) grew to become an area of specialization in the fields of education and rehabilitation during the early 1980s, following the emergence of the personal computer in modern society (Sutton, 1991). AT, however, involves more than just computer-related technology. The legal definition of AT in the United States is "any item, piece of equipment, or product system, whether acquired commercially off the shelf, modified, or customized, that is used to increase, maintain, or improve the functional capabilities of individuals/students with disabilities" (Aleman, 1991; Association for the Advancement of Rehabilitation Research, 1998a $\&$ b). This definition includes a full range of general and specialized technology as potential AT, including both low tech (non-electronic) and high tech (electronic) solutions. The purpose of AT is to support functional access for persons with disabilities to life and its many activities. AT can potentially "level the playing field" in numerous functional and programmatic areas for persons with disabilities, however many different factors have been identified as needing to be addressed in order for this potential to be achieved (Boone \& Higgins, 2007; Crandall, Gerrey, \& Brabyn, 1994; 
Hitchcock, 2001; Hutinger, Johanson, \& Stoneburner, 1996; Lindstrand, 2001; Tindal, Heath, Hollenbeck, Almond, \& Harniss, 1998). Some of the critical factors identified as necessary for successful AT use are: (1) ease of access, (2) device transparency (when AT devices operate as if they are general technology devices), (3) appropriate device feature match to individual need, (4) flexibility of use, (5) user training, (6) user competence, and (7) user interest (Boone \& Higgins, 2007; Crandall, Gerrey, \& Brabyn, 1994; Hitchcock, 2001; Hutinger, Johanson, \& Stoneburner, 1996; Lindstrand, 2001; Tindal, Heath, Hollenbeck, Almond, \& Harniss, 1998).

Historically, the use of technology to support individuals' access to education and employment grew from issues and laws pertaining to equity and civil rights. Laws such as the Rehabilitation Act of 1973 (Rehab Act) and the Americans with Disabilities Act of 1990 (ADA) defined and strengthened the rights of persons with disabilities to gain equal access to work, independent living, public facilities, businesses, transportation, and telecommunications (U.S. Department of Justice, 2007; U.S. Department of Labor, 2007a \& 2007b). Section 503 of the Rehab Act defines the right to reasonable accommodation, "making adjustments or modifications in the work, job application process, work environment, job structure, equipment, employment practices or the way the job duties are performed so that an individual can perform the essential functions of the job" (U.S. Department of Labor, 2007a, p.2). Requirement of reasonable accommodations in federally funded programs for all otherwise qualified persons with disabilities, as described in Section 504 of the Rehab Act, drives the equity of access in our post-secondary institutions, as well as requiring Section 504 access plans for eligible students in public elementary \& secondary 
schools. Section 504 ensures that students with disabilities, who attend schools receiving federal funds, receive the accommodations necessary to gain equal access to educational facilities and programs (U.S. Department of Justice, 2007; U.S.

Department of Labor, 2007b). The ADA mirrors this same principle of equal access, but extends access to include environments beyond those of education and federally funded programs. All of these laws reference AT, and identify technology as a tool in providing individualized supports to achieve reasonable accommodations and equal access (U.S. Department of Justice, 2007; U.S. Department of Labor, 2007a \& 2007b). Unfortunately, the process for AT consideration, and the guidelines for implementation of AT in differing environments are not specifically described by these laws.

The first major U.S. legislation solely to focus on the AT needs of the community was PL 100-407, the Technology-Related Assistance Act for Individuals with Disabilities of 1988, commonly called the Tech Act. This Act provided, for the first time, the specific definitions for AT devices and AT services (Association for the Advancement of Rehabilitation Research, 2007), definitions currently used in all U.S. legislations that reference these terms. In 1990, the Education of the Handicapped Children Act (PL 101- 476) identified AT as a relevant component of programs and services for children in special education (Aleman, 1991). The 1997 Individuals with Disabilities Education Act (IDEA) went further to require that AT it be considered for every special education student during the development of their Individualized Education Program (IEP) (Schrag \& Ahearn, 1998). Research indicates that consistent and well-implemented procedures and guidelines for AT are lacking, and that such 
procedures and guidelines are needed to ensure successful AT use in education (Bell, 2001; Bell \& Blackhurst, 1996; Lenker \& Paquet, 2004).

Federal IDEA law requires schools to consider the use of AT for enhancement of functional capabilities of students, however, there is little in the law itself to specifically guide AT implementation for teachers and students (Blackhurst \& Edyburn, 2000), such as the possible requirement of specific AT standards. This lack of federal guidance on AT implementation puts individual states in the position of determining their own standards and guidelines for AT use in schools. While it can be argued that individual states may be best able to identify and integrate local needs and concerns into their educational guidelines, a lack of national standards and guidance in AT could invite variation and inconsistency in expectations and standards of performance across states. This potential variation among states is problematic, because it could violate the federal mandates that ensure consideration and subsequent minimal levels of AT implementation and services in order for all students to benefit from public education. The relationship between state-based AT standards, AT implementation, teacher competence, and student performance is not known. Research is needed in order to understand how states are addressing these mandates, what is actually working and what is not, and why such mandates are important to the success of students with disabilities.

\section{AT and Factors Influencing Student Support in Educational Settings}

There is case study research that shows that AT can effectively support and increase academic achievement of special education students in a number of educational settings (Calculator, 1999; Hutinger, Johanson, \& Stoneburner, 1996; 
Todis, 1996). Other studies, however, show that individuals' use of AT is not always positive or effective in improving performance (Johnston \& Evans, 2005; Kittel, DiMarco, \& Stewart, 2002; Light, 1999; Phillips \& Zhao, 1993; Riemer-Reiss \& Wacker, 2000). Instructor \& user competence, user choice, system support, and appropriate match of device features to user and environmental needs are factors identified as important to successful AT integration and use (Hutinger, Johanson, \& Stoneburner, 1996; Riemer-Reiss \& Wacker, 2000; Todis, 1996).

A wide range of AT devices exist that can support students' educationallyrelated functions, specifically for physical access, cognitive and learning access, communication access, and sensory access (Brown \& Cavalier, 1992; Crandall, Gerrey, \& Braybyn, 1994; Englert, Manalo, \& Zhao, 2004; Lange, McPhillips, Mulhern, \& Wylie, 2006; Lee \& Vail, 2005; MacArthur \& Cavalier, 2004; Ripat \& Strock, 2004; Williams, 2002). Some examples of AT devices commonly used by students with disabilities to participate in school settings include power wheel chairs, voice input and output software and hardware, reading and writing enhancement software, augmentative communication devices that "speak" for the non-speaking student, and visual enlargement or assistive listening devices for students with visual or hearing impairments (Brown \& Cavalier, 1992; Crandall, Gerrey, \& Braybyn, 1994; Englert, Manalo, \& Zhao, 2004; Lange, McPhillips, Mulhern, \& Wylie, 2006; Lee \& Vail, 2005; Macarthur \& Cavalier, 2004; Ripat \& Strock, 2004; Williams, 2002). Factors such as mode of access, size, connectivity, programmability, interactivity, voice options, and symbol options must be considered for the fit between device, user, and environment in the context of AT use to be positive and effective (Johnston \& 
Evans, 2005; Light, 1999; Riemer-Reiss \& Wacker, 2000). Such matching of device features to user and environmental needs, referred to as "feature matching" in the field of AT, is a critical component for AT effectiveness (Riemer-Reiss \& Wacker, 2000).

To create good contextual fit between AT device, individual, and environment, coordination between the individual's physical, cognitive, and social environments must be achieved (Johnston \& Evans, 2005). The achievement of coordination and good contextual AT fit for students with special needs requires appropriate training and experiences for teachers and related service professionals to develop necessary knowledge and skill competence in AT (Bausch \& Hasselbring, 2004).

In addition to coordination and contextual fit, a recently published review of AT literature identified several studies showing positive social outcomes for students with special needs who use AT, however, as with academic outcomes, not all experiences with AT in schools were positive (Alper \& Raharinirina, 2006). Barriers exist for effective AT use at individual, classroom, and system levels (Alper \& Raharinirina, 2006). Significant information is available concerning AT effectiveness at individual and/or classroom levels (Behrmann \& Jerome, 2002; Bowser \& Reed, 1995; Carey \& Sale, 1994; Hasselbring \& Glaser, 2000; MacArthur, Graham, Haynes, \& De La Paz, 1996; MacArthur, Haynes, Malouf, Harris, \& Owens, 1990; McInerney, Riley, \& Osher, 1999; Raskind \& Higgins, 1995). Few studies, however, examine the nature and challenges of AT implementation at state and federal levels of education. In available studies of state and federal AT implementation, the following needs are identified: (1) development of AT policies by states to guide delivery of AT services; (2) teacher and team training to guide AT choice-making; and (3) flexibility of 
program design that responds to growing needs and changing technology (Bell, 2001;

Bell \& Blackhurst, 2996; Lahm \& Nickels, 1999; Peterson, 1998). No specific studies were found that explore the relationship between state policies and implementation of AT, AT teacher competence, and student success. The relationship between AT and student performance lacks verification beyond the individual (case study) level. Standards, AT Competencies, Performance, and Evidence-based Practice

Currently, in U.S. education, there is much concern about and focus on the relatively poor academic performance of U.S. students, when compared with students in other developed countries, as well as when making comparisons amongst students of different socio-economic and disadvantaged groups (U.S. Department of Education, 2007b). The U.S. system of education, in response to this concern, requires and is working to establish nationally implemented standards in all states for K-12 academic performance in numerous content areas, as part of the No Child Left Behind Act (NCLB) (U.S. Department of Education, 2007b). All states must now conduct and report annual student performance assessments, and states must demonstrate achievement of adequate yearly progress for all students, including students with disabilities. When adequate yearly progress is not achieved, districts and states must initiate corrective procedures (U.S. Department of Education, 2007c). Implementation of the requirements of NCLB for students with disabilities is controversial; some sources claim that the NCLB expectations for these students are unreasonable and possibly discriminatory (National Association of Elementary School Principals, 2007; Samuels, 2007) while other sources claim that NCLB expectations for students in special education positively affect student learning and achievement (Jewell, 2007). 
These experts believe that students are best served by a system with equal standards and expectations for all, including students with disabilities, expecting reasonable accommodations and suitable academic supports, including assistive technologies, will provide equal access to learning (Jewell, 2007). The full impact of NCLB on the performance of students with disabilities is still to be determined, however the requirement of performance standards for all students is solidly in place, along with required standards of performance for highly qualified teachers (U.S. Department of Education, 2006). Working toward the achievement of academic standards is now part of the daily classroom reality for teachers and students in both general and special education, and appropriate supports for students with disabilities are part of this equation.

While NCLB holds special education students to high academic standards, and the use of AT to accommodate students with disabilities can help them in striving for these high standards, comprehensive standards for AT use that are fully accepted in the U.S. educational system do not yet exist. Without such standards, comprehensive and equitable guidelines to integrate AT into the general educational system cannot be developed. Fortunately, however, certain AT standards and guidelines do exist with special education's learned community, the Council for Exceptional Children (CEC) and their standards for special education technology specialists (Council for Exceptional Children, 2003). The professions of occupational therapy (OT) and speech-language pathology (SLP) also have their own specific sets of AT standards (Hammel \& Angelo, 1996; American Speech-Language-Hearing Association, 1997). The National Association of State Special Education Directors have also identified AT 
standards for teachers (Bell, 2001). None of these sets of AT standards, however, have been accepted or implemented nationally.

National standards, by comparison, do exist in general education for the use of educational technology in schools by students, teachers and administrators (International Society for Technology in Education, 2007). However, inclusive, nation-wide standards to guide both general and special education teachers' use of AT in K-12 classrooms are not yet available. States, therefore, must develop AT standards or competencies for use in general and special education classrooms according to their own priorities and processes, or adopt existing professional standards that meet their priorities and needs.

Interestingly, in the field of AT, there are differing views and conflicting information about the meaning of the term standards, the nature of different types of standards and competencies, the existing AT standards in the U.S., and the evidence on which existing standards are based (Bausch \& Hasselbring, 2004; Bell \& Blackhurst, 1996; California Department of Education, 2006; Campbell, 2000; Chen, Wu, \& Chu, 2004; Council for Exceptional Children, 2003; Nickels, 1999; Weber, 1998; Zabala, Blunt, Carl, Davis, Deterding, Foss, et al., 2000). The field shows that many studies have been conducted concerning the knowledge and skills needed by teachers to use AT (Bausch \& Hasselbring, 2004; Lahm, 2003; Lahm \& Sizemore, 2002; Maushak, Kelley, \& Blodgett, 2001; Michaels \& McDermott, 2003; Parette, 1997; Riley, Beard, \& Strain, 2004; Sax, Fisher, \& Pumpian, 1996; Todis, 1996; Warger, 1998). Few studies, however, document existence or implementation of AT standards (Edyburn, 2002; McNear, 2005; QIAT Consortium Leadership Team, 2000) 
or document how the standards were established (Odom, Brantlinger, Gersten, Horner, Thompson, \& Harris, 2005; Paulsen, 2005; Schlosser \& Raghavendra, 2004). With the pressures of current federal educational legislation requiring that curriculum and intervention approaches be research and evidence-based (U.S. Department of Education, 2006, 2007a \& b), development of a strong research foundation between AT, education, and EBP is necessary. First, however, the nature of evidence in relation to AT standards needs to be determined.

\section{Indicators of AT Implementation and Student Performance}

In the United States, implementation of guidelines for the use of AT in the educational system, as previously stated in History and Background of AT, is the responsibility of the individual states. State departments of education appear to approach the implementation of AT in different ways. On the Internet, some states, such as Maryland and Indiana, report having standards for the use of AT by teachers and by students (Pierce, 2006; Ryan, 2007). Other states identify guidelines for using AT in school environments or in statewide assessments (Minnesota Department of Education, 2005; North Dakota Department of Public Instruction, 1999). Certain states, e.g. Connecticut, outline procedures for AT integration in IEPs (Connecticut Department of Education, 2007). Studies of the overall status of AT implementation across all states, however, and its relationship to the academic performance of students with disabilities are scarce. One study (Bell, 2001) found that $92 \%$ of all respondents from the 50 U.S. state departments of education identified a great need for state AT policies to guide delivery of services to school districts. In this same study, $86 \%$ of respondents identified a moderate to great need for state and local AT policies. Aside 
from Bell, comprehensive studies of the nature of current AT standards and guidelines in education or of the relationship between AT standards and student performance do not appear in the literature.

There are many different measures of student academic performance in use today, some at local levels and some at state levels. The NCLB data currently required of all states include standardized statewide assessment of reading and mathematics (U.S. Department of Education, 2007b). The U.S. Department of Education mandates that states report performance scores in these areas for all students attending public schools. Reports must contain aggregated and disaggregated scores for all federally targeted groups (U.S. Department of Education, 2007b). Students with disabilities, specifically those who have IEPs, are one of these groups. It is now possible to identify the academic performance of students with disabilities, using these measures, across the 50 United States. The relationships among AT standards, evidence used to establish AT standards, AT implementation, and student performance are not yet known. Identification of relationships among these factors, and determination of possible predictive ability among factors, would add greatly to the research base in the field of AT, as well as to the scope of research in this area in the field of education.

\section{Purpose of the Study}

The purpose of this study is to examine the relationship between the three factors of AT standards, levels of evidence, and AT implementation to the measured reading and mathematics performance of special education students in the United States. This study will: 
(1) Identify the types of AT standards and/or competencies currently in use, if any, at each of the US state educational departments at the K-12 level

(2) Identify evidence used to establish AT standards and/or competencies, and identify level of evidence rigor

(3) Identify system indicators of implementation of AT policies

(4) Analyze the relationship of types of standards \& competencies, evidence rigor, and implementation level with the academic performance of special education students, according to specific national measures.

The study will gather data using the following: (a) state education department websites, (b) author-designed questionnaires electronically distributed to state department AT coordinators (or designees), and (c) telephone interviews with state department AT coordinators or designees.

This study will address the following research questions:

1. What types of AT standards \& competencies, if any, currently exist in the states' K-12 education systems in the United States?

2. What types of evidence supports the state AT standards \& competencies in the United States, and how rigorous is the evidence?

3. What degree of implementation is present for AT policies at the state level?

4. What relationship exists between type(s) of AT standard \& teacher competency, level of evidence rigor, and degree of AT implementation and the academic performance of special education students as measured by state reading and math assessments? 
This study will use quantitative methodology and regression analysis to answer the research questions. The predictor or independent variables in this study will be: (a) AT standards \& competencies (defined by Sweeny, 1999), (b) level of evidence rigor used to support AT standards and competencies (defined by Davies, 1999), and (c) extent of AT implementation cited through state sources. The criterion or dependent variable is special education student performance in each state on required state reading and mathematics assessments. Analysis of results should provide important information concerning the existence and/or nature of any significant relationships among the variables.

\section{Significance of the Study}

\section{Role of AT for Students with Special Needs: Literacy as an Example}

The reasons for studying AT standards and competencies, most significantly, are based on the connection between AT and the functioning of students with disabilities in school. AT use in classrooms throughout the U.S. is growing, however barriers and problems with its implementation still exist. AT implementation successes, as well as problems, for students with special needs are exemplified here through a review of studies on literacy-related AT applications. Nationally, increased literacy is a primary national focus of education and involves a number of functional academic areas (reading, writing, spelling, oral communication, etc.). A detailed review of this exemplary topic area is presented below, illustrating the significance of this study to the field of education, although other school subjects could be substituted to reveal similar patterns of AT use and outcomes. 
In the area of literacy, studies focused on writing support software used by students with physical disabilities, either motor or sensory, show that use of AT increases number of words written, reading accuracy, self confidence, and self esteem. Use of the software also reduces frustration and fatigue during writing. These studies also show, however, mixed results regarding effect on rate of writing and on spelling accuracy; some students were aided in some cases, but not is others (Brown \& Cavalier, 1992; Mirenda, Turoldo, \& McAvoy, 2006; Stoner, Esterbrooks, \& Laughton, 2005; Tumlin \& Heller, 2004). In a different study concerning physical access, however, the use of writing software showed no significant effect on contentrelated components of writing (narrative analysis, grammar usage, linkage of cause and effect) except for individuals with both physical and cognitive disabilities (Boone \& Higgins, 2007). Boone and Higgins (2007) state "data from this research reinforce the notion that mere access to the content is inadequate as an AT unless access is mediated with instructional design supports appropriate for the specific disability of the user" (p. 138). In other words, it is not enough just to have physical access to information; it is necessary to know how to apply the information that is accessed, in order for learning to take place.

Other studies involving literacy software, focused on reading and writing for students with cognitive and learning challenges, reach different conclusions. MacArthur and Cavalier (2004) found that students with learning disabilities who used speech recognition software for writing tasks produced higher quality content in computer-generated essays when compared with handwritten essays. Use of dictation, however, by these students produced the highest quality essays (MacArthur \& 
Cavalier, 2004). These findings further confirm the earlier point that application knowledge and physical access are both important. Concerning the process of writing, word prediction software used by students with learning disabilities produced significant differences in spelling and legibility of writing for some students but not for others. Reasons were not clearly identified, but motivation was considered to be a possible factor (MacArthur \& Cavalier, 2004). These studies represent a lack of consistency in literacy-based outcomes as a result of AT implementation.

In studies concerning learning disabilities, Higgins and Raskind (2005) found that students using a verbal reading pen increased in accuracy for decoding words, identifying sight words, and learning independently. Lee and Vail (2005) identified similar results for students who used text reading software. Distraction from the task of reading decreased in these studies. The studies point toward the effectiveness of verbal AT supports for students with learning disabilities, however, the studies were small in size and scope of samples which limits generalizability of findings (Higgins \& Raskind, 2005; Lee \& Vail, 2005). In one case study, an elementary student with learning disabilities used voiced word prediction and word processing to extend the number, repertoire, and use of words, resulting in a reduction of number of questions asked and over-all improvement of quality of written journal passages. As a single case study, however, the author cautions against assuming generalizability of results to other students (Williams, 2002).

In literacy-related research focusing on AT and instruction, a study of students with and without learning disabilities using AT software tools (e.g. speech synthesis, spell-check, etc.) found students who received direct instruction on the use of the AT 
tools showed improved test performance, while those who received no instruction in tool use, showed little to no improvement (Lange, McPhillips, Mulhern, \& Wylie, 2006). Another study on AT, Project ACCESS, found that special education teachers had limited knowledge of simple forms of AT use in schools, and had very little knowledge or experience with more complex forms of AT requiring specific training for student use (Puckett, 2004). These studies (Lange, et al., 2006; Puckett, 2004) exemplify the need for adequate instruction in the use of AT tools, and the importance of achieving teacher competence in AT to be able to provide adequate instruction.

While these studies of AT indicate that while AT has proven to have positive impact on student performance in individual cases, under specific conditions, or with individuals with specific needs, the findings cannot be generalized to conclude that use of AT has a positive impact on overall student academic performance.

\section{Importance of Educational Standards}

For at least the past 10 years, there has been increasing interest throughout the U.S. in educational standards, as exemplified in the professional literature (Alexander, 2002; Awbrey, 1995; Beach \& Lindahl, 2000; Cochran-Smith, 2003; Elmore \& Fuhrman, 1995; Ingvarson, 1998; Kirst, 1997; Sheldon \& Biddle, 1998; Swain \& Pearson, 2003; Wiebe, Taylor, \& Thomas, 2000). Public policies reflect interest in establishing and examining educational standards (Council of Chief State School Officers, 2001; Cradler \& Cradler, 2002; Heise, 1995; U.S. Department of Justice, 2000; U.S. House Committee on Education and the Workplace, 2004; Warger, 1998; Whitehurst, 2003). Such professional and public policy interests are linked by shared concerns regarding U.S. students' lack of adequate academic performance and 
achievement (Baker, Linn, \& Koretz, 2002; Campbell, Hombo, \& Mazzeo, 2000;

Linn, 2000; Perie, Moran, \& Lutkus, 2005).

There is a reciprocal relationship between public educational policies and professional education research. Hargreaves (1999) discusses this relationship, stating that educational researchers must consider the impact of new laws and policies on education, and politicians must consider the findings of educational researchers in order to make informed educational decisions. For this reason, any consideration of educational standards must include the laws and policies that currently exist, as well as the published research of the field.

Educational Technology, Standards, and AT

A review of a decade of research on educational technology and equity during the 1980s (Sutton, 1991) reveals several issues of concern:

(1) Computer implementation practices maintained and exaggerated inequalities in education

(2) Equality issues are complex and involve more than mere access

(3) Widespread inequalities in type of computer use are found in different schools and

(4) Minority and low-income school districts use too much drill and practice and not enough conceptual and problem solving technology to support learning needs

Such issues of inequity in education and possible discrimination relate as well to students with disabilities, a federally-identified minority group. As with other 
technology used in schools, complex equity issues and challenges exist for AT implementation in education.

Since 1997, federal policy has required AT to be considered in the development of every individualized educational program (IEP) for students with disabilities (Schrag \& Ahearn, 1998). The 1997 Individuals with Disabilities Education Act (IDEA) amendments state that the primary placement for students with disabilities must be in the general education classroom, unless such placement proves to be inappropriate for meeting students' needs (Schrag \& Ahearn, 1998). National Educational Technology Standards (NETS) of the International Society for Educational Technology (ISTE) define student, teacher, and administrator standards that are relevant for the general student population. These standards are relevant to AT, as well, since they are intended to address the educational needs of all students, which includes students with disabilities. As participants in the general curriculum, students with disabilities need access to and use of all educational technologies, not just specialized or assistive technologies. Very often, assistive technologies must be connected to general educational technologies in order to function. Therefore, it is inappropriate to consider AT standards and policies without considering relevant educational technology information, as well.

Establishing standards for students and teachers is one way of combating educational inequality. The establishment of educational standards drives the development of necessary teacher competencies, which, in turn, directly relate to the delivery of equitable instruction and effective student supports (Beichner, 1993; Franklin, 2000). National educational standards now exist in such content areas as 
English, math, reading, science, and technology (U.S. Department of Education, 2007a).

In the area of technology, the National Educational Technology Standards (NETS) of the International Society for Technology in Education (ISTE) demonstrate the connection between standards, teacher competencies, and instruction. ISTE, an organization of education professionals, first addressed technology standards by establishing nationwide standards for students' use of technology in U.S. schools (Bitter, Thomas, Knezek, Friske, Taylor, \& Wiebe, 1997). Following the original student standards, educational technology standards for teachers and administrators were later developed (Bitter, et. al, 1997). ISTE developed guidelines, curriculum materials and models that demonstrate what teachers need to do and how they need to teach to support the achievement of these standards (Bitter, et. al, 1997); in other words, ISTE has identified the competencies needed for teachers in the area of educational technology.

In the field of education, established standards for teachers define what teachers need to know and be able to do in order to be considered competent educators (Baker, Linn, \& Koretz, 2002; Council for Exceptional Children, 2003; International Society for Technology in Education, 2007). Increasingly, with the continued growth of inclusion of students with disabilities in general education settings and programs, studies in the fields of AT and educational technology need to be conducted in order to identify the technology standards and teacher competencies that will effectively support students with varying needs. Such study will better inform the development 
of comprehensive and equitable educational technology policies, laws, and research to benefit all students, including students with disabilities.

\section{Types of Standards and Competencies}

Gaining a clear understanding of standards can be difficult, since various types and descriptions of standards exist within various professions (Awbrey, 1995; Barron, Kemker, Harmes, \& Kalaydjian, 2003; Beach \& Lindahl, 2000; Council for Exceptional Children, 2003; Elmore \& Fuhrman, 1995; Haas, 1995; Hammel \& Angelo, 1996; Hill, 2003; Ingvarson, 1998; Kirst, 1997). Confusion can arise if a clear definition of the term "standards" is lacking. For educators, Sweeny (1999) offers clarification of this term "standards" by identifying and defining four specific types of educational standards: content, performance, curriculum, and delivery (Table 1). Content and performance standards focus on what students need to know and be able to do. This definition of content and performance standards is consistent with commonly held descriptions of these terms in the field of education (Lahm \& Nickels, 1999; Lemke, 2003; O’Shea, Stoddard, \& O’Shea, 2000; Peck, 1998; Raizen, 1998;

Sheldon \& Biddle, 1998).

Table 1

Four Categories of Educational Standards (Sweeny, 1999, p. 64)

Standard

\begin{tabular}{|l|l|}
\hline Content & $\begin{array}{l}\text { What students should know and how well } \\
\text { they should be able to use the knowledge }\end{array}$ \\
\hline Performance & $\begin{array}{l}\text { How well students must know and do } \\
\text { specific content assessment tasks }\end{array}$ \\
\hline Curriculum & $\begin{array}{l}\text { What teachers must teach (in order for } \\
\text { students to know what they should know) }\end{array}$ \\
\hline Delivery & $\begin{array}{l}\text { What educators must know and do if } \\
\text { students are to perform at a desired level } \\
\text { (on specific content assessment tasks) }\end{array}$ \\
\hline
\end{tabular}


Curriculum and delivery standards, according to Sweeny (1999), focus on what teachers must know and be able to do in order to support student learning and student performance. This definition of curriculum and delivery standards matches the educational concept of teacher competence, namely, what teachers must know and be able to do to effectively teach their students. There appears to be some confusion in the field of education regarding the use of the terms "standards" and "competencies". Unfortunately, these terms are frequently used interchangeably, inconsistently, and without clear definition. For example, Kovar (2001) discusses teacher proficiency in ISTE technology competencies, while McNear (2005) refers to alignment of Braille literacy and AT with ISTE technology standards. Both are referring to the same documented material. Due to this interchangeable use of terms, literature and policies that reference either standards or competencies are relevant to this study. The national use of terms "standards" and "competencies" is of interest to this study, as well.

\section{Educational Standards and Evidence-Based Practice}

In the educational community today, the focus on educational standards strongly connects to the profession's interest and belief in evidence-based practice. The contemporary concept of evidence-based practice (EBP) originated in the field of medicine during the 1990s in Great Britain (Sackett, Rosenberg, Gray, Haynes, \& Richardson, 1996). Evidence-based practice is defined as "the conscientious, explicit, and judicious use of current best evidence in making decisions about the care of individuals" (Sackett, et. al, 1996, p. 71), and is further defined by Sackett as "integrating individual clinical expertise with best available clinical evidence from systematic research" (p. 71). EBP principles and guidelines have been developed in a 
wide range of medically-related professions, including nursing, occupational therapy, physical therapy, speech language pathology, and social work. Leading British and American educators have begun to incorporate the principles of EBP into instructional practice, citing the importance of acquiring rigorous, empirical evidence to inform instructional practice (Davies, 1999; Hargreaves, 1997, 1999; Slavin, 2002). Philip Davies is the individual often identified as establishing and describing the connection between EBP and education. Davies (1999) states:

"Evidence-based education means integrating individual teaching and learning expertise with the best available external evidence from systematic research" (p.117).

Davies (1999) also states his concern about the current state of evidence in education: “....educational activity is often inadequately evaluated by means of carefully designed and executed controlled trials... (or other research methods)....Moreover, the research and evaluation studies that do exist are seldom searched for systematically, retrieved and read, critically appraised for quality, validity and relevance, and organized and graded for power of evidence. This is the task of evidence-based education" (p.109).

With the prior statement, Davies clearly identifies the need for further research in the application of EBP in education.

Robert Slavin (2002), creator of the research-based comprehensive school reform Success for All, emphasizes the need for "rigorous experiments evaluating replicable programs and practices" (p.15) to build confidence in educational research. Slavin also identifies a need for the greater use of correlational, descriptive, and other 
empirical methods of inquiry in education, expanding the scope of acceptable evidence beyond that of strict random clinical trials (RCT).

Concern and reluctance regarding the interpretation and use of EBP in education have begun to emerge in literature of the field. Primary criticisms are: (1) Narrowness of focus. Identifying high value with a single-method (RCT) of experimental research essentially devalues other research methods for acquiring scientific evidence (Berliner, 2002; Erickson \& Gutierrez, 2002).

(2) Research evidence alone does not take into account the feasibility or desirability of practice (Biesta, 2007; Sanderson, 2003).

(3) Research cannot supply reliable answers on 'what works' due to multiple variables of educational practice, i.e. values, judgments, knowledge, skills, and student factors (Berliner, 2002; Biesta, 2007; Hammersley, 2005).

(4) EBP devalues professional experience, judgment and culture, and restricts input into educational decision-making (Biesta, 2007; Erickson \& Gutierrez, 2002; Hammersley, 2005).

Identification and recognition of these stated concerns is important, so that a balanced view of EBP in the profession of education is maintained. It is fact, however, that the American educational system is implementing the policies of the national No Child Left Behind Act, which requires the use of evidence-based practices. All components of the education system (K-12) in the United States must use empirical research to inform instructional practice (Odom, Brantlinger, Gersten, Horner, Thompson, \& Harris, 2005). Therefore, to address this national priority, it is necessary to consider literature on educational technology and AT through the lens of 
evidence-based practice. As the AT literature has been analyzed in relation to EBP, further analysis was used to specifically address AT standards and competencies by reviewing the nature of evidence in the literature that these standards and competencies were based on. Summation of literature analysis findings is provided at the end of this chapter.

\section{Nature and Rigor of Evidence}

It is important to identify criteria that can help to identify the nature and rigor of evidence. At the 1998 Agency for Health Care Policy and Research Conference in Washington, D.C., a definition of quality of evidence was identified as follows:

"The definition of quality is evidence from studies designed and conducted to protect against systematic and non-systematic bias and errors of inference.

Non-methodologic quality is the extent to which a study has significant clinical or policy relevance or both" (Lohr, 1998).

The consideration of quality in all aspects of practice, through a wide range of evidence sources, is critical in education, as it is critical in medicine, to ensure the integrity of these fields.

Scientific evidence is empirical evidence; evidence that can be measured, as well as methods that can be replicated. There is strong belief that scientific evidence can be organized and graded according to a hierarchy, identifying the rigor or power of the evidence in relation to fidelity of measurement and replication (Bingman, Joyner, \& Smith, 2003; Davies, 1999; Odom, Brantlinger, Gersten, Horner, Thompson, \& Harris, 2005; Sackett, Richardson, Rosenberg, \& Haynes, 1997; Schlosser \& Raghavendra, 2004). Variation exists amongst different professional 
fields regarding the nature of and levels of evidence to use when identifying the rigor of scientific evidence. Five specific systems for the grading of evidence are identified here from literature in the fields of medicine and education (Table 2). 
Table 2

Hierarchies/Continuums/Types of Evidence for EBP

Author

Sackett, Richardson, Rosenberg, \&

Haynes, 1997
Hierarchy

Hierarchy of Evidence:

Level I: Meta Analyses/Systematic Reviews

Level II: Randomized Controlled Trial/

Experimental/Quasi-Experimental

Level III: Descriptive/Case Studies/Series

Level IV: Expert Opinion

Level V: Animal Research/Bench

National Center for the Study of Adult

Learning and Literacy. Bingman, Joyner, \& Smith, 2003

American Speech and Hearing

Association. Schlosser \& Raghavendra, 2004

Davies, 1999

Council for Exceptional Children. Odom, Brantlinger, Gersten, Horner, Thompson \& Harris, 2005
Hierarchy of research for EBP:

I. Experimental: Identical groups, randomly assigned to treatment, and control groups

II. Quasi-Experimental: Treatment and control groups not randomly assigned, but appearing identical

III. Correlational with statistical controls: Treatment and comparison groups not identical but statistics control for important differences

IV. Correlational without statistical controls: Treatment and comparison groups different, but differences assumed not important. For use with large sample.

V. Case studies: Only treatment group, and assumes differences among participants not important. For use with small sample.

Evidence hierarchy:

Level 1) Randomized experimental design or well-designed randomized control studies

Level 2) Controlled studies without randomization (quasiexperimental designs)

Level 3) Well-designed non-experimental studies

(correlational and case studies)

Level 4) Expert opinions (committee reports, consensus conferences, clinical experience of respected authorities)

Continuum of evidence:

1) Randomized controlled trials

2) Experimental \& quasi-experimental studies

3) Survey \& correlational research (simple \& multiple correlation, regression analysis, analysis of variance) 4) Expert opinion (defining of processes, meanings, categories \& practices by field professionals)

5) Ethnographies/case studies/observations (analysis of consequences of activities by interaction/conversation/discourse)

6) Ethics studies (universal vs. selective action, informed choices, social inequities, social justice, resource allocation, and values)

Four types of research in special education:

a) experimental group

b) correlational

c) single subject

d) qualitative designs 
The first grading system originates from Sackett and colleagues, and was developed for the medical field, where the concept of EBP was first defined. In Sackett's system, the hierarchy of evidence ranges from Level V, identified as least rigorous, to Level I, the most rigorous (Sackett, Richardson, Rosenberg, \& Haynes, 1997). In a slightly different evidence hierarchy, identified by the National Center for the Study of Adult Learning and Literacy (NCSALL), evidence ranges from experimental research indicating high rigor, to case studies indicating low rigor (Bingman, Joyner, \& Smith, 2003). The American Speech and Hearing Association (ASHA) is the learned community for speech and hearing professionals and presents a third hierarchy of evidence. Concerned with issues of medicine, education, and scientifically-based evidence, ASHA identifies four levels in determining the rigor of evidence (Schlosser \& Raghavendra, 2004). A continuum of evidence by degree of rigor was identified by Davies (1999) for application in the field of education, and is the fourth system identified in this review. Finally, a fifth system is presented that is non-hierarchical in nature, identified by the Council for Exceptional Children. Table 2 summarizes the components of these five evidence grading systems, as earlier stated. The hierarchy of evidence established by Sackett, et al. (1997), is widely accepted and followed in the field of medicine. A consistently accepted hierarchy of evidence, however, has not yet been established in education. Some educators believe that evidence in education does not follow a prescribed hierarchy of power, value, or rigor. They hold that validity and relevance of evidence in education is best determined internally by local measures and informed by values and moral judgment, rather than determined externally by strict factual judgment or technical knowledge 
assessed through evidence hierarchies, or by the widely referenced and sought after "gold standard" of RCT for evidence (Biesta, 2007; Hammersley, 1997, 2005). Hargreaves (1999) cautions that educational decisions cannot be based upon research evidence alone and that they must take into account a range of contextual factors. His views echo Sackett's original work in EBP. Sackett describes the importance of clinical experience to inform research-based decisions in medicine (Sackett, Rosenberg, Gray, Haynes, \& Richardson, 1996). Hargreaves (1999) recommends that rather than the term evidence-based practice, a more accurate term to use in education is "evidence-informed" practice, to emphasize the interdependency of evidence-based research and practice.

The Division of Research task force of the Council for Exceptional Children identified a non-hierarchical group of research methodologies that address the different types of research questions in special education. These methodologies include experimental group, correlational, single subject, and qualitative methodologies (see Table 2). Decisions regarding relevance and appropriateness of research methods, according to the task force, depend upon the variability of the participants and the complexity of the context, and not upon a previously-established research hierarchy (Odom, Brantlinger, Gersten, Horner, Thompson \& Harris, 2005). Clearly, the field of education has not reached consensus concerning use of a particular EBP hierarchy or grading system.

Evidence-based practices that follow a hierarchy to identify the rigor of evidence, however, are currently of great interest throughout the American education system. The mandates of the current NCLB federal education legislation require 
comprehensive application of scientifically-based research results to improve educational performance. This mandate drives a national interest to establish evidence-based educational practices. Philip Davies, one of the earliest educators to articulate the nature of EBP in education, identifies a range of types of evidence, and well as a continuum of their "power" or rigor (Davies, 1999). As a continuum developed for the field of education, it is particularly relevant to use for the review of evidence on AT standards in education (see Table 2).

By considering the research on AT standards, teacher competencies, and rigor of evidence that informs teacher competencies and teacher preparation, this study will provide information to help address gaps in educational and AT research.

Identification of further gaps, through this research, should point toward important and appropriate directions for future research in AT, and adds to the justification of this study.

\section{Issues of State AT Implementation}

While a need for AT policies and implementation of those policies at the state level has been identified (Bell, 2001), the evidence supporting state AT policies is illusive. The federal government seeks a "gold standard" of evidence for both instructional and curriculum decisions, two major components of any educational policy implementation strategy (Odom, Brantlinger, Gersten, Horner, Thompson, \& Harris, 2005). This gold standard is identified as random clinical trials (RCT) or experimental evidence. Strict adherence to this high standard, however, has come into question by education experts who emphasize the role and value of various forms of evidence to educational decision-making (Berliner, 2002; Biesta, 2005; Erickson \& 
Gutierrez, 2002; Davies, 1999). Following these views, acceptable evidence of AT implementation exist along a range, and often are descriptive in nature, rather than strictly based on experimental evidence (Bausch \& Hasselbring, 2004: Falk, 2002; Roblyer, 2000). One tangible descriptive indicator of AT implementation by states includes the documented standards and/or competencies in state AT or ET policies. Other tangible indicators of AT implementation include state-provided instructions relating to AT implementation, such as stated guidelines for AT and specific materials to support the implementation of AT guidelines. Integration requirements and procedures for AT in the individualized education program (IEP) of students with disabilities K-12, and integration of AT curriculum and delivery expectations into the professional development system of the state departments of education are other indicators of AT implementation. Literature supports these indicators as sources of information on AT implementation in each state (Bausch \& Hasselbring, 2004: Falk, 2002; Roblyer, 2000). Comprehensive studies of such descriptive state indicators could not be identified in current literature. Evidence of these tangible AT implementation indicators is available through public sources, and provides important data on the nature and degree of AT implementation at the state level. These indicators were used in the development of the study survey (Appendix A). Technology Standards, EBP, and AT Implementation

Since little has been written about state K-12 AT standards and their implementation, as documented earlier in this review, consideration of the topic of standards within the closely related field of educational technology (ET) is important. The National Educational Technology Standards (NETS), developed through the 
International Society for Technology in Education (ISTE), have existed since 1998 for students and since 2000 for teachers. In 2004, ISTE reported on states' efforts to implement NETS. Results indicate that $74 \%$ of states reported adopting, adapting, aligning with, or referencing the NETS for students, and the same implementation percentage (though some variation in the specific states in each group) was reported for the NETS for teachers (International Society for Technology in Education, 2007). The NETS have been adopted by National Council for Accreditation in Teacher Education (NCATE) and stand as the required standards for technology implementation in NCATE-accredited U.S. teacher education programs. In a recently published annual report by Education Week, Technology Counts 2006, data on the use and capacity to use technology in K-12 education showed that all but three states (Minnesota, Mississippi, and South Dakota) have state standards for students that include technology. While these standards exist, only four states (Arizona, New York, North Carolina, and Utah) report having state tests for students on technology, indicating a large discrepancy between student standard adoption and standard implementation. Reporting on states' capacity to use technology, the Education Week (2006) report found that 40 states have state technology standards for teachers, 21 require technology coursework for initial licensing, but only 9 require technology training or testing for re-certification or professional development. These figures indicate a discrepancy similar to that found with student technology standards between states' teacher standard adoption and standard implementation. As this report indicates, the educational technology movement has been successful in establishing technology standards for students and teachers, however, implementation and training 
changes to support acquisition of the competencies to achieve these standards lag behind.

A connection between ET standards, AT standards and EBP is not immediately evident in the literature. Sources that identify any specific evidence foundations for educational and AT standards and their implementation are not easily found in published research. To approach the task of identifying and classifying literature relevant to standards and EBP, an organizational strategy was developed and applied based on the works of Sweeny (1999) and Davies (1999) previously described. The purpose of the next section of literature review is specifically to identify and analyze the range of literature available on ET and AT standards in combination with EBP.

\section{Literature Review and Analysis}

\section{Literature Analysis by Standards and EBP}

The literature search yielded 110 research studies, articles, and reports that met criteria for selection when considering types of standards (Sweeny, 1999) and levels of evidence (Davies, 1999) together. ET and AT references, organized by type of standard and level of evidence, are presented in Tables 3 and 4. Due to the wide range of content covered in some items, certain items may appear in two or more categories in the tables. Percentages were calculated for each section within the tables, revealing the extent of literature-based evidence found on technology competencies in each category of standard and area of evidence. Patterns of present and non-present evidence in the literature emphasize a need for further study of AT and EBP, due to the significant lack of certain types of rigorous evidence in many areas of standards. 
From the 110 literature items identified through this process, the literature classification results are presented below.

\section{(1) Range of standards and EBP literature}

In ET (Table 3), most of the literature related to curriculum standards (43\%) and delivery standards (39.5\%). Very little literature was identified in the other areas of content standards (3\%) and performance standards (6\%). The AT literature (Table 4) followed the same pattern. Literature on AT standards and teacher competence focused mainly on curriculum standards (47\%) or delivery standards (47\%). Minimal literature was found relating to performance standards (4.5\%) or content standards $(1.5 \%)$. The large discrepancy between the extent of evidence on curriculum and delivery standards and extent of evidence on content and performance standards is likely due to focus of the literature search causing a skew, rather than to a true lack of this extent of evidence in content and performance literature in the field. This study focused upon teacher-related standards in technology and therefore the literature review concentrated on ET and AT teacher-related literature rather than studentrelated literature. It is very likely that a significant amount of literature could be identified regarding content and performance standards if a student-related literature search were conducted, similar in scope and method to the process followed in this review. Such a search could be helpful in future studies, however was not necessary for this study. 
Table 3

Educational Technology: Evidence Classification by Type of Standard and Level of Rigor in EBP of Identified Literature

Type of Standard (Sweeny, 1999)

\begin{tabular}{|c|c|c|c|c|}
\hline $\begin{array}{l}\text { EBP evidence type by } \\
\text { level of rigor }- \text { high to } \\
\text { low } \\
\text { (Davies, 1999) }\end{array}$ & $\begin{array}{l}\text { Content } \\
\text { standards }\end{array}$ & $\begin{array}{l}\text { Performance } \\
\text { standards }\end{array}$ & $\begin{array}{l}\text { Curriculum } \\
\text { standards }\end{array}$ & $\begin{array}{l}\text { Delivery } \\
\text { standards }\end{array}$ \\
\hline \multicolumn{5}{|l|}{$\begin{array}{l}\text { Randomized controlled } \\
\text { trials }\end{array}$} \\
\hline $\begin{array}{l}\text { Experimental \& quasi- } \\
\text { experimental }\end{array}$ & & & & Baylor (2002). \\
\hline Survey \& correlational & $\begin{array}{l}\text { Rosenfeld \& } \\
\text { Martinez-Pons } \\
\text { (2004). }\end{array}$ & & $\begin{array}{l}\text { Angeli (2005); } \\
\text { Archambault; } \\
\text { Kurlikowich, } \\
\text { Brown, \& } \\
\text { Rezendes (2002); } \\
\text { Bielefeldt } \\
\text { (2001); Burton } \\
\text { (2004); Crane } \\
\text { (2005); Fisher } \\
\text { (1998); Flowers } \\
\text { \& Algozzine } \\
\text { (2000); } \\
\text { Lunenburg \& } \\
\text { Irby (1999); } \\
\text { Rosenfeld \& } \\
\text { Martinez-Pons } \\
\text { (2004); Topper } \\
\text { (2004). }\end{array}$ & $\begin{array}{l}\text { Angeli (2005); } \\
\text { Archambault, } \\
\text { Kurlikowich, } \\
\text { Brown, \& } \\
\text { Rezendes (2002); } \\
\text { Baylor \& Ritchie } \\
\text { (2002); Burton } \\
\text { (2004); Collier, } \\
\text { Weinburgh, \& } \\
\text { Rivera (2004); } \\
\text { Crane (2005); } \\
\text { Ertmer, Conklin, } \\
\text { \& Lewandowski } \\
\text { (2001); Franklin } \\
\text { (2000); Hayes } \\
\text { (2004); } \\
\text { Kankaanranta } \\
\text { (2001); Kemp } \\
\text { (2000); King } \\
\text { (2002); Murphy } \\
\text { (2000). }\end{array}$ \\
\hline Expert opinion & $\begin{array}{l}\text { Lowther, } \\
\text { Bassoppo- } \\
\text { Moyo \& } \\
\text { Morrison } \\
\text { (1998). }\end{array}$ & $\begin{array}{l}\text { Cardillo (2005); } \\
\text { Mann, } \\
\text { Shakeshaft, } \\
\text { Becker, \& } \\
\text { Kottkamp, } \\
\text { (1998). }\end{array}$ & $\begin{array}{l}\text { Bennett (2000); } \\
\text { Bitter, Thomas, } \\
\text { Knezek, Friske, } \\
\text { Taylor, Wiebe, et } \\
\text { al. (1997); Fisher } \\
\text { (1998); Gooler, } \\
\text { Kautzer, \& Knuth } \\
\text { (2000); Heller, } \\
\text { Steiner, } \\
\text { Hockemeyer, \& } \\
\text { Albert (2006); } \\
\text { Kelley, Wetzel, } \\
\text { Padgett, Wiliams, } \\
\text { \& Odom (2004); } \\
\text { Krueger, Hansen, } \\
\text { \& Smaldino } \\
\text { (2000); Peck } \\
\text { (1998); Peck, } \\
\text { Augustine, \& } \\
\text { Popp (2003); } \\
\text { Pettenati, Giuli, } \\
\text { \& Khaled (2001); } \\
\text { Phelps, Hase, \& }\end{array}$ & $\begin{array}{l}\text { Albee (2003); } \\
\text { Bennett (2005); } \\
\text { Bitter, Thomas, } \\
\text { Knezek, Friske, } \\
\text { Taylor, Wiebe, et } \\
\text { al. (1997); } \\
\text { Cardillo (2005); } \\
\text { Caverly \& } \\
\text { MacDonald } \\
\text { (2005); Chiero, } \\
\text { Sherry, Bohlin, \& } \\
\text { Harris (2003); } \\
\text { Gooler, Kautzer, } \\
\text { \& Knuth (2000); } \\
\text { Lowther, } \\
\text { Bassoppo-Moyo } \\
\text { \& Morrison } \\
\text { (1998); } \\
\text { Persichitte, } \\
\text { Caffarella, \& } \\
\text { Ferguson-Pabst } \\
\text { (2003); Pettenati, } \\
\text { Giuli, \& Khaled }\end{array}$ \\
\hline
\end{tabular}




\begin{tabular}{|c|c|c|c|}
\hline & & $\begin{array}{l}\text { Ellis (2005); } \\
\text { Smith (2000). } \\
\text { Thomas \& } \\
\text { Knezek (2002); } \\
\text { Thompson, } \\
\text { Lazarus, Clapper, } \\
\text { \& Thurlow } \\
\text { (2004); Topper } \\
\text { (2004). }\end{array}$ & $\begin{array}{l}\text { (2001); Smith } \\
\text { (2000); Thomas } \\
\text { \& Knezek } \\
\text { (2002); Spitzer } \\
\text { (2003); } \\
\text { Waddoups, } \\
\text { Wentworth, \& } \\
\text { Earle 2004); } \\
\text { Waugh, Levin, \& } \\
\text { Buell (1999); } \\
\text { Wilson (2003). }\end{array}$ \\
\hline $\begin{array}{l}\text { Ethnographies/case } \\
\text { studies/observations }\end{array}$ & $\begin{array}{l}\text { Mann, } \\
\text { Shakeshaft, } \\
\text { Becker, \& } \\
\text { Kottkamp, } \\
\text { (1998). }\end{array}$ & $\begin{array}{l}\text { Beasley \& Wang } \\
\text { (2001); Hawsawi } \\
\text { (2002); Kelley, } \\
\text { Wetzel, Padgett, } \\
\text { Wiliams, \& } \\
\text { Odom (2004); } \\
\text { Sandholtz \& } \\
\text { Reilly (2004); } \\
\text { Stuhlmann \& } \\
\text { Taylor (1999). }\end{array}$ & $\begin{array}{l}\text { Beasley \& Wang } \\
\text { (2001); Hawsawi } \\
\text { (2002); King, K. } \\
\text { P. (2002); } \\
\text { Niederhouser \& } \\
\text { Lindstrom } \\
\text { (2006); Wilson } \\
\text { (2003). }\end{array}$ \\
\hline Ethics studies & & $\begin{array}{l}\text { Osguthorpe, } \\
\text { Osguthorpe, } \\
\text { Jacob \& Davies } \\
\text { (2003). }\end{array}$ & $\begin{array}{l}\text { Waugh, Levin, \& } \\
\text { Buell (1999). }\end{array}$ \\
\hline
\end{tabular}


Table 4

Assistive Technology: Evidence Classification by Type of Standard and Level of Rigor in EBP of Identified Literature

\begin{tabular}{|c|c|c|c|c|}
\hline \multicolumn{5}{|c|}{ Type of Standard (Sweeny, 1999) } \\
\hline $\begin{array}{l}\text { EBP evidence type by } \\
\text { level of rigor }- \text { high to } \\
\text { low } \\
\text { (Davies, 1999) }\end{array}$ & $\begin{array}{l}\text { Content } \\
\text { standards }\end{array}$ & $\begin{array}{l}\text { Performance } \\
\text { standards }\end{array}$ & $\begin{array}{l}\text { Curriculum } \\
\text { standards }\end{array}$ & $\begin{array}{l}\text { Delivery } \\
\text { standards }\end{array}$ \\
\hline \multicolumn{5}{|l|}{$\begin{array}{l}\text { Randomized controlled } \\
\text { trials }\end{array}$} \\
\hline \multicolumn{5}{|l|}{$\begin{array}{l}\text { Experimental \& quasi- } \\
\text { experimental }\end{array}$} \\
\hline Survey \& correlational & & $\begin{array}{l}\text { Kim-Rupnow, } \\
\text { \& Burgstahler } \\
\text { (2004); Puckett } \\
\text { (2004). }\end{array}$ & $\begin{array}{l}\text { Campbell (2000); } \\
\text { Dissinger (2003); } \\
\text { Hirumi \& Grau } \\
\text { (1996); Kanny \& } \\
\text { Anson (1998); } \\
\text { Lenker (1998); } \\
\text { Maushak, Kelley, } \\
\text { \& Blodgett (2001); } \\
\text { Michaels \& } \\
\text { McDermott } \\
\text { (2003); Riley, } \\
\text { Beard, \& Strain } \\
\text { (2004); Weber } \\
\text { (1998). }\end{array}$ & $\begin{array}{l}\text { Bell (2001); Bell } \\
\text { \& Blackhurst } \\
\text { (1996); Derer, } \\
\text { Polsgrove, \& } \\
\text { Rieth (1996); } \\
\text { Hirumi \& Grau } \\
\text { (1996); Lahm \& } \\
\text { Sizemore } \\
\text { (2002); Michaels } \\
\text { \& McDermott } \\
\text { (2003). }\end{array}$ \\
\hline Expert opinion & $\begin{array}{l}\text { McNear } \\
\text { (2005). }\end{array}$ & & $\begin{array}{l}\text { Bausch \& } \\
\text { Hasselbring } \\
\text { (2004); Behrmann } \\
\text { \& Jerome (2002); } \\
\text { California Dept. of } \\
\text { Education (2006); } \\
\text { Council for } \\
\text { Exceptional } \\
\text { Children. (2003); } \\
\text { Day \& Huefner } \\
\text { (2003); Edyburn } \\
\text { (2005); Feyerer, } \\
\text { Miesenberger, \& } \\
\text { Wohlart (2002); } \\
\text { Fitzgerald, Hardin, } \\
\text { \& Hollingsead } \\
\text { (1997); Hammel \& } \\
\text { Angelo (1996); } \\
\text { Lahm (2000); } \\
\text { Lahm (2003); } \\
\text { Lahm \& Nickels } \\
\text { (1999); Nickels } \\
\text { (1999); Parette } \\
\text { (1997); Pisha \& } \\
\text { Stahl (2005); } \\
\text { Rowley, Mitchell, } \\
\text { \& Weber (1997); } \\
\text { Smith (2000); } \\
\text { Thompson, } \\
\text { Lazarus, Clapper, }\end{array}$ & $\begin{array}{l}\text { Bowser \& Reed } \\
\text { (1995); } \\
\text { Campbell, } \\
\text { Milbourne, \& } \\
\text { Dugan (2006); } \\
\text { Chen, Wu, \& } \\
\text { Chu (2004); } \\
\text { Council for } \\
\text { Exceptional } \\
\text { Children. } \\
\text { (2003); Day \& } \\
\text { Huefner (2003); } \\
\text { Edyburn (2005); } \\
\text { Edyburn \& } \\
\text { Gardner (1999); } \\
\text { Hammel \& } \\
\text { Angelo (1996); } \\
\text { Lahm (2000); } \\
\text { Lahm (2003); } \\
\text { Lahm \& Nickels } \\
\text { (1999); Nickels } \\
\text { (1999); Parette } \\
\text { (1997); Pisha \& } \\
\text { Stahl (2005); } \\
\text { QIAT } \\
\text { Consortium } \\
\text { Leadership } \\
\text { Team (2000); } \\
\text { Smith (2000); } \\
\text { Smith \& Jones }\end{array}$ \\
\hline
\end{tabular}




\begin{tabular}{|c|c|c|c|}
\hline & & $\begin{array}{l}\text { \& Thurlow (2004); } \\
\text { Zabala (1995). }\end{array}$ & $\begin{array}{l}\text { (1999); Snell, } \\
\text { Caves, McLean, } \\
\text { Mollica, } \\
\text { Mirenda, Paul- } \\
\text { Brown, et al. } \\
\text { (2003); Soto, } \\
\text { Muller, Hunt, \& } \\
\text { Goetz (2001); } \\
\text { Treviranus \& } \\
\text { Coombs (2000); } \\
\text { Zabala (1995); } \\
\text { Zabala, Blunt, } \\
\text { Carl, Davis, } \\
\text { Deterding, Foss, } \\
\text { et al. (2000); } \\
\text { Zabala \& Carl } \\
\text { (2004). }\end{array}$ \\
\hline $\begin{array}{l}\text { Ethnographies/case } \\
\text { studies/observations }\end{array}$ & Puckett (2004). & $\begin{array}{l}\text { Hawsawi (2002); } \\
\text { Michaels \& } \\
\text { McDermott } \\
\text { (2003). }\end{array}$ & $\begin{array}{l}\text { Hawsawi (2002); } \\
\text { Michaels \& } \\
\text { McDermott } \\
\text { (2003); Sax, } \\
\text { Fisher, \& } \\
\text { Pumpian (1996). }\end{array}$ \\
\hline Ethics studies & & & \\
\hline
\end{tabular}


Results from the literature review are more striking regarding EBP evidence type and level of evidence rigor. Concerning ET, in the category of randomized clinical trials (RCT), no literature at all (0\%) was identified regarding teacher technology competencies based upon evidence gathered through RCT, for any of the four types of educational standards. In the experimental/quasi-experimental category, only one study (1.5\%) was identified. The study related specifically to the category of delivery standards for teachers. The majority of ET literature was identified as either survey/correlational (33.5\%) or expert opinion (47.5\%). Some ET literature was found based upon ethnographies/case studies/observations (14.5\%), and the remaining literature fell into the category of ethics studies (4.5\%).

AT literature revealed similarities in pattern to that of ET literature. Literature concerning AT standards and teacher competencies contained no identified items that were based upon RCT $(0 \%)$ or experimental/quasi-experimental $(0 \%)$ evidence. A moderate amount of AT literature evidence was survey/correlational (26\%). However, the majority of evidence reviewed on AT standards and teacher competencies was based upon expert opinion (64.5\%). Some AT literature was found in the category of ethnographies/case studies/observations (9.5\%), and no AT literature was found for the category of ethics studies $(0 \%)$

The nature and rigor of evidence present in technology standards and teacher competence literature is important. The historical development of EBP within medicine reveals recognition of the value of various types and levels of information from both scientific and clinical perspectives in developing EBP (Bingman, Joyner, \& Smith, 2003; Davies, 1999; Sackett, Richardson, Rosenberg, \& Haynes, 1997; 
Schlosser \& Raghavendra, 2004). Conceptualization of EBP, however, seems to have become clouded as it has been applied to the field of education. As discussed earlier, it is clear that some major factions within education believe that evidence must be experimentally proven in order to be deemed scientifically rigorous and acceptable (Odom, Brantlinger, Gersten, Horner, Thompson, \& Harris, 2005). These factions identify RCT as the "gold standard" for all evidence-based research and practices. The value of clinical information is not emphasized by these factions, and often is not mentioned. Other factions in education, however, identify different types of evidence as being acceptable for the development of evidence-based practices (Biesta, 2007; Hammersley, 1997, 2005). This second group assigns greater value to clinical and expert input for decision-making regarding EBP. Both factions seem, however, to be functioning under a basic misconception of EBP. The model of EBP advocates using the highest, most rigorous evidence available to inform practice. In some cases, expert opinion, although not highly rigorous, is the most rigorous evidence available. But, if expert opinion and correlational evidence is available, the more rigorous correlational evidence should take precedence. In addition, the role of practical or clinical evidence must always be considered. It is of paramount importance that educators and policy makers understand this basic EBP principle, and the interdependency of scientific and clinical evidence.

Notable are the findings that literature of ET and AT yield clearly little-to-no experimental evidence in the area of standards and teacher competencies for ET and AT (Tables $3 \&$ 4). No RCT or experimental evidence was found concerning AT standards or teacher competencies. The most rigorous evidence available in the 
literature was survey/correlational evidence. Approximately one fourth of the AT evidence was survey or correlational evidence. Much survey evidence was descriptive. Fewer of these studies used correlational statistical procedures to analyze responses and patterns. The majority of AT literature included in this review is based upon expert opinion evidence (64.5\%), much of which was generated using the

Delphi method, a process of organized collection of multiple rounds of expert opinion. The published standards of the Council for Exceptional Children (CEC), for special education technology specialists, were developed through the Delphi method and through the CEC standard validation process, which is also based upon expert opinion (Council for Exceptional Children, 2003). This literature review reveals that expert opinion is the most commonly used evidentiary process in the development of decisions, policies, and practices regarding AT standards and teacher competencies (Table 4).

If technology standards and teacher competencies for ET and AT are required by national guidelines to be based on experimental evidence, and there is no research evidence available in the field, a void of acceptable evidence would then exist, leading to a potential crisis in educational policy. More information, research, and varying research methods are needed in this area.

\section{(2) Range of topics}

In addition to identifying the range of standards and EBP in the literature, it is also important to identify the topic focus of the 110 items, in order to understand the body of work available in the field. Use of an efficient means of organization is necessary in order to understand the scope of available literature. Past AT literature 
reviews by David Edyburn (2002a, 2003, \& 2004) have organized articles by topic, which is an effective way to identify major content themes in the literature and to efficiently manage a large number of literature items. This topical organization process, with $1-3$ topic descriptors identified for each piece of literature, was applied to the 110 items, allowing for some items to appear in multiple topic areas (Table 5). Many of the topic descriptors identified by Edyburn have been used, however new descriptors were added as necessary to address the full scope of this literature review. The seventeen topic descriptors used are presented below, together with total number of references in each topic area identified in parentheses.

Access to general curriculum (8)

AT knowledge and skills (32)

AT policies/standards (15)

Competencies (23)

Educational reform (7)

Educational theory (2)

Ethics in educational technology (2)

Evidence/research-based practice (5)

Individuals with Disabilities Education Act (5)

Preservice and inservice teacher/service provider education (36)

Research-based decision-making (3)

Scientifically based interventions (2)

Special education standards (4)

Standards (4)

Teachers' knowledge and skills (27)

Technology knowledge and skills (37)

Technology standards (13) 
Table 5

Literature by topic ( $1-3$ descriptors per item)

Topic

Literature reference

\begin{tabular}{|c|c|}
\hline Access to general curriculum & $\begin{array}{l}\text { Abell, Bauder, \& Simmons (2005); Bennett (2005); Chen, Wu, \& Chu } \\
\text { (2004); Kim-Rupnow \& Burgstahler (2004); Lahm (2003); Maushak, } \\
\text { Kelley \& Blodgett (2001); Pisha \& Stahl (2005); Puckett (2004); Sax, } \\
\text { Fisher, \& Pumpian (1996); Smith \& Jones (1999); Soto, Muller, Hunt, } \\
\text { \& Goetz (2001); Treviranus \& Coombs (2000). }\end{array}$ \\
\hline $\begin{array}{l}\text { Assistive technology } \\
\text { knowledge \& skills }\end{array}$ & $\begin{array}{l}\text { Bausch \& Hasselbring (2004); Behrmann \& Jerome (2002); Bell } \\
\text { (2001); Bell \& Blackhurst (1996); Bowser \& Reed (1995); Campbell } \\
\text { (2000); Campbell, Milbourne, \& Dugan (2006); Chen, Wu, \& Chu } \\
\text { (2004); Derer, Polsgrove, \& Rieth (1996); Dissinger (2003); Edyburn } \\
\text { \& Gardner (1999); Feyerer, Miesenberger, \& Wohlart (2002); Hammel } \\
\text { \& Angelo (1996); Hawsawi (2002); Kanny \& Anson (1998); Kim- } \\
\text { Rupnow \& Burgstahler (2004); Lahm (2000); Lahm (2003); Lahm \& } \\
\text { Nickels (1999); Lenker (1998); Maushak, Kelley \& Blodgett (2001); } \\
\text { Michaels \& McDermott (2003); Nickels (1999); Parette (1997); } \\
\text { Puckett (2004); Riley, Beard, \& Strain (2004); Rowley, Mitchell, \& } \\
\text { Weber (1997); Sax, Fisher, \& Pumpian (1996); Smith (2000); Zabala } \\
\text { (1995); Zabala, Blunt, Carl, Davis, Deterding, Foss, et al. (2000); } \\
\text { Zabala \& Carl (2004). }\end{array}$ \\
\hline $\begin{array}{l}\text { Assistive technology } \\
\text { policies/standards }\end{array}$ & $\begin{array}{l}\text { Bell (2001); Bell \& Blackhurst (1996); California Department of } \\
\text { Education (2006); Day \& Huefner (2003); Edyburn (2005); Lahm } \\
\text { (2000); Lahm (2003); McNear (2005); Nickels (1999); QIAT } \\
\text { Consortium Leadership Team (2000); Smith \& Jones (1999); Snell, } \\
\text { Caves, McLean, Mollica, Mirenda, Paul-Brown, et al. (2003); Weber } \\
\text { (1998); Zabala, Blunt, Carl, Davis, Deterding, Foss, et al. (2000); } \\
\text { Zabala \& Carl (2004). }\end{array}$ \\
\hline Competencies & $\begin{array}{l}\text { Angeli (2005); Archambault, Kurlikowich, Brown, \& Rezendes } \\
\text { (2002); Burton (2004); California Department of Education (2006); } \\
\text { Chen, Wu, \& Chu (2004); Edyburn (2005); Fisher (1998); Flowers \& } \\
\text { Algozzine (2000); Franklin, T. J. (2000); Gooler, Kautzer \& Knuth } \\
\text { (2000); Hammel \& Angelo (1996); Hawsawi (2002); Hayes (2004); } \\
\text { Heller, Steiner, Hockemeyer, \& Albert (2006); Kemp (2000); Lahm \& } \\
\text { Nickels (1999); Lowther, Bassoppo-Moyo, \& Morrison (1998); } \\
\text { Nickels (1999); Pettenati, Giuli, \& Khaled (2001); Phelps, Hase, \& } \\
\text { Ellis (2005); Stuhlmann \& Taylor (1999); Thompson, Lazarus, } \\
\text { Clapper, \& Thurlow (2004); Waugh, Levin, \& Buell (1999). }\end{array}$ \\
\hline Educational reform & $\begin{array}{l}\text { Behrmann \& Jerome (2002); Lowther, Bassoppo-Moyo, \& Morrison } \\
\text { (1998); Lunenburg \& Irby (1999); Phelps, Hase, \& Ellis (2005); } \\
\text { Rosenfeld \& Martinez-Pons (2004); Sheldon \& Biddle (1998); } \\
\text { Treviranus \& Coombs (2000). }\end{array}$ \\
\hline Educational theory & $\begin{array}{l}\text { Heller, Steiner, Hockemeyer, \& Albert (2006); Niederhouser \& } \\
\text { Lindstrom (2006). }\end{array}$ \\
\hline $\begin{array}{l}\text { Ethics in educational } \\
\text { technology }\end{array}$ & $\begin{array}{l}\text { Osguthorpe, Osguthorpe, Jacob, \& Davies (2003); Waugh, Levin, \& } \\
\text { Buell (1999). }\end{array}$ \\
\hline $\begin{array}{l}\text { Evidence/research-based } \\
\text { practice }\end{array}$ & $\begin{array}{l}\text { Baylor (2002); Campbell, Milbourne, \& Dugan (2006); Niederhouser } \\
\text { \& Lindstrom (2006); Sax, Fisher, \& Pumpian (1996); Spitzer (2003). }\end{array}$ \\
\hline $\begin{array}{l}\text { Individuals with Disabilities } \\
\text { Education Act }\end{array}$ & $\begin{array}{l}\text { Bell (2001); Bell \& Blackhurst (1996); Campbell (2000); Lahm \& } \\
\text { Sizemore (2002); QIAT Consortium Leadership Team (2000). }\end{array}$ \\
\hline $\begin{array}{l}\text { Preservice \& inservice } \\
\text { teacher/service provider } \\
\text { education }\end{array}$ & $\begin{array}{l}\text { Albee (2003); Angeli (2005); Bausch \& Hasselbring (2004); Baylor } \\
\text { (2002); Beasley \& Wang (2001); Bennett (2000); Bielefeldt (2001); } \\
\text { Caverly \& MacDonald (2005); Collier, Weinburgh, \& Rivera (2004); } \\
\text { Council for Exceptional Children (2003); Dissinger (2003); Edyburn \& }\end{array}$ \\
\hline
\end{tabular}




\begin{tabular}{|c|c|}
\hline & $\begin{array}{l}\text { Gardner (1999); Ertmer, Conklin, \& Lewandowski (2001); Feyerer, } \\
\text { Miesenberger, \& Wohlart (2002); Fitzgerald, Hardin, \& Hollingsead } \\
\text { (1997); Hirumi \& Grau (1996); Kanny \& Anson (1998); Kelley, } \\
\text { Wetzel, Padgett, Williams, \& Odom (2004); Kemp (2000); Krueger, } \\
\text { Hansen, \& Smaldino (2000); Lenker (1998); Maushak, Kelley \& } \\
\text { Blodgett (2001); Michaels \& McDermott (2003); Murphy (2000); } \\
\text { Peck, Augustine, \& Popp (2003); Persichitte, Caffarella, \& Ferguson- } \\
\text { Pabst (2003); Pettenati, Giuli, \& Khaled (2001); Riley, Beard, \& Strain } \\
\text { (2004); Rowley, Mitchell, \& Weber (1997); Sandholtz \& Reilly } \\
\text { (2004); Smith (2000); Stuhlmann \& Taylor (1999); Thompson, } \\
\text { Lazarus, Clapper, \& Thurlow (2004); Topper (2004); Weber (1998); } \\
\text { Wilson (2003). }\end{array}$ \\
\hline $\begin{array}{l}\text { Research-based decision- } \\
\text { making }\end{array}$ & Baylor (2002); Lahm \& Sizemore (2002); Zabala (1995). \\
\hline $\begin{array}{l}\text { Scientifically based } \\
\text { interventions }\end{array}$ & Campbell, Milbourne, \& Dugan (2006); Pisha, B., \& Stahl, S. (2005). \\
\hline Special education standards & $\begin{array}{l}\text { Council for Exceptional Children (2003); Day \& Huefner (2003); } \\
\text { Lahm (2000); QIAT Consortium Leadership Team (2000). }\end{array}$ \\
\hline Standards & $\begin{array}{l}\text { Cardillo (2005); Lunenburg \& Irby (1999); Sheldon \& Biddle (1998); } \\
\text { Thompson, Lazarus, Clapper, \& Thurlow (2004). }\end{array}$ \\
\hline $\begin{array}{l}\text { Teachers' knowledge and } \\
\text { skills }\end{array}$ & $\begin{array}{l}\text { Abell, Bauder, \& Simmons (2005); Bausch \& Hasselbring (2004); } \\
\text { Baylor \& Ritchie (2002); Bielefeldt (2001); Bitter, Thomas, Knezek, } \\
\text { Friske, Taylor, Wiebe, et al. (1997); Bowser \& Reed (1995); Burton } \\
\text { (2004); Campbell (2000); Cardillo (2005); Chiero, Sherry, Bohlin, \& } \\
\text { Harris (2003); Crane (2005); Derer, Polsgrove, \& Rieth (1996); } \\
\text { Dissinger (2003); Dugger (1999); Edyburn (2005); Edyburn \& Gardner } \\
\text { (1999); Ertmer, Conklin, \& Lewandowski (2001); Gooler, Kautzer \& } \\
\text { Knuth (2000); Hawsawi, (2002); Heller, Steiner, Hockemeyer, \& } \\
\text { Albert (2006); Kankaanranta (2001); King (2002); Mann, Shakeshaft, } \\
\text { Becker, \& Kottkamp (1998); Michaels \& McDermott (2003); Peck } \\
\text { (1998); Rosenfeld \& Martinez-Pons (2004); Soto, Muller, Hunt, \& } \\
\text { Goetz (2001); Waddoups, Wentworth, \& Earle (2004). }\end{array}$ \\
\hline $\begin{array}{l}\text { Technology knowledge \& } \\
\text { skills }\end{array}$ & $\begin{array}{l}\text { Albee (2003); Archambault, Kurlikowich, Brown, \& Rezendes (2002); } \\
\text { Baylor \& Ritchie (2002); Bennett (2005); Bielefeldt (2001); Burton } \\
\text { (2004); Caverly \& MacDonald (2005); Chiero, Sherry, Bohlin, \& } \\
\text { Harris (2003); Collier, Weinburgh, \& Rivera (2004); Crane (2005); } \\
\text { Ertmer, Conklin, \& Lewandowski (2001); Feyerer, Miesenberger, \& } \\
\text { Wohlart (2002); Fisher (1998); Fitzgerald, Hardin, \& Hollingsead } \\
\text { (1997); Flowers \& Algozzine (2000); Gooler, Kautzer \& Knuth } \\
\text { (2000); Hammel \& Angelo (1996); Hayes (2004); Kankaanranta } \\
\text { (2001); Kelley, Wetzel, Padgett, Williams, \& Odom (2004); Kemp } \\
\text { (2000); King, (2002); Krueger, Hansen, \& Smaldino (2000); Lowther, } \\
\text { Bassoppo-Moyo, \& Morrison (1998); Lunenburg \& Irby (1999); } \\
\text { Mann, Shakeshaft, Becker \& Kottkamp (1998); Murphy (2000); Peck, } \\
\text { Augustine, \& Popp (2003); Persichitte, Caffarella, \& Ferguson-Pabst } \\
\text { (2003); Pettenati, Giuli, \& Khaled (2001); Rosenfeld \& Martinez-Pons } \\
\text { (2004); Sandholtz \& Reilly (2004); Spitzer (2003); Topper (2004); } \\
\text { Waddoups, Wentworth, \& Earle (2004); Waugh, Levin, \& Buell } \\
\text { (1999); Wilson (2003). }\end{array}$ \\
\hline Technology standards & $\begin{array}{l}\text { Angeli (2005); Beasley \& Wang (2001); Bennett (2000); Bitter, } \\
\text { Thomas, Knezek, Friske, Taylor, Wiebe, et al. (1997); Cardillo (2005); } \\
\text { Dugger (1999); Flowers \& Algozzine (2000); Franklin (2000); Hirumi } \\
\text { \& Grau (1996); McNear (2005); Niederhouser \& Lindstrom (2006); } \\
\text { Peck (1998); Thomas \& Knezek (2002). }\end{array}$ \\
\hline
\end{tabular}


The most frequent topical focus of the articles, research and reports included in the 110 items was the area of knowledge and skills, specifically concerning AT, teachers, and technology. These three knowledge and skills areas have a total of 96 references. The topic of competencies was addressed in a large number of, (specifically 23) articles and reports. Technology competencies are built from identified knowledge and skills needed by teachers to be competent technology and AT users in educational settings. Closely related to the idea of necessary knowledge and skills in technology for teachers is the area of preservice and inservice teacher/service provider education, for which 36 articles and reports were identified. A moderate number of articles, studies and reports were found with the primary focus on standards, special education standards, AT policies and standards, and technology standards. Very little literature was identified in the topical areas of evidence-based practice, research-based decision-making, or scientifically based interventions. While formal comparison of percentages to the total number of articles is not valid, due to the possibility of multiple topic reference used from each item, comparison of the number of references in each clustered topic area shows the following:

(a) Approximately 3 times more references were identified on knowledge and skills topics than on preservice/inservice topics;

(b) Approximately 3 times more references were identified on knowledge and skills topics than on standards topics;

(c) Approximately 4 times more references were identified on knowledge and skills topics than on competencies topics; and 
(d) Approximately 13 times more references were identified on knowledge and skills than on research or evidence-based topics.

From these findings it is apparent that the field of education is more familiar with and more focused on studying teachers' knowledge and skills rather than on studying the issues of EBP, standards or policies, areas that typically offer guidelines for determining and assessing knowledge and skills. More information to guide technology knowledge and skill development in education is needed. Therefore, EBP in education, technology policies, and technology standards, particularly AT standards, require and deserve more extensive study.

Practically all of the available literature on the topic of AT policies and standards views these issues from a broad, national perspective. While the U.S. Department of Education oversees the state educational agencies, it is the individual state departments of education that are responsible for establishing and implementing standards and competencies required for licensing teachers in each state. This means that decisions regarding AT standards and teacher competencies are made and implemented at the state level. Only one study (California Department of Education, 2006) was identified that examined current AT standards at a state level. Research that is focused upon understanding policies, practices, and needs relevant to AT standards at a state level is clearly needed.

\section{Summation of Literature Review Findings}

Literature in the fields of ET and AT was thoroughly reviewed with regard to the issues of standards and EBP. Percentages of various areas of relevant literature found in the fields of ET and AT are presented in Tables $6 \& 7$. Clearly evident is the 
greater amount of evidence identified that was based on expert opinion or

survey/correlational studies than on any of the other types of evidence. This was

found to be true for both the ET and AT fields.

Table 6

Educational Technology: Percentage of Evidence Found by Type of Standard and Level of Rigor in EBP within Identified Literature

Type of Standard (Sweeny, 1999)

\begin{tabular}{|l|l|l|l|l|}
\hline $\begin{array}{l}\text { EBP evidence type by } \\
\text { level of rigor - } \\
\text { high to low } \\
\text { (Davies, 1999) }\end{array}$ & $\begin{array}{l}\text { Content } \\
\text { standards }\end{array}$ & $\begin{array}{l}\text { Performance } \\
\text { standards }\end{array}$ & $\begin{array}{l}\text { Curriculum } \\
\text { standards }\end{array}$ & $\begin{array}{l}\text { Delivery } \\
\text { standards }\end{array}$ \\
\hline $\begin{array}{l}\text { Randomized } \\
\text { controlled trials }\end{array}$ & $0 \%$ & $0 \%$ & $0 \%$ & $0 \%$ \\
\hline $\begin{array}{l}\text { Experimental \& } \\
\text { quasi-experimental }\end{array}$ & $0 \%$ & $0 \%$ & $0 \%$ & $1.5 \%$ \\
\hline $\begin{array}{l}\text { Survey \& } \\
\text { correlational }\end{array}$ & $1.5 \%$ & $0 \%$ & $14 \%$ & $18 \%$ \\
\hline Expert opinion & $1.5 \%$ & $3 \%$ & $6.5 \%$ & $6.5 \%$ \\
\hline $\begin{array}{l}\text { Ethnographies/case } \\
\text { studies/observations }\end{array}$ & $0 \%$ & $1.5 \%$ & $1.5 \%$ & $1.5 \%$ \\
\hline Ethics studies & $0 \%$ & $1.5 \%$ & & $22 \%$ \\
\hline
\end{tabular}

Table 7

Assistive Technology: Percentage of Evidence Found by Type of Standard and Level of Rigor in EBP within Identified Literature

\begin{tabular}{|c|c|c|c|c|}
\hline \multicolumn{5}{|c|}{ Type of Standard (Sweeny, 1999) } \\
\hline $\begin{array}{l}\text { EBP evidence type by } \\
\text { level of rigor - high } \\
\text { to low } \\
\text { (Davies, 1999) }\end{array}$ & $\begin{array}{l}\text { Content } \\
\text { standards }\end{array}$ & $\begin{array}{l}\text { Performance } \\
\text { standards }\end{array}$ & $\begin{array}{l}\text { Curriculum } \\
\text { standards }\end{array}$ & $\begin{array}{l}\text { Delivery } \\
\text { standards }\end{array}$ \\
\hline $\begin{array}{l}\text { Randomized } \\
\text { controlled trials }\end{array}$ & $0 \%$ & $0 \%$ & $0 \%$ & $0 \%$ \\
\hline $\begin{array}{l}\text { Experimental \& } \\
\text { quasi-experimental }\end{array}$ & $0 \%$ & $0 \%$ & $0 \%$ & $0 \%$ \\
\hline $\begin{array}{l}\text { Survey \& } \\
\text { correlational }\end{array}$ & $0 \%$ & $3 \%$ & $14 \%$ & $9 \%$ \\
\hline Expert opinion & $1.5 \%$ & $0 \%$ & $30 \%$ & $33 \%$ \\
\hline $\begin{array}{l}\text { Ethnographies/case } \\
\text { studies/observations }\end{array}$ & $0 \%$ & $1.5 \%$ & $3 \%$ & $5 \%$ \\
\hline Ethics studies & $0 \%$ & $0 \%$ & $0 \%$ & $0 \%$ \\
\hline
\end{tabular}

The results of the literature analysis have been summarized according to specific

points, and are presented below:

(a) While considerable attention has been given to the inclusion of AT in

federal legislation (Aleman, 1991; Association for the Advancement of Rehabilitation 
Research, 2007; U.S. Department of Justice, 2007; U.S. Department of Labor, 2007b), guidelines needed for successful implementation of AT in education are lacking (Bell, 2001; Bell \& Blackhurst, 1996; Lenker \& Paquet, 2004).

(b) Many students benefit positively from use of AT in school programs (Calculator, 1999; Hutinger, Johanson, \& Stoneburner, 1996; Todis, 1996), however the outcomes from AT use by students in special education are not always positive (Johnston \& Evans, 2005; Kittel, DiMarco, \& Stewart, 2002; Light, 1999; Phillips \& Zhao, 1993; Riemer-Reiss \& Wacker, 2000). Successful student use of AT depends upon the presence of many factors involved with AT implementation (Hutinger, Johanson, \& Stoneburner, 1996; Riemer-Reiss \& Wacker, 2000; Todis, 1996). Access alone is not sufficient to ensure success in AT use (Boone \& Higgins, 2007; Brown \& Cavalier, 1992; Lange, McPhillips, Mulhern, \& Wylie, 2006; Mirenda, Turoldo, \& McAvoy, 2006; Stoner, Esterbrooks, \& Laughton, 2005; Tumlin \& Heller, 2004).

(c) Barriers to effective AT use exist at individual, classroom, and system levels (Alper \& Raharinirina, 2006; Behrmann \& Jerome, 2002; Bowser \& Reed, 1995; Carey \& Sale, 1994; Hasselbring \& Glaser, 2000; MacArthur, Graham, Haynes, \& De La Paz, 1996; MacArthur, Haynes, Malouf, Harris, \& Owens, 1990; McInerney, Riley, \& Osher, 1999; Raskind \& Higgins, 1995). Few studies have examined AT implementation at state and federal system levels (Bell, 2001; Bell \& Blackhurst, 1996; Lahm \& Nickels, 1999; Peterson, 1998).

(d) Standards are of great interest and concern in the current educational system (Alexander, 2002; Awbrey, 1995; Beach \& Lindahl, 2000; Cochran-Smith, 2003; Elmore \& Fuhrman, 1995; Ingvarson, 1998; Kirst, 1997; Sheldon \& Biddle, 
1998; Swain \& Pearson, 2003; Wiebe, Taylor, \& Thomas, 2000). Standards are perceived as a means to address problems of poor academic performance (Baker, Linn, \& Koretz, 2002; Campbell, Hombo, \& Mazzeo, 2000; Linn, 2000; Perie, Moran, \& Lutkus, 2005), as well as providing a linkage between research, policies, and practice (Hargreaves, 1999; U.S. Department of Education, 2006).

(e) Standards and competencies in AT are important to support the successful participation of students with disabilities in the general education system (Schrag \& Ahearn, 1998; Tindal, Heath, Hollenbeck, Almond, \& Harniss, 1998; Todis, 1996). Teachers need training in AT knowledge and skills to be able to meet and implement AT standards and competencies (Bausch \& Hasselbring, 2004; Lahm, \& Sizemore, 2002; Lange, McPhillips, Mulhern, \& Wylie, 2006; Puckett, 2004).

(f) The U.S. education system requires the use of rigorous research and EBP for educational decision-making and policy development (Odom, Brantlinger, Gersten, Horner, Thompson, \& Harris, 2005; U.S. Department of Education, 2006, 2007a \& b), however few studies document implementation of AT standards (Edyburn, 2002b; McNear, 2005; QIAT Consortium Leadership Team, 2000) or provide research on AT and EBP (Odom, Brantlinger, Gersten, Horner, Thompson, \& Harris, 2005; Paulsen, 2005; Schlosser \& Raghavendra, 2004).

(g) The literature on AT in education reveals much information and numerous studies involving individual needs (Behrmann \& Jerome, 2002; Boone \& Higgins, 2007; Calculator, 1999; Campbell, Milbourne, \& Dugan, 2006; Carey \& Sale, 1994; Hasselbring, \& Glaser, 2000; Hutinger, Johanson, \& Stoneburner, 1996; Johnston \& Evans, 2005; Kittel, DiMarco, \& Stewart, 2002; Lange, McPhillips, Mulhern, \& 
Wylie, 2006; Light, 1999; Phillips \& Zhao, 1993; MacArthur \& Cavalier, 2004;

Riemer-Reiss \& Wacker, 2000; Sax, Fisher, \& Pumpian, 1996; Todis, 1996). There is much literature available regarding AT and educator needs (Bausch \& Hasselbring, 2004; Chen, Wu, \& Chu, 2004; Derer, Polsgrove, \& Rieth, 1996; Dissinger, 2003;

Edyburn, \& Gardner, 1999; Feyerer, Miesenberger, \& Wohlart, 2002; Lahm, 2003;

Lee \& Vail, 2005; Maushak, Kelley, \& Blodgett, 2001; Michaels \& McDermott, 2003;

Paulsen, 2005; Riley, Beard, \& Strain, 2004; Soto, Muller, Hunt, \& Goetz, 2001;

Thompson, Lazarus, Clapper, \& Thurlow, 2004; Todis, 1996; Warger, 1998).

Unfortunately, there is little available in AT literature that focuses on system needs, either state or national, particularly with regard to standards and policies (American Speech-Language-Hearing Association, 1997; Bell, 2001; Bell \& Blackhurst, 1996; Lahm \& Nickels, 1999; QIAT Consortium Leadership Team, 2000; Smith \& Jones, 1999).

The scope of literature presented here, and the gaps in evidence, support the need for further study of the nature AT standards and competencies at state level, the level of evidence used to establish AT standards, and the degree of AT implementation at state level. While some studies identify the connection between individual AT use and student performance (Boone \& Higgins, 2007; Hutinger, Johanson, \& Stoneburner, 1996, Todis, 1996), connection between state AT standards, AT implementation, and student performance has not yet been researched. The relationship of state policies and procedures to student performance was, therefore, studied by comparing, across states, their levels of AT standards, evidence and implementation to the state performance assessments of students with disabilities. 


\section{CHAPTER 2}

\section{Methodology}

\section{Literature Review and Analysis}

A comprehensive AT literature search was conducted and relevant literature that met the stated criteria was organized into the framework of a conceptual model of AT standards and EBP. This comparison of AT standards and EBP has not yet appeared in the literature, and it lays a foundation for understanding how EBP can inform AT standards and competencies. Tables 3, 4, 5, 6, \& 7 present the results of the literature analysis. From this analysis and the questions it has raised, the following research questions were developed and used for this study:

1. What types of AT standards \& teacher competencies currently exist in the states' K-12 education systems in the United States?

2. What types \& rigor of evidence supports the state AT standards \& teacher competencies in the United States?

3. What degree of implementation is present for state AT standards \& teacher competencies?

4. What relationship exists between AT standards and teacher competencies, level of evidence rigor, and degree of AT implementation and special education student performance as measured by state reading and math assessments?

The null hypothesis for this study, therefore, states that there is no significant relationship between AT standards and teacher competencies, level of evidence 
rigor, and the degree of AT implementation and the performance of special education students as measured by state reading and math assessments.

\section{Data Collection}

To pursue answers to the research questions of this study, a survey process was determined to be most appropriate for data collection. Available surveys in AT were reviewed and determined inadequate for the purposes of this study. A researcherdesigned survey, therefore, was developed and piloted to ensure consistency and integrity of data. Items included on the survey were based upon AT literature, and they followed a method of coding standards and competencies according to Sweeny's organization of standards (Table 1), and Davies' continuum of evidence (Table 2). To ensure the fidelity of data to be collected, three specific procedures were followed: (1) development of the data-gathering instrument; (2) development of an accurate list of state department of education AT contacts; and (3) development of a telephone contact protocol for data gathering. Details of these three procedures are presented below.

\section{Survey Instrument}

Prior to the development of the survey, relevant AT literature was reviewed to determine if any survey instruments that currently exist that could be used or modified for the purpose of this study. Studies consulted included Bell (2001), Lahm (2000), Lahm \& Nickels (1999), and Zabala, Blunt, Carl, Davis, Deterding, Foss, et al. (2000). While each of these studies gathered and used data relating to AT standards and competencies, only one (Bell, 2001) gathered data from individual states, and this study primarily focused upon identification of AT use and needs assessment. More notably, none of the above studies involved specific assessment of evidence, current 
state AT standards or competencies, or degree of AT implementation. Based upon these findings, it was determined that an individualized survey instrument needed to be designed for use in the study.

Survey data sought was organized into three areas of AT: (1) types of AT standard or AT competency; (2) level of evidence for AT standard or competency, and (3) degree of AT implementation. The purpose for gathering data in these areas was to identify; (a) the nature of AT standards and competencies in each state, including standard and competency types, (b) the evidence that the standards and competencies is based on, and (c) the indicators of AT implementation (including guidelines, materials, inclusion in IEP and state testing, and inclusion in the state professional development system), in accordance with stated research questions.

Initial survey development involved drafting items and piloting those items to identify any points of possible confusion or ambiguity. Reviewers for the piloted survey included: (a) the master teacher at the Paul V. Sherlock Center, Debra Abruzzini; (b) the researcher's major PhD advisor, Dr. Susan Roush; and finally (c) the RI Dept. of Education AT supervisor, Dr. Phyllis Lynch. All feedback was utilized to clarify and improve the final survey document and letter of survey introduction (Appendix A).

\section{AT State Department of Education Contacts}

To ensure the accuracy of data, it was critical to identify the most current and appropriate individual AT contact for each state department of education. On the surface, this seems a relatively straightforward task, however it proved to be a very challenging task within this study. 
First, the websites of all fifty state departments of education (plus Washington, DC) were reviewed to determine if a specific individual was identified as the AT coordinator (or other leadership title involving AT, e.g. director or consultant). The RI Department of Education, Office of Special Populations supported this study, offering access through the Office of Special Populations' web page to links of all other state Dept of Education websites. The link to US State Special Education Departments, obtained through Dr. Lynch of the RI Department of Education, greatly aided in the identification of state AT contacts. In many cases, names, department telephone numbers, and email addresses were available. Approximately 50\% of contact information for the study was identified directly from this list.

Next, for those states that did not list the current AT contact for the state special education department, each state special education department was contacted by telephone or email to request the appropriate contact information. Regardless of the number of attempts needed, contact was continued until a definitive response was obtained for each state special education office. From these contacts, an additional $30 \%$ of states (approximately) supplied the necessary AT contact information for the study.

Finally, two national lists concerning AT in education were used in an effort to identify the appropriate contacts for the remaining $20 \%$ of states. These lists came from two national organizations: (1) the State Leaders in Assistive Technology in Education (SLATE), and (2) the Accessible Instructional Materials Consortium (AIM). Through these lists, the remaining state AT contacts were successfully 
identified. All contacts used for data collection in this study appear in Appendix C, Assistive Technology State Department of Education Contacts.

\section{Telephone Interview Protocol}

To ensure that each state AT contact would be ready to respond to the survey questions when contacted via telephone, the 3-page survey was forwarded

electronically to each state AT contact via email. The file was in PDF format, which retains all document formatting. Potential survey respondents were asked to review the form and gather relevant $\mathrm{AT}$ information from their state prior to participating in the telephone interview. All telephone contacts were made by a single researcher. Such a process eliminated concerns regarding possible differences in the interpretation of any descriptive responses. All questions were read to the state AT contacts orally, over the telephone, by the researcher, and specifically as they appeared on the survey. If respondents had questions regarding the meaning of any particular survey item, clarification was provided by the researcher consistent with the intent of the survey and the content of the AT field. All responses offered by respondents that went beyond the discrete data requested by the survey were noted on the original survey response sheet. This descriptive data was included in the analysis of this study. Fortythree states, plus Washington, D.C., completed the telephone survey with the researcher. Respondents were offered the option of receiving a summary of study results. All who answered positively were electronically forwarded a copy of the data summary.

Despite repeated attempts to speak directly with all state AT contacts (at least three calls were made in each case to non-respondents, as well as three email 
messages), a few states were not able to, or chose not to, complete the survey by telephone interview with the researcher. These states were given the alternative option of faxing the competed survey to the researcher. Seven states chose this option and returned completed surveys by fax.

The completion rate for the survey was $100 \%$. Data from every state in the United States, as well as data from Washington, D.C., was gathered and later analyzed $(\mathrm{N}=51)$.

\section{Special Education Student Performance Data}

In addition to survey data, publicly available data on the most recently available results of comprehensive statewide performance assessments at the time of the study were identified. The results available in 2007 (based upon 2006 school year assessments) were identified during the data-gathering period of this study on the U.S. Department of Education website (U.S. Department of Education, 2007a). Student performance data for school year 2006-2007 was not published at the time of data gathering and, therefore, could not be used in this study. The student performance data was identified for later comparison with the three predictor variables' data gathered in the national survey, in order to determine any statistical relationships between variables, using regression analysis.

\section{Data Analysis}

Data were organized according to state, survey item number, and factor group. The Statistical Package for the Social Sciences (SPSS) was used for data management, organization, and statistical analysis.

Descriptive Statistics 
Descriptive statistics concerning AT terminology, AT standards, AT

competencies, and AT implementation were calculated. These results are reported in Chapter 3, Results.

\section{Correlation Statistics}

Comparison of the states' data for the three predictor variables, (1) types of AT standard or AT competency, (2) level of evidence for AT standard or competency, and (3) degree of AT implementation, was made with the criterion variable, performance of each states' special education students on national grade 4 statewide assessments in reading and mathematics. To appropriately carry out the analysis, weighted formulas were designed to summarize the data of each predictor variable described above. The process followed in developing these summary formulas is presented below.

\section{Definition of Variables}

\section{Summary Predictor (Independent) Variables}

To capture the extent of current use of AT standards/competencies, degree of AT implementation, and level of AT evidence rigor, summary predictor variables were calculated. It was determined that the descriptive data related to each of the predictor variables would be combined using appropriate varying weights, in order to arrive at the summary variables. The weights assigned for each data item were determined according to the extent to which each item reflected Sweeny's (1999) and Davies' (1999) models, in order to accurately represent the extent to which AT was an integrated, valued, and specific construct in each state's educational system. Details of the process used to determine the three summary variables follow.

1. AT Standards and Competencies 
In accordance with the model identified by Sweeny (Table 1) in the literature review, this study defines AT standards and competencies in four specific areas: content, performance, curriculum, and delivery. The model defines content and performance standards for students and curriculum and delivery standards for teachers. As this study primarily concentrated on AT standards and competencies for teachers, greater weight was assigned for state-identified curriculum and/or delivery standards than for content and/or performance standards. Positive responses for content and/or performance items received the value of one, as these data were student-related. Positive responses for curriculum and/or delivery items received the value of five, as these data were teacher-related. There is little distinction in the literature between AT standards and AT competencies, therefore for purposes of determining weight, presence of AT standards or AT competencies in states were incorporated into one formula. States were also given credit for both AT standards and AT competencies, if each was reported present.

In summary, the predictor summary variable of AT standards and competencies was determined according to the following formula:

$($ Content Standard x 1) $+($ Performance Standard x 1) $+($ Curriculum Standard x 5) + $($ Delivery Standard x 5$)+($ Content Competency x 1$)+($ Performance Competency x 1) $+($ Curriculum Competency x 5) $+($ Delivery Competency x 5) $=$ Extent of State AT Standards and Competencies for Teachers. The highest possible score using this formula was 24 .

\section{AT Implementation}


The second predictor variable consisted of measurable indicators of state departments of education's AT implementation. These indicators were defined in two areas: (1) state AT implementation instructions; and (2) state AT professional development (PD). Measurable indicators of state AT implementation instructions were evidence of brochures, manuals, web-based information, or other formats that described how to use of AT in four areas of education: (a) the general education system, (b) the classroom, (c) state-wide testing, and (d) IEP development and implementation. The AT implementation indicators that were more general in nature and evidence required (identified as general use and classroom use), received the value of one and indicators that were more evidence specific (state-wide testing and IEP development) received a value of three, as the formula sought to give greater value to specifically defined state AT instructions. Also identified were four measurable indicators of state AT professional development: (a) AT PD recommended by the state, (b) AT PD required by the state, (c) state AT endorsement established for teachers, and (d) state AT certification established for teachers. Values of AT PD indicators were determined according to what degree they reflected state support or requirement of AT PD for educators. Values awarded to AT PD items were: (a) recommended $\mathrm{AT} \mathrm{PD}=3,(\mathrm{~b})$ required $\mathrm{AT} \mathrm{PD}=5$, (c) $\mathrm{AT}$ endorsement $=8$, and (d) AT certification $=10$.

In summary, the predictor summary variable of AT implementation was determined according to the following formula: 
$($ Gen Use $x$ 1) $+($ Class Use x 1) $+($ Test Use x 3$)+($ IEP Use x 3$)+($ Recommend AT PD x 3) $+($ Require AT PD x 5) $+($ AT Endorsement $\times 18)+($ AT Certification $x 10)=$ Degree of State AT Implementation. The highest possible score was 34.

\section{Level of Evidence Rigor}

In accordance with Davies' hierarchy of evidence earlier identified in Table 2, the third predictor variable included measurable indicators of varied levels of rigor in evidence used by states to develop their AT standards and/or competencies, and values were based upon extent of evidence rigor of each indicator measured in the survey. Values to the four indicators of evidence documentation used in the study are: (a) other sources of documentation $=1$, (b) professional reports $=2$, (c) professional articles $=5,(d)$ peer-reviewed published research $=10$.

In summary, the predictor summary variable of level of evidence was determined according to the following formula:

$($ Peer reviewed research x 10) $+($ Professional articles x 5) $+($ Professional reports x 2) $+($ Other x 1) $=$ Level of Evidence Rigor. The highest possible score was 18 .

\section{Criterion (Dependent) Variable}

The study was designed to analyze three predictor variables in comparison with the criterion (dependent) variable of the academic performance of students with disabilities, as measured nationally by state-wide assessments of reading and math for students who are served by special education (defined as those students who currently have IEPs). State-wide performance assessments are part of the national assessment system known as the National Assessment of Educational Progress (NAEP), conducted through the National Center for Educational Statistics (NCES), Institute of 
Educational Sciences (U.S. Department of Education, 2008). The student performance data used in this study was obtained through the US government website that publishes state performance assessment reports (U.S. Department of Education, 2007a).

Data for all nationally-identified subgroups are published each year, which includes data for students served by special education with IEPs. Data gathering for this study took place during late 2007 and early 2008, and nationally available student performance data from the states (school year 2006, posted in 2007) was used, which was the most current national data available to the study during the data-gathering period. While national performance data for students with disabilities was available for fourth and eighth grades, only fourth grade performance data was used in the regression analysis. This decision was based upon the fact that AT consideration in a student's IEP became required by law in 1997, and past educational practice indicates that legal mandates do not impact practice until a number of years after they are enacted. Educational literature started to reflect activity involving AT in the years 1999 - 2000, with a significant body of work following that period. Students in fourth grade in 2007, at ages 8 or 9 years, were born during the years 1997-1999 and therefore would have the greatest opportunity to benefit from the use of AT in their educational programs. For this reason, only fourth-grade performance data were used. Finally, while performance scores for students with disabilities were available for two levels, "at or above basic" and "at or above proficient", the "at or above basic" scores actually included the proficient scores. Therefore, it was determined that use of only 
"at or above basic" scores for the criterion (dependent) variables in reading and math were necessary for the study analysis.

\section{Regression Analysis}

Multiple regression analysis examined the relationship between student performance (in reading and mathematics) and the three predictive variables (type of standard or competency, level of evidence, and degree of implementation). The summary formulas described above were applied for the regression analyses. All regression results and correlation statistics are reported in Chapter 3, Results. 


\section{Institutional Review Board Waiver}

The URI Division of Research and Economic Development, Institutional Review Board on Human Subjects (IRB), declined to review this study, as it determined that the study did not need IRB approval since the required data was archival in nature and not data from human subjects. The study used information available as public record. 


\section{CHAPTER 3}

Results

The purposes of this study were to identify (1) the type and extent of AT standards \& teacher competencies that are approved and used in state K-12 education systems, (2) the nature and rigor of evidence used for these standards \& competencies,

(3) the extent of state AT implementation through state education departments, and (4) the relationship of factors (1), (2), and (3) with national performance measures for students with disabilities. The data needed to address these purposes were gathered from the state education departments of the 50 US states plus the District of Columbia. For ease of presentation, these 51 data sources are referred to collectively as "states." The data gathered is described in Chapter 2, Methodology, and was documented via the researcher-designed survey tool (Appendix A). Initial data collection occurred through review of the state education department websites. As anticipated, this data source was not adequate to gather complete data, and direct contact with states' AT coordinators or designees was undertaken to secure the data. Contact occurred through telephone, email and fax. Of the 51 states, all 51 provided data yielding a $100 \%$ response rate.

Study results are presented in two sections: (1) Descriptive Analyses and (2) Regression Analyses.

\section{Descriptive Analyses}

Descriptive analyses were used to address the first three study purposes identified in the first paragraph of Chapter 3. The study survey was designed to gather 
distinct data on AT standards and AT competencies from each state, and the descriptive results are reported here in those separate categories. Survey data revealed that very few states have either officially recognized or approved AT standards or AT competencies for teachers. A large majority of states, in comparison, reported a variety of AT implementation activities. These descriptive results are presented in detail below.

\section{AT Terminology}

Of the 51 states, 40 states $(80 \%)$ officially did not use either of the terms, "AT standards" or "AT competencies". Of the remaining 11 states, three $(6 \%)$ used the term "AT standards", three (6\%) used the term "AT competencies", three $(6 \%)$ considered the terms to have the same meaning, and one (2\%) considered the terms to have different meanings. One state (NY) did not respond to this question.

\section{AT Standards}

Of the 51 states, three states $(6 \%)$ reported having AT standards that were approved by their state department of education. States' responses, however, about the type of standards that exist (in accordance with Sweeny's model of educational standards), and whether these standards exist independently or are integrated within other sets of standards yielded three additional states that have AT standards. This

brought the total number of states having AT standards to six (12\%). The frequency by standard type (as defined by Sweeny) and the degree of integration with other standards (independent, integrated, or a combination of independent and integrated) for these six states are provided in Table 8. 
Table 8

Types of AT Standards Existing in US $(N=6)$

Intended

User Standard Type Total $(\mathrm{N}=6)$ Independent Integrated Indep \& Integ

\begin{tabular}{|l|l|l|l|l|l|}
\hline \multirow{3}{*}{ Student } & Content & $3(50 \%)$ & $1(17 \%)$ & $2(33 \%)$ & $0(0 \%)$ \\
\cline { 2 - 6 } & Performance & $2(33 \%)$ & $0(0 \%)$ & $1(17 \%)$ & $1(33 \%)$ \\
\hline \multirow{2}{*}{ Teacher } & Curriculum & $3(50 \%)$ & $0(0 \%)$ & $3(50 \%)$ & $0(0 \%)$ \\
\cline { 2 - 6 } & Delivery & $3(50 \%)$ & $1(17 \%)$ & $2(33 \%)$ & $0(0 \%)$ \\
\hline
\end{tabular}

While the great majority of states do not have officially approved AT standards, eleven individual states use AT standards developed by other professional organizations as guidelines for their state's AT use. Of these eleven states, four (8\%) reported using the AT standards developed by the National Association of State Directors of Special Education (NASDSE) and three states (6\%) reported using the Council for Exceptional Children's (CEC) AT standards. Four states (8\%) use the Quality Indicators for Assistive Technology (QIAT) which are not standards but rather were developed as professional guidelines. One state $(2 \%)$ reported using the Wisconsin Assistive Technology Indicators (WATI), and one state (2\%) used its own instructional technology standards, which included AT components.

Concerning how the AT standards could be accessed by interested parties (e.g. website, print, or other), two of the six states previously identified as having AT standards posted them on their state website. None used print publication for AT standards. Two of the six states used other means of information sharing, such as professional development courses \& telephone information. One of the six states 
reported using all means listed on the data collection survey (website, print publications, and other means of information sharing) to provide access to AT standards, and one of the six states did not indicate how they share their AT standards information. Concerning the availability of information about the development of AT standards, four states $(8 \%)$ had information available that explains the AT standard development process. The means for sharing this information included websites for two states (4\%), other (not web or print) for one state (2\%), and all sources (web, print, \& other) used in one state (2\%).

Regarding information available about evidence used in the development of AT standards, only two states (4\%) provided documentation of the evidence on which their AT standards are based. One of these states referenced professional reports and other information, while the other referenced a professional website that contains professional reports. None of the respondents identified using highly rigorous evidence (as per Davies, 1999) in the form of published research for standards development, or articles from professional publications to document evidence rigor.

\section{AT Competencies}

As described earlier in the literature review, there is confusion in the field concerning the differences between standards and competencies. Most publications that describe standards or competencies do not discriminate between the two; therefore, Sweeny's model of educational standards was used in this study to classify the types of AT competencies as well as AT standards. Five states (10\%) reported having state-approved AT competencies and those competencies existed in the four classification areas. One additional state, while not reporting having state-approved 
competencies, did provide AT competency data, bringing the total number of states having AT competencies to six (12\%). Table 9 illustrates the frequency of both competency type and nature of integration.

Table 9

Types of AT Competencies Existing in US $(N=6)$

Intended Competency

User Type Total $(\mathrm{N}=6) \quad$ Independent Integrated Indep \& Integ

\begin{tabular}{|l|l|l|l|l|l|}
\hline Student & Content & $2(33 \%)$ & $0(0 \%)$ & $2(33 \%)$ & $0(0 \%)$ \\
& Performance & $2(33 \%)$ & $0(0 \%)$ & $2(33 \%)$ & $0(0 \%)$ \\
\hline Teacher & Curriculum & $6(100 \%)$ & $3(50 \%)$ & $3(50 \%)$ & $0(0 \%)$ \\
& Delivery & $6(100 \%)$ & $4(67 \%)$ & $2(33 \%)$ & $0(0 \%)$ \\
\hline
\end{tabular}

Similar to the AT standards, most states do not have specific AT competencies that had been officially accepted or supported by the state department of education. However, five states (10\%) indicated that they used other professional sources of AT competencies as guidelines within their state for AT use. Two of the five states (4\%) reported using competencies from NASDSE. One of these states, as well as a second state (4\%) reported using the QIAT indicators as AT guidelines for educators. One state $(2 \%)$ referenced the use of WATI materials for guidance in AT, and one state (2\%) reported use of Universal Design for Learning Principles (UDL) as primary guidance for its state AT guidelines and expectations.

Concerning how the AT competencies in their state could be accessed, two states (4\%) have AT competencies that are accessible through the web. Another two (4\%) have print information available on AT competencies. Only one state (2\%) 
reported using both web \& print information, and one state (2\%) reported using web, print and other means (e.g. by telephone or through professional development activities).

Concerning the provision of public information about how the AT competencies were developed, of the 51states, three (6\%) reported having information available about the development of their AT competencies for teachers. In a different survey question, however, four states $(8 \%)$ reported having this information available. The choice of presentation mechanism for this information revealed that one state (2\%) used only the web, one state $(2 \%)$ used only print, one state $(2 \%)$ used only other means, and one state $(2 \%)$ used both web \& other means of information sharing.

Concerning the evidence on which AT competencies were based, four states $(8 \%)$ reported having this information. One state's $(2 \%)$ evidence was in the form of professional articles. Three states (6\%) had evidence that is less rigorous by Davies' scale (identified as “other" evidence). No state provided evidence for AT competencies in the form of more rigorous peer-reviewed research or professional reports.

When AT competencies and AT standards are considered together, three states (6\%) reported having both AT standards and AT competencies. A total of nine unique states, $18 \%$ percent of those surveyed, reported having either AT standards or AT competencies that are officially recognized by their state department of education. Descriptive statistics of mean, standard deviation, and range for AT standards and AT competencies together (Table 12), as determined through SPSS, appear following reported data on AT implementation below. 


\section{AT Implementation}

The next area addressed on the survey was implementation of AT by state departments of education, which the survey measured in two specific categories; state AT instructions and state AT professional development (PD). Four states did not respond to items in this section. Of the forty-seven states that did provide responses in this section, the most common level of instructions provided by states were AT instructions identified as general in nature, and intended for all teachers in the state's education system (98\%). High levels of instructions were also provided for AT use in classrooms (83\%), AT use in state-wide testing (81\%), and AT consideration in IEP development and implementation $(81 \%)$.

The second measured area of AT implementation was state PD. General PD implementation was reported to be high (94\%), however implementation levels significantly dropped on questions that specifically asked asked about level of commitment required for PD. Thirty-six percent of state departments recommended AT PD, but only $6 \%$ required AT PD in some form for state educators. Furthermore, the percentage of states with established AT endorsement or certification requirements for K-12 educators was $4 \%$ or less. Table 10 provides detail on the types of state AT instructions and PD reported in the various states. 
Table 10

AT Implementation in the Education System - Instructions and Professional Development $(N=47)$

\begin{tabular}{|c|c|}
\hline Implementation Type & $\begin{array}{l}\text { Frequency }(\%) \\
\mathrm{N}=47\end{array}$ \\
\hline Survey Item 3a. State Instructions for AT Implementation? & $47(100 \%)$ \\
\hline 3a.a. Use in the general education system & $46(98 \%)$ \\
\hline 3a.b. Use in the classroom & $39(83 \%)$ \\
\hline 3a.c. Use in statewide testing & $38(81 \%)$ \\
\hline 3a.d. Use in IEP development & $38(81 \%)$ \\
\hline Survey Item 3b. State Professional Development (PD) in AT? & $44(94 \%)$ \\
\hline 3b.a. $\mathrm{PD}$ in $\mathrm{AT}$ recommended by state $\mathrm{DOE}$ & $17(36 \%)$ \\
\hline 3b.b. PD in AT required by state DOE & $3(6 \%)$ \\
\hline 3b.c. State AT endorsement for educators exists & $2(4 \%)$ \\
\hline 3b.d. State AT certification for educators exists & $1(2 \%)$ \\
\hline
\end{tabular}

Additionally, most states self-reported having a wide variety of other AT implementation activities beyond those specifically identified in the coded survey questions. Forty-nine of the 51 states surveyed had at least one additional implementation activity beyond those included in the survey data questions. Summary of the frequencies of the other state AT implementation activities are provided in Table 11. 
Table 11

Other State AT Implementation Activities (N=49)

Implementation Activity

\begin{tabular}{|c|c|}
\hline 1. Regional centers with AT services & $28(57 \%)$ \\
\hline 2. Annual AT conference & $24(49 \%)$ \\
\hline 3. AT loan library & $22(45 \%)$ \\
\hline 4. AT in other state conferences & $19(39 \%)$ \\
\hline 5. State $\mathrm{DOE}^{*} / \mathrm{AT}$ trainers & $19(39 \%)$ \\
\hline 6. AT teams in LEAs** & $16(33 \%)$ \\
\hline 7. UDL/AT initiative & $15(31 \%)$ \\
\hline 8. AIM $^{* * *}$ consortium $(\mathrm{NIMAS} * * * *)$ & $14(29 \%)$ \\
\hline 9. AT infused across other state depts. & $13(27 \%)$ \\
\hline 10. On-line AT training & $13(27 \%)$ \\
\hline 11. AT summer camp or institute & $13(27 \%)$ \\
\hline 12. AT specialists in LEAs & $13(27 \%)$ \\
\hline 13. Use QIAT indicators & $9(18 \%)$ \\
\hline 14. RESNA $* * * * *$ certification supported & $8(16 \%)$ \\
\hline 15. Higher Ed AT certification & $8(16 \%)$ \\
\hline 16. State AT education services through TechACT project & $8(16 \%)$ \\
\hline 17. NASDSE standards training & $7(14 \%)$ \\
\hline 18. AT searchable database & $6(12 \%)$ \\
\hline 19. State purchase/reimbursement program & $5(10 \%)$ \\
\hline 20. Specialized AAC training & $5(10 \%)$ \\
\hline 21. Ed. credential program includes AT & $4(8 \%)$ \\
\hline 22. CSUN certification & $4(8 \%)$ \\
\hline 23. Initial AT conference 2008 & $2(4 \%)$ \\
\hline 24. Televised AT courses & $1(2 \%)$ \\
\hline
\end{tabular}

*Department of Education **Local Education Authorities ****National Instructional Media Accessibility Standard *****Rehabilitation Engineering Association of North America
$\mathrm{N}=49$ Frequency $(\%)$

$28(57 \%)$

$24(49 \%)$

$22(45 \%)$

$19(39 \%)$

$16(33 \%)$

$15(31 \%)$

$14(29 \%)$

$13(27 \%)$

$13(27 \%)$

$13(27 \%)$

$13(27 \%)$

$9(18 \%)$

$8(16 \%)$

$(16 \%)$

$5(10 \%)$

$5(10 \%)$

$4(8 \%)$

$4(8 \%)$

$2(4 \%)$

$1(2 \%)$
***Accessible Instructional Media 
Descriptive statistics of mean, standard deviation, and range for AT implementation, as determined through SPSS, appear in Table 12. In addition, Table 12 includes these same descriptive statistics for the other study predictor variables, AT standards and competencies and level of evidence rigor, and the study criterion variables of national $4^{\text {th }}$ grade reading performance and national $4^{\text {th }}$ grade math performance for students with disabilities.

Table 12

Descriptive Results for Predictor and Criterion Variables of U.S. States $(N=51)$

Variable $\quad$ Mean Standard Dev. Range of Responses $\quad$ \# States $=0$

\begin{tabular}{|l|l|l|l|l|}
\hline $\begin{array}{l}\text { AT standards/ } \\
\text { competencies }\end{array}$ & $\begin{array}{l}1.96 \\
\text { (of } 24)\end{array}$ & 5.012 & 0 to 24 & 42 \\
\hline $\begin{array}{l}\text { AT } \\
\text { implementation }\end{array}$ & $\begin{array}{l}7.88 \\
\text { (of } 34)\end{array}$ & 5.226 & 0 to 34 & 2 \\
\hline $\begin{array}{l}\text { Level of } \\
\text { evidence rigor }\end{array}$ & $\begin{array}{l}.25 \\
\text { (of } 18)\end{array}$ & .956 & 0 to 6 & 46 \\
\hline $\begin{array}{l}4^{\text {th }} \text { grade } \\
\text { reading }\end{array}$ & $\begin{array}{l}36.08 \\
\text { (of } 100)\end{array}$ & 8.586 & 15 to 54 & 0 \\
\hline $\begin{array}{l}4^{\text {th }} \text { grade } \\
\text { mathematics }\end{array}$ & $\begin{array}{l}58.49 \\
\text { (of } 100)\end{array}$ & 11.512 & 20 to 83 & 0 \\
\hline
\end{tabular}

The mean of AT implementation was significantly greater than the mean of either AT standards and competencies or level of evidence rigor. Florida scored highest (24) for AT standards and competencies. Wisconsin scored highest (34) for AT implementation. Utah scored highest (6) for level of evidence rigor. The number of states responding positively to AT implementation survey questions $(\mathrm{N}=47)$ was much greater than the number of states responding positively to AT standards/competencies questions $(\mathrm{N}=9)$ or to level of evidence rigor questions $(\mathrm{N}=5)$, which likely affected the low mean scores. An extremely low mean score was 
determined for level of evidence rigor (.25), indicating very few states having either rigorous evidence for AT standards or competencies, or very few having any evidence at all. It was interesting to see that the mean national reading performance score (36.08) was much lower than the mean national math score (58.49) for students with disabilities. Other information that would inform this study on these performance score differences was not available.

\section{Regression Analyses}

Multiple regression analysis was used to determine the relationship between the three predictor (independent) variables and the criterion (dependent) variable of student performance. Two separate regression analyses were conducted. The first regression used the national $4^{\text {th }}$ grade reading scores for students with disabilities as the dependent variable, and the second regression used the national $4^{\text {th }}$ grade math scores for these students as dependent variable. The multiple regressions performed were: (1) three summary predictor variables and reading performance, and (2) three summary predictor variables and math performance. All statistical analyses were conducted using the computer-based Statistical Package for the Social Sciences (SPSS), SPSS 10 for Mac OS X version.

Results of these multiple regression analyses are presented in Correlations: Reading and Math (Table 13), Model Summaries: Reading and Math (Table 14), and Analyses of Variance: Reading and Math (Table 15). 


\section{Correlations: Reading and Math}

Using the survey data and national performance data, Pearson correlations were conducted using SPSS. Results are presented in Table 13.

Table 13

Pearson Single Tailed Correlations between Predictor Summary Variables (AT

Standards/Competencies, AT Implementation, and Level of Evidence) and Criterion Variables $\left(20064^{\text {th }}\right.$

Grade Reading and Math, at or above basic proficiency)

Correlation (Pearson) $\quad 4^{\text {th }}$ Gr. Read $4^{\text {th }}$ Gr. Math AT Stds/Cmps AT Imple AT Evidence

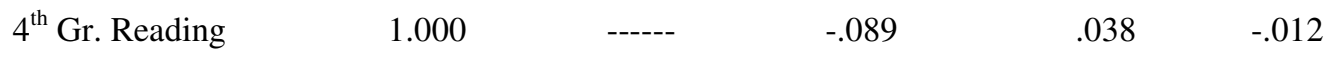

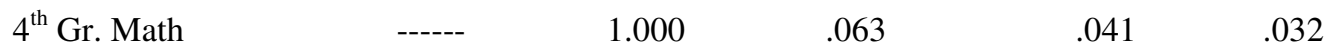

$\begin{array}{llllll}\text { AT Stds/Cmps } & -.089 & .063 & 1.000 & .145 & .403 *\end{array}$

$\begin{array}{llllll}\text { AT Imple } & .038 & .041 & .145 & 1.000 & -.130\end{array}$

\begin{tabular}{llllll} 
AT Evidence & -.012 & .032 & $.403 *$ & -.130 & 1.000 \\
\hline
\end{tabular}

$* \mathrm{p}<.05$ ( single tailed t-test)

There were very small, non-significant, correlations between $4^{\text {th }}$ grade reading performance and the three independent predictor summary variables. The correlations between $4^{\text {th }}$ grade math performance and the three independent predictor summary variables were also very small and non-significant Correlations among the predictor variables range from +.403 to -.130 , with the correlation between AT standards/competencies and AT evidence significant at $\mathrm{p}<.05$. As regression analyses were carried out separately for reading and math, a correlation analysis between reading and math scores was not conducted, as evidenced in the above table. 


\section{Model Summaries: Reading and Math}

Table 14

Model Summaries for Correlations between Predictor Variables (AT Standards/Competencies, AT Implementation, and Level of Evidence) and Criterion Variables (2006 $4^{\text {th }}$ Grade Reading and Math, at or above basic proficiency)

\begin{tabular}{lllll} 
Model & $\mathrm{r}$ & r square & adjusted r sq. & stand. error est. \\
Reading & .110 & .012 & -.051 & 8.802 \\
Math & .072 & .005 & -.058 & 11.843 \\
\hline
\end{tabular}

From Model Summary Table 14, the multiple correlation coefficient $r=.110$ measures the degree of relationship between actual values and predicted values of $4^{\text {th }}$ grade reading performance for students with disabilities. As the predicted values are obtained as a linear combination of AT standards/competencies, AT implementation, and level of evidence, the coefficient value of .110 indicates a very weak relationship between reading performance and the three independent variables. The coefficient of determination (r-square) shows that only $1.2 \%$ of the variation in $4^{\text {th }}$ grade reading scores can be accounted for by the estimated sample regression equation that uses AT standards/competencies, AT implementation, and level of evidence as the independent variables. The adjusted r-square, which accounts for the degrees of freedom lost in the process of estimating the regression parameters, for $4^{\text {th }}$ grade reading scores is -.051 , which further indicates the weakness of the relationship between this criterion variable and the three predictor variables. The standard error of the estimate, measuring overall accuracy of the estimated sample regression equation, for $4^{\text {th }}$ grade reading was found to be 8.802 . This indicates that, on average, the predicted values for $4^{\text {th }}$ grade reading performance could vary by plus or minus 8.802 points about the 
regression equation for each value of the three independent variables during the sample period, which is a relatively high degree of variation.

Regarding $4^{\text {th }}$ grade math performance of students with disabilities, Model Summary Table 14 reports the multiple correlation coefficient $r=.072$. This coefficient indicates an even weaker relationship between math performance and the three independent variables than in the previous model summary for reading. The coefficient of determination (r-square) is extremely small at .005 , which translates to indicate that only $0.5 \%$ of the variation in $4^{\text {th }}$ grade math scores can be accounted for by the estimated sample regression equation that uses the three independent variables. The adjusted $r$-square for $4^{\text {th }}$ grade math scores is -.058 , further underlining the significantly weak relationship between this criterion variable and the three predictor variables. The standard error of the estimate for $4^{\text {th }}$ grade math was reported as 11.843 , meaning that, on average, the predicted values for $4^{\text {th }}$ grade math performance could vary by plus or minus 11.843 points about the regression equation for each value of the three independent variables during the sample period, a higher degree of variation than found for reading. 


\section{Analyses of Variance: Reading and Math}

Table 15

Analysis of Variance (ANOVA) of Predictor Variables (a.) for Criterion Variables (b. \& c.)

\begin{tabular}{|c|c|c|c|c|c|c|}
\hline Variable & Mode & ss & $\mathrm{df}$ & $\mathrm{ms}$ & $\mathrm{F}$ & Sig. \\
\hline \multirow[t]{3}{*}{ Reading } & Regression & 44.270 & 3 & 14.757 & .190 & .902 \\
\hline & Residual & 3641.416 & 47 & 77.477 & & \\
\hline & $\underline{\text { Total }}$ & 3685.686 & 50 & & & \\
\hline Variable & Mode & ss & $\mathrm{df}$ & $\mathrm{ms}$ & $\mathrm{F}$ & Sig. \\
\hline \multirow[t]{3}{*}{ Math } & Regression & 34.132 & 3 & 11.377 & .081 & .970 \\
\hline & Residual & 6592.613 & 47 & 140.268 & & \\
\hline & Total & 6626.745 & 50 & & & \\
\hline
\end{tabular}

a. Predictors (Constant): AT Standards/Competencies, AT Implementation, Level of Evidence

b. Criteria (Dependent): 2006 Gr. 4 Reading at/above basic competence

c. Criteria (Dependent): 2006 Gr. 4 Math at/above basic competence

The analysis of variance (ANOVA) was performed in order to test the significance of the model for prediction of total variation of the $4^{\text {th }}$ grade reading and $4^{\text {th }}$ grade math scores of students with disabilities in relation to the three independent variables. For reading, using a significance level of .05, an F value of .190 is not significant, resulting in a failure to reject the null hypothesis, since results indicate that chance is the best explanation for the differences found related to reading.

For the regression analysis looking at $4^{\text {th }}$ grade math scores using a significance level of .05 , an $\mathrm{F}$ value of .081 is not significant, again resulting in a failure to reject the null hypothesis, as chance is also the best explanation for the differences found related to math. 


\section{CHAPTER 4}

\section{Discussion}

The discussion is organized according to the same primary topic areas as the study results, following the headings of AT literature, AT terminology, AT standards and competencies, AT implementation, and regression analyses, with a final summary of major findings.

\section{AT Literature}

Study of literature in the areas of AT, educational technology, and education revealed a paucity of evidence, particularly rigorous evidence, available concerning AT standards and competencies for teachers. This lack of literature points to a field that appears to not understand, value or benefit from the paradigm of research, a disappointing finding. The field of AT needs to grow beyond its reliance on the least rigorous forms of evidence by developing and supporting practitioners and researchers to increase their knowledge of EBP, expand the available evidence, and apply it in educational practice. Opportunities that encourage research to determine the evidence that supports student success through the use of AT, and the linkage of EBP to AT standards and competencies, is vitally important for the continued growth in the AT field.

\section{AT Terminology}

When considering results concerning states' use of AT terms, the most notable finding showed that while the requirement for AT to be considered in the IEP process for every student with a disability was established over 10 years ago, there was no official recognition or use of the terms "AT standards" or "AT competencies" by $80 \%$ 
of the state departments of education. These terms are not part of the official state educational vocabulary. Reasons for this situation are unclear, however it may relate to the fact that AT standards and AT competencies are not requirements of any present laws and therefore have not become necessary priorities for the state departments of education, as was identified earlier in the AT literature (Blackburn \& Edyburn, 2000). When legal mandates are required of states (i.e., NCLB), perhaps other plans and priorities are set aside in order to address these mandates. Even with the requirement that AT be considered in IEPs, development of the AT standards and competencies that teachers need in order to competently and successfully consider AT for their students with disabilities appears still to be in its infancy, as evidenced by lack of use of these specific AT terms.

\section{AT Standards and Competencies}

Further evidence of the limited attention state departments of education give to AT standards and competencies was found from this section of the survey. Only six states reported AT standards in place and six states reported having AT competencies. Of these, three states reported both standards and competencies, yielding nine unique states in the study having AT standards and/or AT competencies. While this is a small sample, it is interesting to note that for those with AT standards, the distribution was relatively equal between the number that have student-focused standards and the number that have teacher-focused standards in AT (Sweeny, 1999). For AT competencies, all six states reporting competencies had them in both of the identified areas concerning teachers - curriculum and delivery (Sweeney, 1999). Two of these states had competencies for students. Four states with AT competencies, however, 
had only teacher competencies and not student competencies. The study results showing that more states focused on teacher competencies rather than student competencies stand in contrast to the historical development of standards in educational technology. In this latter field, student-focused standards (now used nationwide) developed first, followed by teacher-focused standards that developed to support achievement of the student standards (International Society for Technology in Education, 2007). The findings of this study show that rather than student standards being prerequisite to teacher standards in AT, these two types of standards seem to be developing simultaneously, and it is not clear if there is a specific relationship between the two, in comparison to the relationship between student and teacher technology standards in educational technology identified above.

\section{Integrated or Independent Standards}

Another aspect of states' AT competencies investigated in this study was their structure as either integrated or independent standards. This was important because of the traditional difference in purpose between general education and special education. Integrated standards were defined as those that appear as part of general or contentarea competencies. General educators are responsible for helping all students to achieve to the best of their abilities, and for teaching the general curriculum in a manner that benefits the whole class, and are more likely to be affected by broader, integrated standards. Special educators must address the wide variation in students' needs and abilities, based upon the specific diagnosis for each child that qualifies them to receive special educational services, and are more likely to be affected by specialized, independent standards. AT standards that are integrated would, by 
definition, impact general education teachers. The ratio of independent teacher AT competencies to integrated teacher competencies in this study was relatively equal, however for AT standards, the typical method of organization was integration within other sets of standards rather than existing as separate AT standards for educators or students. This finding is consistent with the increasing popularity of the principles of Universal Instructional Design (UID) (Silver, Bourke, \& Strehorn, 1998) and the principles of Universal Design for Learning (UDL) (Center for Applied Special Technology; CAST, 2001), both of which advocate for expanding teaching methodologies so that all students including students with disabilities, students with diverse learning needs, and students in general, have equal access to classroom teaching and learning (Pliner \& Johnson, 2004). This approach is consistent with the requirements of NCLB. Nationally in education, there is movement toward establishing more global standards and competencies for teachers, rather than specialized ones (Baker \& Linn, 1997; Education World, 2008). Many states have global beginning teacher standards for all initially certified teachers. When specific teacher standards or competencies are integrated within basic or general teaching standards, they have the potential to impact a large percentage of teachers. This integration, however, may potentially reduce the specificity and customization of required standards/competencies (Reigeluth, 1997). When specific teacher standards or competencies exist separately, to address specialized areas of need, expectation of greater specification of required knowledge and skills is possible, however, significantly fewer educators are impacted. Only nine states have actually developed AT standards or competencies, and it appears from the study results that states have 
not yet decided which method of organizing AT standards or competencies would best serve their needs, or, more globally, if states should establish any AT standards or competencies at all. As indicated earlier, AT standards and competencies are not legally mandated in education. When standards and competencies are legally mandated, there is much less uncertainty. The relationship between legal requirements concerning AT, AT standards and competencies, and other legal requirements concerning standards and competencies is again identified as an important area deserving further study.

\section{Feature Matching and Clinical Factors in AT}

In AT, the importance of specification of knowledge and skills is evidenced in the concept of feature matching (Riemer-Reiss \& Wacker, 2000), which identifies the specific features an individual needs to carry out a particular function, and matches these features with the unique features of AT. The concept of proper feature matching is basic to the effectiveness of AT. The importance of clinical AT factors, including instructor and user competence, user choice, system support, and device matching, have been identified as important components for successful AT use (Hutinger, Johanson, \& Stoneburner, 1996; Riemer-Reiss \& Wacker, 2000; Todis, 1996). The concept of EBP certainly emphasizes the importance of both research-based and clinically-based evidence for determining best practices (Hargreaves, 1999; Sackett, Rosenberg, Gray, Haynes, \& Richardson, 1996). This study showed that while a large number of states across the nation carried out AT implementation through statedelivered instructions to educators (Table 10) and through other AT implementation activities (Table 11), there is little evidence that current AT implementation is based 
upon any evidence-based standards (4\% of all states) or competencies ( $8 \%$ of all states). Of the thirteen states with highest AT implementation scores in the areas identified in this study, only four states reported having either AT standards or competencies that were approved by the state department of education. This study was not designed to gather detailed information about the clinical aspects of states AT implementation, which does limit the conclusions that can be drawn, as a stronger measure of the impact of AT standards and competencies would likely be through research that included factors of practice, following what was described by Hargreaves (1999) as "evidence-informed" practice. As preliminary research, however, between the areas of AT and EBP, the study does offer new direction and opportunities for further research into these areas.

\section{Profession-based AT Standards}

Clearly defined AT standards or competencies already exist from a number of professional, education-related organizations and 11 of 51 states reported use of external AT standards, rather working to develop their own. The professional AT competencies most commonly cited were from the National Association of State Directors of Special Education (NASDSE) or from the Council for Exceptional Children (CEC). Both sets of standards were developed through expert opinion studies, which is identified as relatively low in rigor of evidence according to Davies' hierarchy. While not highly rigorous, the presence of such evidence is certainly preferable to having no evidence.

Potential benefits for states using existing professional AT standards or competencies include the fact that these standards/competencies have already been 
screened by experts, and such screening implies at least a certain level of rigor.

Potential drawbacks to the use of AT standards or competencies from professional organizations include the concern that these professional standards/competencies could be too specific to the organization's unique purpose and perspective and not broad enough to address the full needs of the special education community, which includes a wide range of various professionals. Clarifying the differences in student outcomes when the two approaches (i.e. state-developed versus adoption of existing standards) are used would be valuable. Further research would be needed to achieve such clarification.

\section{Sharing Information on AT Standards and Competencies}

Information concerning how states publicize their AT standards/competencies was also gathered in this study. This is of interest because teachers need appropriate access to information about standards in order for those standards to be implemented. Again, because there were a limited number of states with AT standards or competencies, there is limited data to consider. For those states with information to share, an equal distribution between web access and print access was noted. It is surprising that not all states with AT standards/competencies use the web as primary means to distribute this information for the broadest reach to their communities. This could reflect a lack of technical capabilities, resources, or supports in states, or a true preference for use of print format for certain informational areas. It is also possible that there could be parallels between a state's capacity to support a website and their capacity to support AT in the curriculum. Further study is needed to explore these possible relationships. 


\section{Evidence-based Standards and Competencies}

While the data discussed so far may be considered of relative interest, investigating the evidence used to develop AT standards or competencies was the primary focus. One-third of states reporting AT standards and two-thirds of states reporting AT competencies cited supporting evidence. While there is a dearth of states that have AT standards or competencies, it is encouraging that at least some of those states used evidence in developing their standards and competencies. For the rest of the states, it is unclear whether evidence is not used because it is so scarce in the literature, or if policy personnel do not recognize or value systematically developed evidence. Since the US educational system requires the use of evidencebased practices, this deficiency in the documentation of rigorous evidence in these areas of AT should be of significant concern to the field. Traditionally, the focus in special education has been on practical classroom applications that will assist and support success for students with disabilities. While such applications are certainly important, speculation suggests that perhaps this priority has produced a field without sufficient background or experience with scientific evidence methods. Indeed, there has been a recent call to increase the level and rigor of evidence in the field of special education (Council for Exceptional Children, 2008; Odom, Brantlinger, Gersten, Horner, Thompson, \& Harris, 2005). Responding to this challenge will require changes in teacher preparation and professional development opportunities, specifically including more coursework and learning experiences that incorporate scientific research methods and a clearer understanding of EBP.

\section{AT Implementation}


In contrast to the paucity of AT standards and competencies, states are providing a significant amount of AT information. Interestingly, the practice of AT implementation does not appear to be dependent upon or linked to AT standards or competencies. Statewide, standards for student performance and competence are required components of the national education agenda, and teacher quality is determined in relation to students' achievement of standards. Standards provide states with measures of performance consistency, at least, at the most basic levels. This study reveals that the great majority of states are either in the very earliest stages of establishing such levels of expected performance in AT, or are not considering the establishment of AT standards or competencies. While general educational technology standards are broadly accepted by states and are providing guidance for teacher competency expectations, it appears that AT is not being equally considered. The long-term impact of a lack of AT standards or competencies at the state level on teacher preparation, and on students with disabilities is unknown. All in the field, however, should be concerned about this inequity.

While the number of states who have approved AT standards or competencies is small, a high percentage of these states report requiring some form of AT PD for their K-12 educators. These results suggest that it is likely when specific standards or competencies are established, state systems for PD acknowledge and include it in their expectations and requirements for teachers. The wide range of type and vigor of these AT implementation activities is notable (see Table 11). A related and interesting pattern revealed by the data in this study showed that the majority of states have less rigorous expectations for teachers in AT, and that as the level of required, rigorous PD 
went up, the number of states implementing required PD in AT went down. These findings suggest (1) a possible connection between teacher PD and the presence of standards or competencies in the education system and (2) a possible connection between degree of instructional rigor or specificity and amount of required PD. These results should be of interest to the fields of AT and education. The study identifies an inverse relationship between rigor and requirement; stated differently, that the more specific and rigorous the requirements, the fewer the states having such requirements. If this relationship holds true beyond this study, the implications to the field of education would be great. Studies exploring the connection between standards/competencies and teacher PD, examining the rigor of PD offerings, and identifying the relationship between level of rigor, teacher preparation, and program expectations would provide important data for use in making sound decisions about the structure and content of teaching programs \& state PD requirements, particularly as related to AT.

As previously stated, AT implementation activities do not appear to be driven by AT standards or competencies since so many more states have the former, but not the latter. The impact of legal requirements (i.e., NCLB, IDEA, NIMAS) appear to have greater influence on AT than states' needs or expectations for AT standards or competencies. The inclusion of AT in various laws apparently supported growth of AT implementation, but did not support development of AT standards or competencies, which many might consider as "putting the cart before the horse". Other unidentified factors may also be driving AT implementation. The connection between laws, standards/competencies, and implementation, and examination of 
states' decision-making concerning AT implementation, are areas that deserve further study. Critical issues to be examined include how AT decisions are made and how these decisions impact outcomes for students with disabilities.

This research identified other interesting issues to be explored in future research. First, without AT standards or competencies, it is unclear what guides consistency of AT implementation across the 51 states. Standards are intended to ensure the delivery of at least a minimal level of competence; without AT standards for teachers, the state and national educational systems may not be providing the experiences that teachers need in order to effectively and consistently address the AT needs of all students with disabilities.

Secondly, the great variation found in states' AT implementation activities provides initial evidence of an inconsistency of AT activities and services in educational systems across the country. While lack of variation cannot assure consistency of implementation, the wide variation found here should concern both special educators and general educators. These educators share responsibility for comprehensive, high-quality education to all students with disabilities through the IEP process, including required consideration of AT to support equal access to the general curriculum. Discovery of consistent elements of AT implementation that relate to academic success for students with disabilities would be extremely valuable to the field.

A third interesting issue to be explored relates to the role and effectiveness of professional organizations and networks that exist to support teachers' growth and development in their fields. AT is represented by an active professional organization, 
the Technology and Media Division (TAM) of CEC, which has recommended AT standards and competencies for special education technology specialists since 2000. It is unclear why, after almost ten years, most states have not embraced or adopted these or any other AT standards or competencies into the PD requirements for special educators or technology specialists.

The next issue is related to the connection between AT standards/competencies and implementation activities. It is unclear if the range and creativity of AT implementation would be limited or facilitated by integrating AT standards or competencies into state educational systems. This study found that while states have developed a wide range of AT implementation activities, the great majority of these take place in states without established AT standards or competencies. Studies that would identify the driving forces behind current AT implementation and the differences in the nature and especially the impact of these activities between states with and without AT standards or competencies would be useful.

Finally, this examination of AT standards and competencies and their relationship to EBP and related AT implementation did not address the same issues for general educational technology (ET). The connection between the ET standards established by ISTE, ET implementation, and student performance could offer insights for the field of AT. These studies could be used to help the field of AT frame its own standards and competencies, or to develop standards and competencies that can be infused within existing technology standards to make them more universally accessible. Such data could inform the fields of AT and ET as efforts driven by NCLB and IDEA continue to moving forward to effectively support all students in the 
general education environment. Research that will identify the best ways to connect the AT and ET systems is needed in order to achieve equity of access to education for all students, including students with disabilities.

Regression Analyses

This study identified and analyzed the types of AT standards or competencies in K-12 education systems across the US, the level of rigor in the evidence that these standards or competencies were based on, and the degree of AT implementation supported through state departments of education. Regression analyses were conducted to determine the relationship between these variables and national reading and math performance of students with disabilities. These findings were inconclusive because the pool of respondents was too few to allow for valid analyses, in spite of $100 \%$ response. The analyses were not significant, but Type II errors must be considered. This analysis should be replicated when more states have standards or competencies based on a range of evidence. In the present study, the results can be guardedly considered only for the AT implementation predictor variable, which was also not significant. The lack of a relationship between AT implementation activities and student outcomes is disheartening as these activities are intended to help students to function more effectively in their school environments, and presumably improve their academic performance. Of course, if these implementation activities are not grounded in research evidence (and it is unlikely that they are since there is so little evidence available, as documented in this literature review), it is difficult to assume that they are effective in producing change in the classroom performance. 
Of course, other, less pessimistic, explanations deserve consideration. It is possible that national performance data were too gross an outcome measure to determine the relationship of student performance with the predictor variables. Also, it may be the case that numerical performance measures do not adequately capture the academic performance of students with disabilities (due to issues of accessibility, grade performance level differences, response formats, etc.), and that more authentic methods for assessing academic performance (i.e. portfolios, student demonstrations, etc.) would yield different results. The AT process of feature matching, which individualizes the connection between AT, desired functions, and the individual, could also play a role in AT's impact on students' academic performance. These alternate explanations deserve further study.

If, however, there is truly no relationship between AT standards or competencies, AT evidence, AT implementation, and the academic performance of students with disabilities, it would be problematic. It would contradict conventional wisdom that AT helps students perform better academically. Indeed, a large body of literature documents students' increased opportunities to participate in classroom and school activities through AT in articles on technology and AT knowledge, as well as teacher's knowledge and skills in AT (Table 5). However, it is primarily case study research that links use of AT directly with student performance. Individual case study research is not held as particularly rigorous evidence, as it is hard to generalize. Further study of the relationship between AT variables and student performance is critical. Without documentation of an evidence-based relationship between these 
variables and some measure of student outcome, continued funding of AT would and should be ultimately questioned.

\section{Limitations of Study}

Every research study contains certain limitations. Identified limitations of this study include the following:

1) Discrepancy between data years for performance data and survey data. While the most recent available data on national academic performance of students with disabilities was used, that data had been collected during the 2006 academic year and was reported by the U.S. Department of Education in 2007. Data gathered in 2007 was not available to this researcher at the time of data gathering. The difference in data years could have affected study results. It is possible that the impact of AT implementation and standards could demonstrate different results on student performance over the one-to-two year discrepancy period. To determine this, further analyses would need to be performed using more recent national performance scores.

\section{2) Nature of performance data selected for use.}

This study attempted to determine if AT standards and competencies, AT implementation, and level of evidence rigor had any relationship to the academic performance of students with disabilities. As a national study, the best available academic performance scores were those from the states' state-wide assessments, as reported by the U.S. Department of Education. These scores contained disaggregated performance scores for students with disabilities who received special education in their states. The correlation analyses did not reveal any significant relationships 
between the predictor and criterion variables. It is possible that use of the national summative scores for states was simply too gross a measure to reveal any relationships between the AT standards and competencies of a state, the level of evidence these standards and competencies were based on, the degree of implementation of AT information and professional development by states, and the academic performance of students with disabilities on state-wide assessments. To look further at these possible relationships, some form of research that looks at student performance in a more disaggregated manner (such as school-based assessments, IEP assessments, etc.) could offer different results. The design of such a study would be complex, however it could add significantly to research in the AT field if it was able to extract clearer relationships with the predictor variables used in this study.

\section{3) Diverse needs of students with differing disabilities}

This study used performance scores for students with disabilities that were summary scores, regardless of the nature of the individual students' specific disabilities or specific use of AT. As identified in the literature, AT has a wide variety of applications, dependent upon the functions that each student needs support for in order to participate in the classroom and in general curriculum. The functions that need support relate to the area of disability need, i.e., communication, mobility, learning, etc. The relationship of AT standards and competencies and AT implementation to student performance could vary according to differing disabilities and functional needs. Future research that explored this study's predictor variables in relation to the academic performance of students of specific disability groups could yield valuable results to the fields of AT and education. 


\section{4) Limited available state AT standards or competencies}

Perhaps the greatest limitation of this study was the fact that very few states actually had AT standards or competencies that had been approved by their state departments of education and were being used to guide states' AT implementation practices. Of all of the 51 states (50 states plus Washington D.C.), only nine states reported having state-approved AT standards or competencies for their teachers in either independent or integrated forms. Only six of the nine states reported having evidence that was used to support their AT standards or competencies. Due to such low incidences of occurrence, it was very difficult to identify specific correlations or relationships between the study variables. It is unclear if more states will move forward to establish AT standards or competencies for teachers in the future, however without more data it is difficult to determine clear or valid relationships between the study variables. 


\section{CHAPTER 5}

\section{Conclusions and Recommendations}

Assistive technology (AT) allows general technology to be accessible to persons with disabilities. This study examined how three AT variables related to two areas of academic performance for students with disabilities. Descriptive and regression analyses of findings point to several primary conclusions and recommendations for further research.

Descriptively, this study of all 50 states plus Washington D.C. found that very few states have approved AT standards or competencies for teachers K-12. Even fewer have evidence of scientifically-based research or any other sources used in identifying or developing state AT standards or competencies. Considering the ten years that AT has been required to be considered in the development of students' IEPs, it is disappointing that most states lack AT standards/competencies for teachers who are required to make AT decisions for their students. In contrast, most states have adopted the National Educational Technology Standards (NETS) developed and published by ISTE for both students and teachers. Most recently revised in 2008 and relevant for all teachers in all content areas, the NETS include several performance indicators for teachers that reference "all students" and "equitable access". What remains unknown, however, is how well these indicators will promote development of adequate teacher knowledge and skills to address the widely diverse AT needs of students with disabilities. A recommended follow-up to this study is research to look at how NETS are being used by teachers to support students with disabilities, how effective they are, and if supplements or adjustments are needed to meet the needs of 
students with disabilities. Results of such research could identify recommended modifications or additions to NETS that will reflect the needs of all students. It could also determine if separate AT standards or competencies for teachers would be more beneficial for students.

Regarding AT implementation, most notable was the apparent relationship between the presence of AT standards/competencies for teachers and some level of state-required PD for teachers. While most states had no required PD in AT for their teachers, they also had no established AT standards or competencies. Much AT implementation, however, appears facilitated by laws, rather than standards or competencies. It also appears that when standards or competencies are in place, however, changes in teacher PD take place. Determining (1) if AT standards and competencies need to be required by law in order to become implemented, (2) if they should be infused within general educational technology standards in order to be implemented, and (3) if they need to exist at all in order for students with disabilities to be academically successful, are research areas that deserve greater study.

The multiple regression analyses intended to identify the connection between AT variables at the state level to student performance outcomes appear to be premature, as many states did not have sufficient AT variables in place that could be adequately measured. It is not too early, however, for the field to aggressively pursue this line of inquiry. There is an assumption that AT has a positive impact on student performance, an assumption supported by many descriptive studies in the literature (Higgins \& Raskind, 2005; MacArthur \& Cavalier, 2004; Lee \& Vail, 2005; Stoner, Esterbrooks, \& Laughton, 2005; Tumlin \& Heller, 2004), as well as program and 
professional reports (American Speech-Language-Hearing Association, 1997; Council for Exceptional Children, 2003; Minnesota Department of Education, 2005). The identification of studies in educational technology that have addressed these and other variables and their correlation with student performance should be pursued, as well as new research to look at the impact of different AT variables on student performance.

Study interviews revealed many efforts under way to either expand the number of states establishing specific AT standards or competencies for teachers, or move toward a UDL-influenced implementation model that seeks to address AT within general educational technology planning. An integrated standards model could be effective in developing teachers knowledge and skills in AT, or it may be that unique factors of AT require independent standards and competencies. No definitive conclusions were reached, either, about benefits to states using existing professional AT standards as guidelines, as opposed to states that developed their own sets of AT standards or competencies for teachers. The study, however, does raise concerns that adoption of standards or competencies developed for a specific profession could limit states' AT implementation to support all students and professionals appropriately. A follow-up study in perhaps 5 to 10 years, documenting the presence of AT standards and competencies and comparing that to this study's results, would be valuable to the field. Findings may indicate continued growth in this area, or a field moving away from following separate AT standards or competencies for teachers; determining why, would be an important addition to research of the field.

Finally, further discussion of EBP in the context of the field of AT is important. As presented in the literature review, the EBP model that was developed 
initially in the field of medicine, requires consideration of both scientific and clinical evidence to determine best practice. As EBP has moved into the field of education, significant emphasis has been placed on showing proof (evidence) of effective practice through rigorous scientific experimental methods, commonly referred to as the "gold standard" of evidence in education. Much less emphasis is found in the literature on the importance of field-based evidence in the EBP model. It appears that much of the field has taken the approach that unless it is "gold standard" evidence it is not valuable. Since there is no "gold standard" evidence available, other types of evidence are ignored. This is misinterpretation of the Davies EBP hierarchy.

Clearly, the present study is a beginning. The multiple factors that potentially impact AT and its effectiveness to support students with disabilities to be academically successful may be daunting, but it is the hope of this researcher that this study can serve as a foundation for many future studies, and that through such research the field of AT will quickly grow in its position to successfully demonstrate its value through EBP. 


\title{
APPENDIX A
}

\author{
AT Survey Form \\ United States Assistive Technology Standards \& Competencies \\ Telephone Data Collection Form \\ E.M. Dalton, Investigator \\ U.R.I./R.I. College Joint PhD in Education Program \\ 2008
}

State:

Contact name:

Contact title/position:

Department of Education office:

Contact phone \#:

Contact email:

Date completed:

This research seeks to identify state policies and materials effecting assistive technology (AT) use at the K-12 level. Please respond to all questions to the best of your ability.

What term does your state officially use? __ AT standards __AT competencies __Both _ _Neither

\section{AT Standards}

1a. Do state-approved AT standards (K-12) exist for your state?

If yes, do they include:

a. content standards (for students)?

b. performance standards (for students)?

c. curriculum standards (for teachers)?

d. delivery standards (for teachers)?

(If no, skip to Item 2a.)

$\mathrm{Y}_{-}$
$\mathrm{Y}-\mathrm{N}_{-}$
$\mathrm{N}-\mathrm{N}_{-}$
$\mathrm{Y} \_$
$\mathrm{N}-\mathrm{N}_{-}$

1b. Does your state use AT standards developed by another professional organization or group?

If yes, please indicate which group:

$\mathrm{Y}$

National Assoc. of State Directors of Special Education (NASDSE)

Council for Exceptional Children (CEC)

American Occupational Therapy Association (AOTA)

American Speech and Hearing Association (ASHA)

Other (provide group name)

1c. Which statement best applies for your state?

__ AT standards exist independently (not within other sets of standards, e.g. math, English, etc.)

AT standards are integrated within other sets of standards some AT standards exist independently, some are integrated

1d. For each type of AT standard (noted in 1a), is it independent or integrated into other standards?

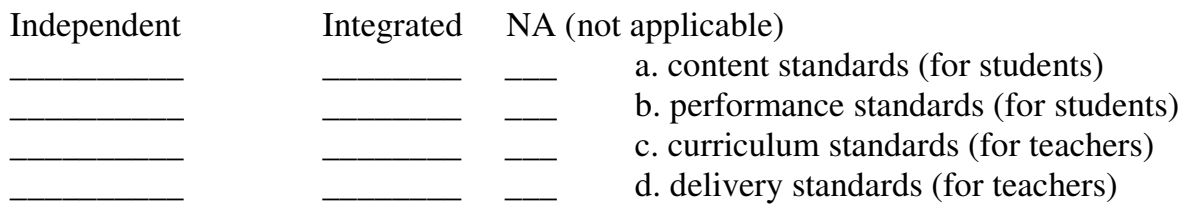

1e. How can these standards be accessed by educators and the public? 
_ website _ publication (e.g. brochure, manual, etc.) _ other - explain:

1f. At the state level, does information exist that explains how your AT standards were developed?

If yes, what sort of information? _ web-based

_ printed

__ other - explain:

How can this material be obtained?

1g. At the state level, does documentation of specific evidence exist that was used to develop AT standards?

If yes, what is this documentation?

_ published research

$\mathrm{Y}_{-} \mathrm{N}_{2}$

_ professional articles

_ professional reports

_ other - explain:

Please provide title and location (web link, etc.) of evidence:

\section{AT Competencies}

2a. Do state-approved AT competencies (K-12) exist for your state?

If yes, do they include:

(If no, skip to Item 3a.)

b. performance competencies (for students)? $\mathrm{Y}$

c. curriculum competencies (for teachers)? $\mathrm{Y}_{-} \mathrm{N}_{-}$

d. delivery competencies (for teachers)? $\mathrm{Y}_{-} \mathrm{N}_{-}$

2b. Does your state use AT competencies developed by another professional organization or group?

$\mathrm{Y}$

If yes, please indicate which group:

National Assoc. of State Directors of Special Education (NASDSE)

Council for Exceptional Children (CEC)

American Occupational Therapy Association (AOTA)

American Speech and Hearing Association (ASHA)

Other (provide group name)

2c. Which statement best applies for your state?

AT competencies exist independently (not within other sets of competencies, e.g. science,

etc.)

AT competencies are integrated within other competencies

some AT competencies exist independently, some are integrated

2d. For each type of AT competency (notes in 2a), is it independent or integrated into other competencies?

\begin{tabular}{|c|c|c|}
\hline Independent & Integrated & NA (not applicable) \\
\hline & & a. content competencies (for students) \\
\hline & & b. performance competencies (for students \\
\hline & & $\begin{array}{l}\text { c. curriculum competencies (for teachers) } \\
\text { d. delivery competencies (for teachers) }\end{array}$ \\
\hline
\end{tabular}

2e. How can these competencies be accessed by educators and the public? 
_ website _ publication (e.g. brochure, manual, etc.) _ other - explain:

2f. At the state level, does information exist that explains how your AT competencies were developed?

If yes, what sort of information?

web-based material

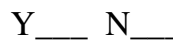

_ printed material

_ other - explain:

How can this material be obtained?

$2 \mathrm{~g}$. At the state level, does documentation of specific evidence exist that was used to develop AT competencies?

If yes, what is this documentation? _ published research

_ professional articles

_ professional reports

__ other - explain:

Please provide title and location (web link, etc.) of evidence:

\section{AT Implementation}

3a. Does the state provide instructions to educators for implementing AT (e.g. brochures, manuals, web-based, etc.)? Y $\mathrm{N}$

If yes, in what areas?

a. for general use in the education system? $\quad \mathrm{Y}_{-} \mathrm{N}_{-}$

b. for use specifically in classrooms? $\quad \mathrm{Y}-\mathrm{N}$

c. for use specifically in state-wide testing? $\mathrm{Y}_{-} \mathrm{N}_{2}$

d. for use specifically in IEP development/implementation? Y $\mathrm{N}$

3b. Is AT included in preservice or inservice professional development programs in your state?

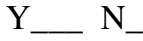

If yes, in what areas?

a. state offers recommendations for teacher prof. dev. in AT?

b. state has requirements for teacher prof. dev. in AT?

c. state has established AT endorsement for teachers?

d. state has established AT certification for teachers?

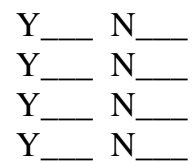

3c. At the state dept. of education, have you taken any other actions to implement AT? Y_ If yes, please explain:

\section{Comments}

4. Is there any other information that you would like to provide about your state re: AT standards, AT competencies, or AT implementation? 
Thank you so much for your time and for your responses. If you are interested, I am happy to send you an executive summary of the survey results.

Please select: __ Yes, forward the results to my email address. __ _ No, thanks.

\section{Note:}

The intent of this study is to collect data via the telephone and you will be contacted by the researcher for this purpose, however if you are unable to speak with the researcher by phone, please fax this completed data form to: 401-456-8150 (Paul V. Sherlock Center @ RI College, Attention: Elizabeth Dalton, voice \# 401-456-4736). 
Letter of Introduction

\section{LETTERHEAD}

To: (Name), (State name) Department of Education, Assistive Technology (AT) Contact From: Elizabeth Dalton, Principal Investigator, AT Standards in Education Study Date: (December 2007/January 2008)

Re: Gathering national data on AT standards, evidence, and implementation

This letter provides information about my dissertation study on AT standards in the US education system. I am seeking to identify what AT standards and/or competencies each state has established for students and teachers, what evidence these standards and/or competencies were based on, and what level of AT implementation exists in each state, according to information and professional development indicators.

As you have been identified as the primary AT contact for your state department of education, I hope that you will be able to assist me in gathering this information on AT standards, evidence, and implementation across the country. You may be interested in more information on these concepts, and I have included a summary on the enclosure.

Attached please find the form that I will be using for data collection. I would like to call and speak with you to collect this information, however I am providing you with the data form prior to the telephone session so that you will have time to identify and prepare any relevant information. Telephone sessions are expected to take 10-15 minutes, and are targeted to take place during the month of January, beginning after January $3^{\text {rd }}$. My goal is to gather accurate and complete data from every state (and the District of Columbia) on AT standards \& implementation in elementary \& secondary education, and to compare this data with national student performance scores to see if these AT factors show any predictability for the academic performance of students with disabilities. To do this, I sincerely depend upon your information.

The executive summary of this study, following completion, will be shared with each state, upon request. Please indicate your preference for this summary during the telephone session.

Research in AT is an important part of the growing body of evidence in the field of education. I appreciate your interest in this study, and look forward to speaking with you by telephone in the near future. Please contact me at (401) 456-4736(office), (401)-529-8733(cell), or edalton@ ric.edu with any questions concerning this study. 
Concepts \& definitions relevant to this study:

\section{A. Types of Standards or Competencies}

According to Sweeney (1999), there are four specific types of educational standards:

1. Content - what students should know and how well they should be able to use the knowledge;

2. Performance - how well students must know and do specific content assessment tasks;

3. Curriculum - what teachers must teach in order for students to know what they should know;

4. Delivery - what educators must know and do if students are to perform at a desired level on specific content assessment tasks.

\section{B. Types and Levels of Evidence}

Based upon the work of Davies (1999), who incorporated the original work of Sackett, et al. (1996) to develop a continuum of rigor (or power) for evidence in education, six different levels of evidence (ranging from most to least rigorous) will be applied in this study:

1) Randomized clinical trials (RCT)

2) Experimental \& quasi-experimental studies

3) Survey \& correlational research (simple \& multiple correlation, regression analysis, analysis of variance)

4) Expert opinion (defining processes, meanings, categories \& practices by field professionals)

5) Ethnographies/case studies/observations (analysis of consequences of activities by interaction/conversation/discourse)

6) Ethics studies (universal vs. selective action, informed choices, social inequities, social justice, resource allocation, and values).

All available information regarding evidence used to develop and establish AT standards and/or competencies is sought for this study.

\section{Indicators of AT Implementation}

For the purposes of this study, indicators of AT implementation will include the types and extent of instructions provided by each state on AT use in education (concerning general system, classroomspecific, state-wide testing, or IEP applications) and the types and extent of AT integration into professional development (recommendations, requirements, endorsement, or certification).

\section{References:}

Davies, P. (1999). What is evidence-based education? British Journal of Educational Studies, 47, 108121.

Sackett, D. L., Rosenberg, W. M. C., Gray, J. A. M., Haynes, R. B., \& Richardson, W. S. (1996). Evidence based medicine: What it is and what it isn't. British Medical Journal, 312, 71-72.

Sweeny, B. (1999). Content standards: Gate or bridge.[Electronic version]. Kappa Delta Pi Record, 35(2), 1-5. Retrieved March 4, 2007 from hwwilsonweb database. 


\section{APPENDIX B}

\section{Data Classification Forms}

Form 1

Identification of States' AT Standards \& Competencies Information from State Websites

State:

Contact:

Date completed:

Contact title:

Contact phone \#:

Contact email:

\begin{tabular}{|c|c|c|c|}
\hline AT Factors & Response/Type & $\begin{array}{l}\text { Web } \\
\text { address \& } \\
\text { date of } \\
\text { posting }\end{array}$ & Comments/Description \\
\hline $\begin{array}{l}\text { 1a. State approved AT } \\
\text { standards exist } \\
(\mathrm{K}-12)\end{array}$ & $\begin{array}{l}\text { Y N } \\
\text { Con Per Curr Del }\end{array}$ & & \\
\hline $\begin{array}{l}\text { 1b. How standards exist at } \\
\text { state level }\end{array}$ & $\begin{array}{lcc}\text { Independently } & \mathrm{Y} & \mathrm{N} \\
\text { Integrated } & \mathrm{Y} & \mathrm{N} \\
\text { Both ways } & \mathrm{Y} & \mathrm{N}\end{array}$ & & \\
\hline $\begin{array}{l}\text { 1c. Which of each type? } \\
\text { Content standards? } \\
\text { Performance standards? } \\
\text { Curriculum standards? } \\
\text { Delivery standards? }\end{array}$ & \begin{tabular}{cccc}
\multicolumn{3}{c}{ Indep. } & \multicolumn{2}{c}{ Integr. } \\
Y & $\mathrm{N}$ & $\mathrm{Y}$ & $\mathrm{N}$ \\
$\mathrm{Y}$ & $\mathrm{N}$ & $\mathrm{Y}$ & $\mathrm{N}$ \\
$\mathrm{Y}$ & $\mathrm{N}$ & $\mathrm{Y}$ & $\mathrm{N}$ \\
$\mathrm{Y}$ & $\mathrm{N}$ & $\mathrm{Y}$ & $\mathrm{N}$
\end{tabular} & & \\
\hline $\begin{array}{l}\text { 2a. State approved AT } \\
\text { competencies exist } \\
(\mathrm{K}-12)\end{array}$ & $\begin{array}{l}\text { Y } \quad \mathrm{N} \\
\text { Con Per Curr Del }\end{array}$ & & \\
\hline $\begin{array}{l}\text { 2b. How competencies exist at } \\
\text { state level }\end{array}$ & $\begin{array}{lcc}\text { Independently } & \mathrm{Y} & \mathrm{N} \\
\text { Integrated } & \mathrm{Y} & \mathrm{N} \\
\text { Both ways } & \mathrm{Y} & \mathrm{N} \\
\end{array}$ & & \\
\hline $\begin{array}{l}\text { 2c. Which of each type? } \\
\text { Content competencies? } \\
\text { Performance competencies? } \\
\text { Curriculum competencies? } \\
\text { Delivery competencies? }\end{array}$ & \begin{tabular}{llll}
\multicolumn{2}{c}{ Indep. } & \multicolumn{2}{c}{ Integr. } \\
Y & $\mathrm{N}$ & $\mathrm{Y}$ & $\mathrm{N}$ \\
$\mathrm{Y}$ & $\mathrm{N}$ & $\mathrm{Y}$ & $\mathrm{N}$ \\
$\mathrm{Y}$ & $\mathrm{N}$ & $\mathrm{Y}$ & $\mathrm{N}$ \\
$\mathrm{Y}$ & $\mathrm{N}$ & $\mathrm{Y}$ & $\mathrm{N}$
\end{tabular} & & \\
\hline $\begin{array}{l}\text { 3. State AT use guidelines } \\
\text { exist? }\end{array}$ & $\mathrm{Y} \quad \mathrm{N}$ & & \\
\hline $\begin{array}{l}\text { Guidelines for AT use } \\
\text { (general) }\end{array}$ & $\mathrm{Y} \quad \mathrm{N}$ & & \\
\hline $\begin{array}{l}\text { Guidelines for AT use } \\
\text { (classroom) }\end{array}$ & $\mathrm{Y} \quad \mathrm{N}$ & & \\
\hline $\begin{array}{l}\text { Guidelines for AT use (state } \\
\text { testing) }\end{array}$ & Y N & & \\
\hline $\begin{array}{l}\text { Guidelines for AT use (IEP } \\
\text { dev/implem) }\end{array}$ & $\mathrm{Y} \quad \mathrm{N}$ & & \\
\hline
\end{tabular}




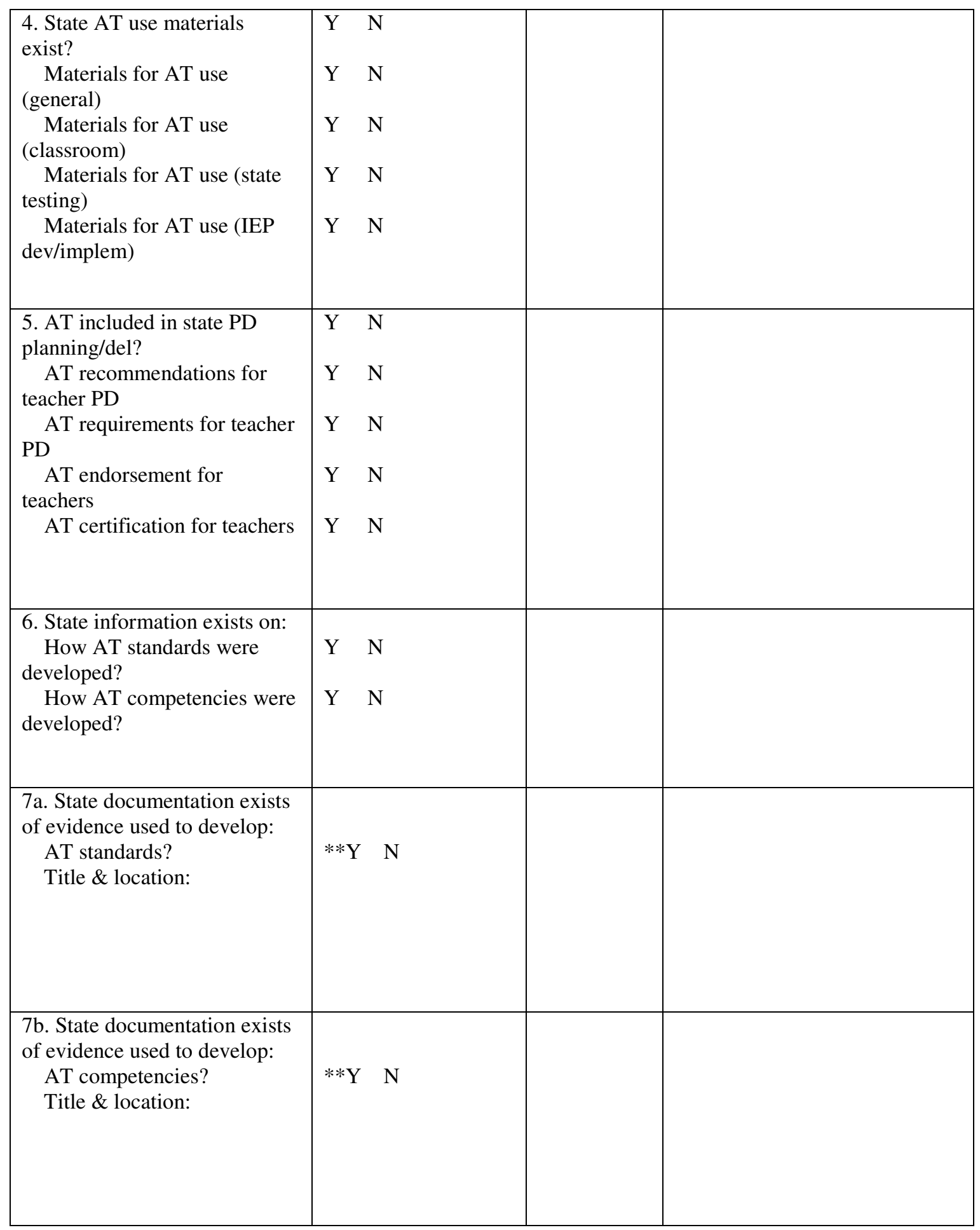

** If Y, code evidence as per Davies

8. Investigator comments: 
Form 2

Classification of Evidence for AT Standards/Teacher Competencies (Davies, 1999)

State:

For: AT standards _ or Teacher competencies___ Comments

\begin{tabular}{|c|c|c|}
\hline $\begin{array}{l}1 \\
2 \\
\mathrm{~N}\end{array}$ & 1) Randomized clinical trials (RCT) & \\
\hline $\begin{array}{l}1 \\
2 \\
\mathrm{~N}\end{array}$ & 2) Experimental \& quasi-experimental studies & \\
\hline $\begin{array}{l}1 \\
2 \\
\mathrm{~N}\end{array}$ & $\begin{array}{l}\text { 3) Survey \& correlational research (simple } \& \\
\text { multiple correlation, regression analysis, } \\
\text { analysis of variance) }\end{array}$ & \\
\hline $\begin{array}{l}1 \\
2 \\
\mathrm{~N}\end{array}$ & $\begin{array}{l}\text { 4) Expert opinion (defining of } \\
\text { processes, meanings, categories \& } \\
\text { practices by field professionals) }\end{array}$ & \\
\hline $\begin{array}{l}1 \\
2 \\
\mathrm{~N}\end{array}$ & $\begin{array}{l}\text { 5) Ethnographies/case studies/observations } \\
\text { (analysis of consequences of activities by } \\
\text { interaction/conversation/discourse) }\end{array}$ & \\
\hline $\begin{array}{l}1 \\
2 \\
\mathrm{~N}\end{array}$ & $\begin{array}{l}\text { 6) Ethics studies (universal vs. selective action, } \\
\text { informed choices, social inequities, social } \\
\text { justice, resource allocation, and values) }\end{array}$ & \\
\hline
\end{tabular}

Key:

$1=$ meets criteria completely with research documentation

$2=$ minimally meets criteria (evidence stated; little to no research documentation)

$\mathrm{N}=$ no evidence identified 


\section{APPENDIX C}

\section{AT State Department of Education Contacts}

\begin{tabular}{|c|c|c|}
\hline$\underline{\text { State }}$ & $\underline{\text { Title }}$ & Received \\
\hline$\overline{\text { Alabama }}$ & 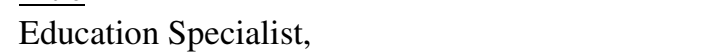 & $2 / 4 / 2008$ \\
\hline Alaska & Executive Director & $2 / 26 / 2008$ \\
\hline Arizona & Director, Special Projects & $2 / 7 / 2008$ \\
\hline Arkansas & Director, Technology \& Curriculum Access & $3 / 4 / 2008$ \\
\hline California & Special Education Consultant & $2 / 28 / 2008$ \\
\hline Colorado & Director, Assistive Technology Partners & $3 / 6 / 2008$ \\
\hline Connecticut & Educational Consultant & $2 / 13 / 2008$ \\
\hline Delaware & Educational Consultant/Curriculum Access & $2 / 28 / 2008$ \\
\hline District of Columbia & Asst. Superintendent for Special Education & $3 / 4 / 2008$ \\
\hline Florida & Program Director & $2 / 13 / 2008$ \\
\hline Georgia & Program Manager, Georgia Project for AT & $2 / 25 / 2008$ \\
\hline Hawaii & State Office Resource Teacher for AT & $1 / 25 / 2008$ \\
\hline Idaho & Training Coordinator & $2 / 25 / 2008$ \\
\hline Illinois & Principal Education Consultant & $1 / 18 / 2008$ \\
\hline Indiana & Assistant Director & $3 / 6 / 2008$ \\
\hline Iowa & AT Specialist & $3 / 4 / 2008$ \\
\hline Kansas & Education Program Consultant & $2 / 25 / 2008$ \\
\hline Kentucky & Exceptional Children AT Consultant & $2 / 4 / 2008$ \\
\hline Louisiana & $\begin{array}{l}\text { Education Consult and \& AT Specialist } \\
\text { Policy Director \& Team Leader/ Intermediate }\end{array}$ & $3 / 6 / 2008$ \\
\hline Maine & Education & $3 / 4 / 2008$ \\
\hline Maryland & Statewide Blind, VI, \& Low Incidence Specialist & $3 / 6 / 2008$ \\
\hline Massachusetts & $\begin{array}{l}\text { Instructional Technology Specialist } \\
\text { Director, Michigan Integrated Technology }\end{array}$ & $2 / 6 / 2008$ \\
\hline Michigan & Supports & $2 / 8 / 2008$ \\
\hline Minnesota & AT \& UDL Specialist & $1 / 16 / 2008$ \\
\hline Mississippi & Division Director & $3 / 6 / 2008$ \\
\hline Missouri & Director, Missouri Assistive Technology & $2 / 14 / 2008$ \\
\hline Montana & $\begin{array}{l}\text { Director, Special Education } \\
\text { Educational Assistive Technology Program }\end{array}$ & $3 / 5 / 2008$ \\
\hline Nebraska & Coordinator & $3 / 3 / 2008$ \\
\hline Nevada & Assistant Director, Special Education & $2 / 8 / 2008$ \\
\hline New Hampshire & Special Education Consultant & $3 / 4 / 2008$ \\
\hline New Jersey & Program Development Specialist I & $2 / 14 / 2008$ \\
\hline New Mexico & Deputy Director & $3 / 11 / 2008$ \\
\hline New York & Project Coordinator & $2 / 20 / 2008$ \\
\hline North Carolina & Consultant for VI \& AT & $1 / 25 / 2008$ \\
\hline North Dakota & Regional Coordinator, AT \& NIMAS & $2 / 20 / 2008$ \\
\hline Ohio & Consultant & $2 / 25 / 2008$ \\
\hline Oklahoma & Preschool Coordinator & $2 / 29 / 2008$ \\
\hline Oregon & Coordinator, Oregon Tech Access Program & $3 / 6 / 2008$ \\
\hline Pennsylvania & Program Manager, PATTAN & $2 / 14 / 2008$ \\
\hline Rhode Island & AT Coordinator & $12 / 19 / 2007$ \\
\hline South Carolina & Assistive Technology Regional Specialist & $3 / 4 / 2008$ \\
\hline South Dakota & Educational Program Representative & $2 / 8 / 2008$ \\
\hline
\end{tabular}


Tennessee

Texas

Utah

Vermont

Virginia

Washington

West Virginia

Wisconsin

Wyoming
Consultant for AT

Senior Education Specialist

Technical Support Specialist

Special Education Consultant

Education Specialist in AT

Interagency Program Supervisor

Program Coordinator

Educational Consultant, SLP \& AT

Education Program Manager
$3 / 3 / 2008$

$2 / 20 / 2008$

$1 / 22 / 2008$

$2 / 25 / 2008$

$1 / 25 / 2008$

$3 / 3 / 2008$

$1 / 25 / 2008$

$2 / 22 / 2008$

$2 / 4 / 2008$ 


\section{APPENDIX D}

\section{Glossary of Terms}

Accessible Instructional Materials Consortium (AIM): A national consortium of states working to achieve appropriate implementation of the National Instructional Media Accessibility Standard (NIMAS).

Assistive technology (AT): Technology to support the functional needs of persons with disabilities. AT includes low tech and high tech devices for all ages and disability types. Federal definitions of AT include both AT devices and AT services.

Assistive technology standards: A standard is a principle mutually agreed upon by people engaged in a professional practice that will enhance the quality of that professional practice. AT standards, as related to education, are statements of what students and teachers should know and be able to do with AT in schools to support learning and other functions.

Evidence-based practice (EBP): A practice that is based upon measurable scientific evidence, as well as clinical information. In EBP, rigor or strength of evidence varies along a continuum from least rigorous (observations or observational studies) to most rigorous (random clinical trials).

Indicators of AT implementation: Tangible products or procedures that have resulted from implementing AT policies at the state level. Examples include, but are not limited to, posted standards, guidelines, materials, and policy statements by the states.

National Instructional Media Accessibility Standard (NIMAS): Federal legislation requiring all states to secure accessible instructional materials for all students, in formats that are appropriate to individual learning styles and needs. Publishers must produce and supply educational materials in formats that are accessible for students with disabilities.

Special education students: Students, K-12, who have been assessed and identified as eligible to receive special education services based upon educational needs arising from an area or areas of disability. Special education students in the U.S. have individualized educational programs (IEP) to guide their special education services, including guidance for participation in state-wide assessments.

State Leaders in Assistive Technology in Education (SLATE): A national organization of K-12 educators and administrators who represent their states as leaders in assistive technology policy and practice.

State test performance: Annual test scores that indicate how public school students performed on required state performance assessments, specifically in reading and mathematics. 
Universal Design for Learning (UDL): Originally based upon the architectural concept of universally accessible design of physical environments for persons with varying needs and abilities, UDL transfers this concept to learning environments. UDL defines multiple means of representation, expression, and engagement in the classroom to accommodate the widest range of learner needs without separate modifications.

Universal Instructional Design (UID): Most frequently used in reference to higher education environments, UID is the expansion of teaching methodologies to allow students with disabilities and all students with diverse learning needs to have equal access to classroom teaching and learning. 


\section{BIBLIOGRAPHY}

Abell, M. M., Bauder, D. K., \& Simmons, T. J. (2005). Access to the general curriculum: A curriculum and instruction perspective for educators. Intervention in School and Clinic, 41(2), 82-86.

Albee, J. J. (2003). A study of preservice elementary teachers' technology skill preparedness and examples of how it can be increased. Journal of Technology and Teacher Education, 11(1), 53-71.

Aleman, S. R. (1991). Education of the Handicapped Act Amendments of 1990, P.L. 101-476: A summary. Washington, DC: Library of Congress. (ERIC Document Reproduction Service No. ED343318)

Alexander, N. A. (2002). Race, poverty, and the student curriculum: Implications for standards policy. American Educational Research Journal, 39(3), 675-693.

Alper, S., \& Raharinirina, S. (2006). Assistive technology for individuals with disabilities: A review and synthesis of the literature. Journal of Special Education Technology, 21(2), 47-64.

American Speech-Language-Hearing Association (1997). Maximizing the Provision of Appropriate Technology Services and Devices for Students in Schools [Relevant Paper]. Retrieved June 19, 2007, from http://www.asha.org/docs/html/RP1997$\underline{00210 . h t m l}$

Angeli, C. (2005). Transforming a teacher education method course through technology: Effects on preservice teachers' technology competency. Computers and Education, 45(4), 383-398.

Archambault, F. X., Kurlikowich, J. M., Brown, S. W., \& Rezendes, G. J. (2002). Developing performance assessments to measure teacher competency in the use of educational technology [Abstract]. (ERIC Document Reproduction Service No. ED465759)

Association for the Advancement of Rehabilitation Research (RESNA). (1998a). Creating systems change through policies, practices, laws, regulations, procedures, and organizational structures. Tech Act Projects accomplishments series. Arlington, VA: National Institute on Disability and Rehabilitation Technology. (ERIC Document Reproduction Service No. ED418550).

Association for the Advancement of Rehabilitation Research (RESNA). (1998b). Improving access, provision, and funding for assistive technology devices and services. Tech Act Projects accomplishments series. Arlington, VA: National 
Institute on Disability and Rehabilitation Research. (ERIC Document Reproduction Service No. ED418551)

Association for the Advancement of Rehabilitation Research (RESNA). (2007). Technology-related assistance for individuals with disabilities act of 1988 as amended in 1994. (Public laws 100-407 and 103-218). Retrieved August 5, 2007, from http://www.resna.org/taproject/library/laws/techact94.htm

Awbrey, M. (1995). Questions and answers: Administrator views of the uses and value of the standards. Social Studies Review, 35(1), 30-33.

Baker, E. L., \& Linn, R. L. (1997). Emerging educational standards of performance in the united States: CSE Technical Report 437. Los Angeles, CA: UCLA National Center for Research on Evaluation, Standards, and Student Testing (CRESST).

Baker, E. L., Linn, R. L., \& Koretz, D. (2002). Standards for educational accountability systems: Policy brief 5. Los Angeles, CA: UCLA National Center for Research on Evaluation, Standards, and Student Testing (CRESST).

Barron, A. E., Kemker, K., Harmes, C., \& Kalaydjian, F. (2003). Large-scale research study on technology in K-12 schools: Technology integration as it relates to the National Technology Standards. Journal of Research on Technology in Education, 35(4), 489-507.

Bausch, M. E., \& Hasselbring, T. S. (2004). Assistive technology: Are the necessary skills and knowledge being developed at the preservice and inservice levels? Teacher Education and Special Education, 27(2), 97-104.

Baylor, A. L. (2002). Expanding preservice teachers metacognitive awareness of instructional planning through pedagogical agents. Educational Technology Research and Development, 50(2), 5-22.

Baylor, A. L., \& Ritchie, D. (2002). What factors facilitate teacher skill, teacher morale, and perceived student learning in technology-using classrooms? Computers and Education, 39(4), 395-414.

Beach, R. H., \& Lindahl, R. A. (2000). New standards for the preparation of school administrators: What conceptualization of educational planning do they portray? Planning and Changing, 31(1-2), 35-52.

Beasley, W., \& Wang, L. C. (2001). Implementing ISTE/NCATE technology standards in teacher preparation: One college's experience. Information Technology in Childhood Education Annual, 33-44.

Behrmann, M., \& Jerome, M. K. (2002). Assistive technology for students with mild disabilities: Update 2002. (ERIC Document Reproduction Service No. EDO-EC- 
02-01) Retrieved September 17, 2006 from

http://permanent.access.gpo.gov/websites/eric.ed.gov/ERIC_Digests/ed463595.ht

m

Beichner, R. J. (1993). Technology competencies for new teachers: Issues and suggestions. Journal of Computing in Teacher Education, 9(3), 17-20.

Bell, J. K. (2001). The impact of the 1997 reauthorization of the Individuals with Disabilities Education Act on assistive technology policies of state departments of education [Electronic version]. Doctoral dissertation, University of Kentucky. (ProQuest Pub. No. AAT30776590)

Bell, J. K., \& Blackhurst, A. E. (1996). Assistive technology policies of state departments of education: The baseline investigation. Lexington, KY: University of Kentucky, National Assistive Technology Research Institute.

Bennett, L. (2000). Technology standards for the preparation of teachers. International Journal of Social Education, 15(2), 1-11.

Bennett, L. (2005). Guidelines for using technology in the social studies classroom. Social Studies, 96(1), 38-44.

Berliner, D. C. (2002). Educational research: The hardest science of all. Educational Researcher, 31(8), 18-20.

Bielefeldt, T. (2001). Technology in teacher education. Journal of Computing in Teacher Education, 17(4), 4-15.

Biesta, G. (2007). Why "what works" won't work: Evidence-based practice and the democratic deficit in educational research. Educational Theory, 57(1), 1-32.

Bingman, B., Joyner, S., \& Smith, C. (2003). The role of professional development in promoting evidence-based practice. Paper presented at the Meeting of the Association of Adult Literacy Professional Developers and the National Center for the Study of Adult Learning and Literacy. Retrieved March 13, 2007, from www.aalpd.org/coabe2003aalpdsession.ppt

Bitter, G., Thomas, L., Knezek, D. G., Friske, J., Taylor, H., Wiebe, J., et al. (1997). National Educational Technology Standards (NETS): Developing new learning environments for today's classroom. NASSP Bulletin, 81(592), 52-58.

Blackhurst, A. E., \& Edyburn, D. L. (2000). A brief history of special education technology. Special Education Technology Practice, 2(1), 21-35. 
Boone, R. \& Higgins, K. (2007). The role of instructional design in assistive technology research and development. Reading Research Quarterly 42(1), 135139.

Bowser, G., \& Reed, P. (1995). Education TECH points for assistive technology planning. Journal of Special Education Technology, 12 (4), 325-328.

Brown, C. C., \& Cavalier, A. R. (1992). Voice recognition technology and persons with severe mental retardation and severe physical impairment: Learning, response differentiation, and affect. Journal of Special Education Technology, XI (4), 196-206.

Burton, T. M. (2004). Analysis of technology competence of K-12 teachers in a selected school district in Mississippi [Abstract]. Doctoral dissertation, University of Southern Mississippi. (ProQuest Pub. No. AAT 3147905)

Calculator, S. N. (1999). AAC outcomes for children and youths with severe disabilities: When seeing is believing. Augmentative and Alternative Communication, 15, 4-12.

California Department of Education. (2006). Competencies for assistive technology providers. Retrieved February 20, 2007, from http://www.cde.ca.gov.sp/se/sr/atstaff/asp

Campbell, J. R., Hombo, C. M., \& Mazzeo, J. (2000). NEAP 1999 trends in academic progress: Three decades of student performance (Statistical analysis No. NCES 2000469). Washington, DC: National Center for Educational Statistics. Retrieved May 21, 2007, from http://nces.ed.gov/pubsearch/ppubsinfo.asp?pubid=2000469

Campbell, D. M. (2000). Views of assistive technology. Unpublished doctoral dissertation, University of Massachusetts at Amherst.

Campbell, P. H., Milbourne, S., \& Dugan, L. M. (2006). A review of evidence on practices for teaching young children to use assistive technology devices. Topics in Early Childhood Special Education, 26(1), 3-14.

Cardillo, D. (2005). Helping teachers embrace standards.[Electronic version]. Learning and Leading with Technology, 33(2), 10-14.

Carey, D. M., \& Sale, P. (1994). Practical considerations in the use of technology to facilitate the inclusion of students with severe disabilities. Technology and Disability, 3 (2), 77-86.

Caverly, D. C., \& MacDonald, L. (2005). Techtalk: Wireless networking. Journal of Developmental Education, 28(3), 38-39. 
Center for Applied Special Technology. (2001). Universal design for learning. Retrieved January 25, 2008, from http://www.cast.org/udl

Chen, M. -C., Wu, T. -F., \& Chu, C. -N. (2004). Essential competencies of special educators in integrating assistive technology into the curriculum [Electronic version]. Lecture Notes in Computer Science, (3118), 117-177.

Chiero, R., Sherry, L., Bohlin, R., \& Harris, S. (2003). Increasing comfort, confidence, and competence in technology infusion with learning communities. TechTrends, $47(2), 34-38$.

Cochran-Smith, M. (2003). The unforgiving complexity of teaching: Avoiding simplicity in the age of accountability. Journal of Teacher Education, 54(1), 3-5.

Collier, A., Weinburgh, M. H., \& Rivera, M. (2004). Infusing technology skills into a teacher education program: Change in students' knowledge about and use of technology. Journal of Technology and Teacher Education, 12(3), 447-468.

Connecticut Department of Education. (2007). Assistive Technology Guidelines. Retrieved August 22, 2007, from http://www.birth23.org/Publications/assistivetech.pdf

Council of Chief State School Officers. (2001). Ensuring the educational rights of all children. The 2001 Council priority. Washington, DC: Author. (ERIC Document Reproduction Service No. ED464421)

Council for Exceptional Children. (2003). What every special educator must know: Ethics, standards, and guidelines for special educators ( $5^{\text {th }}$ ed.). Upper Saddle River, NJ: Merrill Education/Prentice Hall, Inc.

Council for Exceptional Children. (2008). Evidence-based practice. Retrieved October 15,2008 from http://www.cec.sped.org/AM/Template.cfm?Section=CEC_Today1\&TEMPLAT $\mathrm{E}=/ \mathrm{CM} /$ ContentDisplay.cfm\&CONTENTID $=6515$

Cradler, J., \& Cradler, R. (2002). NCLB poses challenges. Learning and Leading with Technology, 30(2), 46-57.

Crandall, W., Gerrey, W., \& Brabyn, J. (1994). Remote reading for visually impaired people: A new application for telecommunications. Technology and Disability, 3(3), 203-212.

Crane, C. M. (2005). Teacher perceived impact of technology on elementary classrooms and teaching [Abstract]. Doctoral dissertation, University of Missouri-Columbia. (WorldCat Dissertations No. 37276712) 
Davies, P. (1999). What is evidence-based education? British Journal of Educational Studies, 47, 108-121.

Day, J. N., \& Huefner, D. S. (2003). Assistive technology: Legal issues for students with disabilities and their schools. Journal of Special Education Technology, 18(2), 23-35.

Derer, K., Polsgrove, L., \& Rieth, H. (1996). A survey of assistive technology applications in schools and recommendations for practice. Journal of Special Education Technology, 13(2), 62-72.

Dissinger, F. (2003). Core curriculum in assistive technology: In-service for special educators and therapists. Journal of Special Education Technology, 18(2), 35-45.

Dugger, W. (1999). Putting technology education standards into practice. NASSP Bulletin, 83(608), 57-63.

Education Week. (2006). Technology Counts '06: The Information Edge. Retrieved March 26, 2007, from http://www.edweek.org/ew/articles/2006/05/04/35intro.h25.html?print=1

Education World (2008). National Standards: Table of Contents. Retrieved October 6, 2008, from http://www.education-world.com/standards/national/toc/index.shtml

Edyburn, D. (2005). Special education technology competencies. Special Education Technology Practice, 7(1), 16-27.

Edyburn, D. L. (2000). 1999 in review: A synthesis of the special education technology literature.[Electronic version]. Journal of Special Education Technology, 15(1), 1-7.

Edyburn, D. L. (2002a). 2001 in review: A synthesis of the special education technology literature.[Electronic version]. Journal of Special Education Technology, 17(2), 1-20.

Edyburn, D. L. (2002b). Aligning technology and standards. Special Education Technology Practice, 4 (4), 18-22.

Edyburn, D. L. (2003). 2002 in review: A synthesis of the special education technology literature.[Electronic version]. Journal of Special Education Technology, 18(3), 1-21.

Edyburn, D. L. (2004). 2003 in review: A synthesis of the special education technology literature.[Electronic version]. Journal of Special Education Technology, 19(4), 1-21. 
Edyburn, D. L., \& Gardner, J. E. (1999). Integrating technology into special education teacher preparation programs: Creating shared visions. Journal of Special Education Technology, 14(2), 3-17.

Elmore, R. F., \& Fuhrman, S. H. (1995). Opportunity-to-learn standards and the state role in education. Teachers College Record, 96(3), 432-457.

Englert, C. S., Manalo, M., \& Zhao, Y. (2004). I can do it better on the computer: The effects of technology-enabled scaffolding on young writers' composition. Journal of Special Education Technology, 19 (1), 5-21.

Erickson, F., \& Gutierrez, K. (2002). Culture, rigor, and science in educational research. Educational Researcher, 31(8), 21-24.

Ertmer, P. A., Conklin, D., \& Lewandowski, J. (2001). Increasing preservice teachers' capacity for technology integration through use of electronic models. (ERIC Document Reproduction Service No. ED470081)

Falk, B. (2002). Standards-based reforms: Problems and possibilities. Phi Delta Kappan, 83 (8), 612-620.

Feyerer, E., Miesenberger, K., \& Wohlart, D. (2002). ICT and assistive technology in teachers' education and training [Electronic version]. Lecture Notes in Computer Science, (2398), 107-114.

Fisher, M. (1998). Design your future: Technology literacy competency recommendations for K-12 education. Journal of Educational Technology Systems, 26 (1), 27-34.

Fitzgerald, G. E., Hardin, L., \& Hollingsead, C. (1997). Engaging preservice teachers in hypermedia authoring: Process and outcomes. Journal of Educational Computing Research, 16(2), 191-207.

Flowers, C. P., \& Algozzine, R. F. (2000). Development and validation of scores on the Basic Technology Competencies for Educators Inventory. Educational and Psychological Measurement, 60(3), 411-418.

Franklin, T. J. (2000). Predictors of Ohio K-4 student competencies on the national educational technology standards. (ERIC Document Reproduction Service No. ED449168)

Gooler, D., Kautzer, K., \& Knuth, R. (2000). Teacher Competence in Using Technologies: The Next Big Question. Honolulu, HA: Pacific Resources for Education and Learning. (ERIC Document Reproduction Service No. ED452175) 
Haas, J. (1995). Standards, assessments, and students: Encouraging both equity and excellence. NASSP Bulletin, 79(573), 95-101.

Hammel, J., \& Angelo, J. (1996). Technology competencies for occupational therapy practitioners. Assistive Technology, 8(1), 34-42.

Hammersley, M. (1997). Educational research and a response to David Hargreaves. British Educational Research Journal, 23(2), 141-161.

Hammersley, M. (2005). The myth of research-based practice: The critical case of educational inquiry. International Journal of Social Research Methodology, 8(4), 317-328.

Hargreaves, D. H. (1997). In defence of research for evidence-based teaching: A rejoinder to Martyn Hammersley. British Educational Research Journal, 23(1), 405-418.

Hargreaves, D. H. (1999). Revitalizing educational research: Lessons from the past and proposals for the future. Cambridge Journal of Education, 29(2), 239-249.

Hasselbring, T. S., \& Glaser, C. H (2000). Use of computer technology to help students with special needs. Future of Children, 10 (2), 102-22.

Hawsawi, A. M. B. (2002). Teachers' perceptions of computer technology competencies: Working with students with mild cognitive delay [Abstract]. Doctoral dissertation, University of Idaho. (ProQuest Pub. No. AAT 3080259)

Hayes, L. S. (2004). Methods used to determine technology competence for Virginia teachers [Abstract]. Doctoral dissertation, Virginia Polytechnic Institute and State University. (WorldCat Dissertations No. 62110880)

Heise, M. (1995). The courts vs. educational standards. Public Interest, (120), 55-63.

Heller, J., Steiner, C., Hockemeyer, C., \& Albert, D. (2006). Competence-based knowledge structures for personalised learning.[Electronic version]. International Journal on E-Learning, 5(1), 75-88.

Higgins, E. L., \& Raskind, M. H. (2005). The compensatory effectiveness of the Quicktionary Reading Pen II on the reading comprehension of students with learning disabilities. [Electronic version]. Journal of Special Education Technology, 20(1), 31-41.

Hill, K. (2003). AAC assessment: Applying evidence-based practice. Closing the Gap, 22(4), 1-12-13, 15. 
Hirumi, A., \& Grau, I. I. (1996). A review of computer-related state standards, textbooks, and journal articles: Implications for preservice teacher education and professional development. Journal of Computing in Teacher Education, 12(4), 617.

Hitchcock, C. (2001). Balanced instructional support and challenge in universally designed learning environments. Journal of Special Education Technology, 16(4), 23-30.

Hutinger, P., Johanson, J., \& Stonburner, R. (1996). Assistive technology applications in educational programs of children with multiple disabilities: A case study report on the state of the practice. Journal of Special Education Technology, 13(1), 1635.

Ingvarson, L. (1998). Professional development as the pursuit of professional standards: The standards-based professional development system. Teaching and Teacher Education, 14(1), 127-140.

International Society for Technology in Education. (2007). The NETS Project. Retrieved January 25, 2007, from http://cnets.iste.org/nets_overview.html

Jeffs, T., \& Morrison, W. F. (2005). Special education technology addressing diversity: A synthesis of the literature. Journal of Special Education Technology, 20(4), 19-25.

Jewell, M. (2007). No Child Left Behind: Implications for Special Education Students and Students with Limited English Proficiency. Retrieved September 9, 2007, from http://www.newhorizens.org/spneeds/improvement/jewell.htm

Johnston, S. S., \& Evans, J. (2005). Considering response efficiency as a strategy to prevent assistive technology abandonment. Journal of Special Education Technology, 20 (3), 45-50.

Kankaanranta, M. (2001). Constructing digital portfolios: Teachers evolving capabilities in the use of information and communications technology.[Electronic version]. Teacher Development, 5(2), 259-275.

Kanny, E. M., \& Anson, D. K. (1998). Current trends in assistive technology education in entry-level occupational therapy curriculum. The American Journal of Occupational Therapy, 52(7), 586-592.

Kelley, M., Wetzel, K., Padgett, H., Williams, M. K., \& Odom, M. (2004). Early childhood teacher preparation and technology integration: The Arizona State University West experience. Information Technology in Childhood Education Annual, 245-260. 
Kemp, L. E. (2000). Research in teacher education. Technology competencies in teacher education: An evaluation to guide implementation of beginning teacher technology competencies. (ERIC Document Reproduction Service No. ED442797)

Kim-Rupnow, W. S., \& Burgstahler, S. (2004). Perceptions of students with disabilities regarding the value of technology-based support activities on postsecondary education and employment. Journal of Special Education Technology, 19(1), 43-56.

King, K. P. (2002). A journey of transformation: A model of educators' learning experiences in educational technology. (ERIC Document Reproduction Service No. ED472069)

Kirst, M. W. (1997). Politics of science education standards. Elementary School Journal, 97(4), 315-328.

Kittel, A., DiMarco, A., \& Stewart, H. (2002). Factors influencing the decision to abandon manual wheelchairs for three individuals with spinal cord injury. Disability and Rehabilitation, 24, (1/2/3), 106-114.

Kovar, J. (2001). Demonstrating teacher proficiency in the ISTE/NCATE technology competencies. Unpublished masters thesis, Hamline University.

Krueger, K., Hansen, L., \& Smaldino, S. (2000). Preservice teacher technology competencies: A model for preparing teachers of tomorrow to use technology. TechTrends, 44(3), 47-50.

Lahm, E. (2000). Special education technology: Defining the specialist. Special Education Technology Practice, 3(3), 22-27.

Lahm, E. (2003). Assistive technology specialists: Bringing knowledge of assistive technology to school districts. Remedial and Special Education, 24(3), 141-153.

Lahm, E., \& Nickels, B. (1999). Assistive technology competencies for special educators.[Electronic version]. Teaching Exceptional Children, 32(1), 56-63.

Lahm, E., \& Sizemore, L. (2002). Factors that influence assistive technology decisionmaking. Journal of Special Education Technology, 17(1), 15-25.

Lange, A. A., McPhillips, M., Mulhern, G., \& Wylie, J. (2006). Assistive software tools for secondary students with literacy difficulties. Journal of Special Education Technology, 21 (3), 13-22.

Lee, Y., \& Vail, C. O. (2005). Computer-based reading instructions for young children with disabilities. Journal of Special Education Technology, 20 (1), 5-18. 
Lemke, C. (2003). Standards for a modern world. Learning and Leading with Technology, 31(1), 6-21.

Lenker, J. A. (1998). Professional education programs in rehabilitation engineering and assistive technology. Technology and Disability, 9, 37-48.

Lenker, J. A., \& Paquet, V. L. (2004). A new conceptual model for assistive technology outcomes research and practice. Assistive Technology 16(1), 1-10.

Light, J. (1999). Do augmentative and alternative communication interventions really make a difference? The challenges of efficacy research. Augmentative and Alternative Communication, 15, 13-44.

Lindstrand, P. (2001). Parents of children with disabilities evaluate the importance of the computer in child development. Journal of Special Education Technology, $16(2), 43-52$.

Linn, R. L. (2000). Standards-based accountability: Ten suggestions (Policy brief No. 1). Los Angeles, CA: UCLA Center for the Study of Evaluation, Center for Research on Evaluation, Standards, and Student Testing.

Lohr, K. N. (1998). Grading articles and grading evidence: Issues for evidence-based practice activities. Paper presented at the Translating Evidence into Practice 1998, Washington, DC. Retrieved March 13, 2007, from http://www.ahrq.gov/clinic/trip1998/

Lowther, D., Bassoppo-Moyo, T., \& Morrison, G. (1998). Moving from computer literate to technologically competent: The next educational reform.[Electronic version]. Computers and Human Behavior, 14(1), 93-109.

Lunenburg, F., \& Irby, B. (1999). GOALS 2000 and integrated technology: A national status report of elementary and secondary school principals. Final results. Washington, DC: U.S. Department of Education.

MacArthur, C. A. \& Cavalier, A. R. (2004). Dictation and speech recognition technology as test accommodations. Exceptional Children, 71 (1), 43-58.

MacArthur, C. A., Graham, S., Haynes, J. A., \& De La Paz, S. (1996). Spelling checkers and students with learning disabilities: Performance comparisons and impact on spelling. Journal of Special Education, 30, 35-57.

MacArthur, C. A., Haynes, J. A., Malouf, D. B., Harris, K., \& Owings, M. (1990). Computer assisted instruction with learning disabled students: achievement, engagement, and other factors that influence achievement. Journal of Educational Computing Research, 6 (3), 311-328. 
Mann, D., Shakeshaft, C., Becker, J., \& Kottkamp, R. (1998). West Virginia story: Achievement gains from a statewide comprehensive instructional program. Santa Monica, CA: Milken Exchange on Educational Technology.

Maushak, N. J., Kelley, P., \& Blodgett, T. (2001). Preparing teachers for the inclusive classroom: A preliminary study of attitudes and knowledge of assistive technology. Journal of Technology in Teacher Education, 9(1), 419-431.

McNear, D. (2005). Aligning Braille literacy and assistive technology skills with ISTE educational technology standards. Closing the Gap, 23(5), 1-9.

McInerney, M., Riley, K., \& Osher, D. (1999). Technology to support literacy strategies for students who are deaf: Final report. American Institutes for Research: Washington, D.C.

Michaels, C., \& McDermott, J. (2003). Assistive technology integration in special education teacher preparation: Program coordinators' perceptions of current attainment and importance. Journal of Special Education Technology, 18(3), 2945.

Minnesota Department of Education. (2005). Learning Support: Assistive Technology. Retrieved August 22, 2007, from http://education.state.mn.us/MDE/Learning_Support/Special_Education/Evaluati on_Program $/ \mathrm{html}$

Mirenda, P., Turoldo, K., \& McAvoy, C. (2006). The impact of word prediction software on the written output of students with physical disabilities. Journal of Special Education Technology, 21(3), 5-12.

Murphy, C. (2000). Effective use of ICT by student teachers -- Is it improving? (ERIC Document Reproduction Service No. ED444549)

National Association of Elementary School Principals (2007). Is NCLB Leaving Special Education Students Behind? Retrieved September 9, 2007, from http://www.naesp.org/ContentLoad.do? contentId=1247

Nickels, B. (1999). Assistive technology competencies for special educators: A Delphi study. Unpublished doctoral dissertation, University of Kentucky.

Niederhouser, D. S., \& Lindstrom, D. L. (2006). Addressing the NETS for students through constructivist technology. Journal of Educational Computing Research, 34(1), 91-128.

North Dakota Department of Public Instruction. (1999). Assistive Technology for Students with Disabilities. Retrieved August 22, 2007 from http://www.dpi.state.nd.us/speced/guide/assist.pdf 
Odom, S. L., Brantlinger, E., Gersten, R., Horner, R. H., Thompson, B., \& Harris, K. R. (2005). Research in special education: Scientific methods and evidence-based practices. Exceptional Children, 71(2), 137-148.

Osguthorpe, R. T., Osguthorpe, R. D., Jacob, W. J., \& Davies, R. (2003). The moral dimensions of instructional design. Educational Technology Research and Development, 43(2), 19-23.

O'Shea, L. J., Stoddard, K., \& O'Shea, D. J. (2000). IDEA-97 and educator standards: Special educators' perceptions of their skills and those of general educators. Teacher Education and Special Education, 23(2), 125-141.

Parette, H. P. (1997). Assistive technology devices and services. Education and Training in Mental Retardation and Developmental Disabilities, 32(4), 267-280.

Paulsen, K. J. (2005). Infusing evidence-based practices into special education preparation curriculum. Teacher Education and Special Education, 28 (1), 21-18.

Peck, K. (1998). Ready...fire...aim! Toward meaningful technology standards for educators and students. TechTrends, 43(2), 47-53.

Peck, K., Augustine, C., \& Popp, D. (2003). The AECT project: Modeling the effective use of technology in teacher preparation. TechTrends, 47(2), 21-23.

Perie, M., Moran, R., \& Lutkus, A. D. (2005). NEAP 2004 trends in academic progress: Three decades of student performance in reading and mathematics (Statistical analysis No. NCES 20005464). Washington, DC: National Center for Educational Statistics. Retrieved May 21, 2007, from http://nces.ed.gov/pubsearch/pubsinfo.asp?pubid=2005464

Persichitte, K. A., Caffarella, E. P., \& Ferguson-Pabst, D. (2003). A continuing journey toward technology infusion within teacher preparation. TechTrends, 47(2), 12-14.

Peterson, W. (1998). Public policy affecting universal design. Assistive Technology, $10(1), 13-20$.

Pettenati, M. C., Giuli, D., \& Khaled, O. A. (2001). Information technology and staff development: Issues and problems related to new skills and competence acquisition.[Electronic version]. Journal of Technology and Teacher Education, 9(2), 153-169.

Phelps, R., Hase, S., \& Ellis, A. (2005). Competency, capability, complexity and computers: Exploring a new model for conceptualising end-user computer education.[Electronic version]. British Journal of Educational Technology, 36(1), 67-84. 
Phillips, B., \& Zhao, H. (1993). Predictors of assistive technology abandonment. Assistive Technology, 5, 31-44.

Pierce, B. (2006). Assistive Technology in the State of Indiana. Retrieved September 15, 2007, from http://www.ittatc.org/training/jan26/State_of_Indiana.php

Pisha, B., \& Stahl, S. (2005). The promise of new learning environments for students with disabilities. Intervention in School and Clinic, 41(2), 67-75.

Pliner, S. M., \& Johnson, J. R. (2004). Historical, theoretical, and foundational principles of universal instructional; design in higher education. Equity \& Excellence in Education, 37(1), 105-113.

Puckett, K. S. (2004). Project ACCESS: Field testing an assistive technology toolkit for students with mild disabilities. Journal of Special Education Technology, 19(2), 5-19.

QIAT Consortium Leadership Team. (2000). Quality indicators for assistive technology services in school settings. Journal of Special Education Technology, 15(4), 25-36.

Raizen, S. A. (1998). Standards for Science Education. Teachers College Record, 100(1), 66-121.

Raskind, M. H., \& Higgins, E. (1995). Effects of speech synthesis on the proofreading efficiency of postsecondary students with learning disabilities. Learning Disability Quarterly, 18 (2), 141-158.

Reigeluth, C. M. (1997). Educational standards: To standardize or to customize learning? [Electronic version]. Phi Delta Kappan. Retrieved October 6, 2008, at http://www.indiana.edu/ iweb/reigeluth/kappan.rtf

Riemer-Reiss, M. L., \& Wacker, R. R. (2000). Factors associated with assistive technology discontinuance among individuals with disabilities. Journal of Rehabilitation, 66(1), 44-50.

Riley, G., Beard, L. A., \& Strain, J. (2004). Assistive technology at use in the teacher education programs at Jacksonville State University. TechTrends, 48(6), 47-50.

Ripat, J., \& Strock, A. (2004). Users' perceptions of the impact of electronic aids to daily living throughout the acquisition process. Assistive Technology, 16(1), 6372.

Roblyer, M. D. (2000). The national educational technology standards (NETS): A review of definitions, implications, and strategies for integrating NETS into k-12 curriculum. International Journal of Instructional Media, 27(2), 133-146. 
Rosenfeld, B., \& Martinez-Pons, M. (2004). Engendering technology use in the classroom (Research report). Chicago, IL: Association for Educational Communications and Technology. (ERIC Document Reproduction Service No. ED484989)

Rowley, B. A., Mitchell, D. F., \& Weber, C. (1997). Educating the rehabilitation engineer as a service provider. Assistive Technology, 9, 62-69.

Ryan, T. (2007). Assistive Technology: Maryland Teacher Technology Standards. Retrieved September 15, 2007, from http://pages.towson.edu/pryan/at/standard.htm

Sackett, D. L., Richardson, W. S., Rosenberg, W., \& Haynes, R. B. (1997). Evidencebased medicine: How to practice and teach EBM. New York: Churchill Livingstone.

Sackett, D. L., Rosenberg, W. M. C., Gray, J. A. M., Haynes, R. B., \& Richardson, W. S. (1996). Evidence based medicine: What it is and what it isn't. British Medical Journal, 312, 71-72.

Samuels, C. A. (2007). State Groups Use NCLB Reauthorization to Raise Special Education Concerns. Retrieved September 9, 2007, from http://www.edweek.org/ew/articles/2007/09/26/05special.h27.html?print=1

San Diego State University. (2007). Encyclopedia of Educational Technology. Retrieved April 11, 2007, from http://coe.sdsu.edu/eet

Sanderson, I. (2003). Is it 'what works' that matters? Evaluation and evidence-based policy-making. Research Papers in Education, 18(4), 331-345.

Sandholtz, J. H., \& Reilly, B. (2004). Teachers, not technicians: Rethinking technical expectations for teachers. Teachers College Record, 106(3), 487-512.

Sax, C., Fisher, D., \& Pumpian, I. (1996). Outcomes for students with severe disabilities: Case studies on the use of assistive technology in inclusive classrooms. Technology and Disability, 5, 327-334.

Schlosser, R. W., \& Raghavendra, P. (2004). Evidence-based practice in augmentative and alternative communication. Augmentative and Alternative Communication, 20(1), 1-21.

Schrag, J., \& Ahearn, E. M. (1998). Summary of changes related to the Individualized Education Program (IEP): Current law and 1997 IDEA Amendments, including congressional committee comments (Final Report). Alexandria, VA: National Association of State Directors of Special Education. (ERIC Document Reproduction Service No. ED416618) 
Sheldon, K. M., \& Biddle, B. J. (1998). Standards, accountability and school reform: Perils and pitfalls. Teachers College Record, 100(1), 164-180.

Silver, P., Bourke, A. B., \& Strehorn, K. C. (1998). Universal instructional design in higher education: An approach for inclusion. Equity \& Excellence in Education, $31(2), 47-51$.

Slavin, R. E. (2002). Evidence-based educational policies: Transforming educational practice and research. Educational Researcher, 31(7), 15-21.

Smith, S. (2000). Teacher education. Journal of Special Education Technology, 15(3), $39-40$.

Smith, S. J., \& Jones, E. (1999). Special education - The obligation to provide assistive technology: Enhancing general curriculum access. Journal of Law and Education, 28(2), 247-268.

Snell, M. E., Caves, K., McLean, L., Mollica, B. M., Mirenda, P., Paul-Brown, D., et al. (2003). Concerns regarding the application of restrictive "eligibility" policies to individuals who need communication services and supports: A response by the National Joint Committee for the Communication Needs of Persons with Severe Disabilities. Research and Practice for Persons with Severe Disabilities, 28(2), 70-78.

Soto, G., Muller, E., Hunt, P., \& Goetz, L. (2001). Critical issues in the inclusion of students who use augmentative and alternative communication: An educational team perspective. Augmentative and Alternative Communication, 17, 62-72.

Spitzer, D. R. (2003). Lessons learned: 20 keys to successful training and performance improvement. Educational Technology, 43(1), 50-53.

Stoner, M. L., Esterbrooks, S. R., \& Laughton, J. M. (2005). Handwritten and wordprocessed story telling by school-aged students who are deaf. [Electronic version]. Journal of Special Education Technology, 20(3), 35-45.

Stuhlmann, J. M., \& Taylor, H., G. (1999). Preparing technically competent student teachers: A three year study of interventions and experiences. Journal of Technology and Teacher Education, 7(4), 333-350.

Sutton, R. E. (1991). Equity and computers in the schools: A decade of research. Review of Educational Research, 61(4), 475-503.

Swain, C., \& Pearson, T. (2003). Educators and technology standards: Influencing the digital divide. Journal of Research on Technology in Education, 34(3), 326-335. 
Sweeny, B. (1999). Content standards: Gate or bridge. [Electronic version]. Kappa Delta Pi Record, 35(2), 1-5. Retrieved March 4, 2007, from hwwilsonweb database.

Thomas, L. G., \& Knezek, D. G. (2002). Standards for technology-supported learning environments. The State Education Standard, (Summer), 14-20.

Thompson, S., Lazarus, S., Clapper, A., \& Thurlow, M. (2004). Essential knowledge and skills needed by teachers to support the achievement of students with disabilities. EPRRI Issue Brief Five. College Park, MD: Educational Policy Reform Research Institute.

Tindal, G., Heath, B., Hollenbeck, K., Almond, P., \& Harniss, M. (1998).

Accommodating students with disabilities on large-scale tests: An experimental study. Exceptional Children, 64(4), 439-450.

Todis, B. (1996). Assistive technology in educational settings. Journal of Special Education Technology, 13 (2), 49-61.

Topper, A. (2004). How are we doing? Using self-assessment to measure changing teacher technology literacy within a graduate educational technology program. Journal of Technology and Teacher Education, 12(3), 303-317.

Treviranus, J., \& Coombs, N. (2000). Bridging the digital divide in higher education (Technical report). Reston, VA: Council for Exceptional Children. (ERIC Document Reproduction Service No. ED452812)

Tumlin, J. \& Heller, K., W, (2004). Using word prediction software to increase typing fluency with students with disabilities. Journal of Special Education Technology, 19(3), 1-22. Retrieved August 21, 2008, from http://jset.unlv.edu/19.3/tumlin/tumlin.pdf

U.S. Department of Education (2006). Secretary's Fifth Annual Report on Teacher Quality. Retrieved September 15, 2007, from http://www.ed.gov/about/reports/annual/teachprep/2006-title2report.pdf

U.S. Department of Education (2007a). Consolidated State Performance Reports. Retrieved September 22, 2007, from http://www.ed.gov/admins/lead/account/consolidated/index.html

U.S. Department of Education (2007b). FY 2006 Performance and Accountability Report. Retrieved September 9, 2007, from http://www.ed.gov/about/reports/annual/2006report/index.html 
U.S. Department of Education (2007c). Guidance on Standards, Assessments, and Accountability. Retrieved September 9, 2007 from http://www.ed.gov/print/policy/elsec/guid/standardsassessment/guidance.html

U.S. Department of Education (2008). National Assessment of Educational Progress (NAEP), National Center for Educational Statistics (NCES), Institute of Educational Sciences. Retrieved September 20, 2008, from http://nces.ed.gov/nationsreportcard/

U.S. Department of Justice (2007). Information and Technical Assistance on the Americans with Disabilities Act: ADA Homepage. Retrieved August 25, 2007, from http://www.usdoj.gov/crt/ada/adahom.1.htm

U.S. Department of Justice. (2000). Information technology and people with disabilities: the current state of federal access (Policy paper No. J 1.2: D 63/4). Washington, DC: U.S. Department of Justice. Retrieved September 11, 2006, from http://purl.access.gpo.gov/GPO/LPS70255

U.S. Department of Labor (2007a). Employment Standards Administration: Section 503 of the Rehabilitation Act of 1973. Retrieved August 25, 2007, from http://www.dol.gov/esa/regs/compliance/ofccp/fs503.htm

U.S. Department of Labor (2007b). Employment Standards Administration: Section 504 of the Rehabilitation Act of 1973. Retrieved August 25, 2007, from http://www.dol.gov/esa/regs/compliance/ofccp/fs504.htm

U.S. House Committee on Education and the Workforce. (2004). Improving access to assistive technology for Individuals with Disabilities Act of 2004 (Legislative report No. Y 1.1/8:108-514). Washington, DC: US House of Representatives. Retrieved September 11, 2006, from http://purl.access.gpo.gov/GPO/LPS51142

Waddoups, G. L., Wentworth, N., \& Earle, R. (2004). Principles of technology integration and curriculum development: A faculty design team approach. Computers in the Schools, 21(1), 15-23.

Warger, C. L. (1998). Integrating assistive technology into the standard curriculum. Reston, VA: Council for Exceptional Children. (ERIC Document Reproduction Service No. ED426517)

Waugh, M., Levin, J., \& Buell, J. (1999). The technology competencies database: Computer support for assessment, teaching, and portfolio management. Journal of Technology and Teacher Education, 7(4), 351-363.

Weber, A. (1998). Credentialing in assistive technology. Technology and Disability, 9, 59-63. 
Whitehurst, G. (2003). The Institute of Education Sciences: New wine, new bottles [Electronic version]. Retrieved November 21, 2006, from http://www.ed.gov/offices/IES/speeches/evidencebase.html

Wiebe, J. A., Taylor, H. G., \& Thomas, L. G. (2000). The national educational technology standards for PK-12 students: Implications for teacher education. Journal of Computing in Teacher Education, 16 (3), 12-17.

Williams, S. C. (2002). How speech-feedback and word-prediction software can help students write. TEACHING Exceptional Children, 34 (3), 72-28.

Wilson, J. M. (2003). Protocol and training of educators for the use of technology to enhance learning in Tennessee certified schools [Abstract]. Doctoral dissertation, University of Tennessee, Knoxville. (WorldCat Dissertations No. 53114407)

Zabala, J. (1995). The SETT framework: Critical areas to consider when making informed assistive technology decisions. (ERIC Document Reproduction Service No. ED381962)

Zabala, J., Blunt, M., Carl, D., Davis, S., Deterding, C., Foss, T., et al. (2000). Quality Indicators for Assistive Technology Services in the Schools.[Electronic version]. Journal of Special Education Technology, 15(4), 25-36.

Zabala, J. S., \& Carl, D. F. (2004). Introduction to the QIAT Self-evaluation matrices. Topics in Language Disorders, 24(1), 39-49. 